University of Tennessee Health Science Center UTHSC Digital Commons

\title{
$5-2011$
}

\section{Activity of Epithelial Defensin HBD-3 Against a Periodontal Pathogen}

\author{
Norman B. Fine \\ University of Tennessee Health Science Center
}

Follow this and additional works at: https://dc.uthsc.edu/dissertations

Part of the Periodontics and Periodontology Commons

\section{Recommended Citation}

Fine, Norman B. , "Activity of Epithelial Defensin HBD-3 Against a Periodontal Pathogen" (2011). Theses and Dissertations (ETD). Paper 81. http://dx.doi.org/10.21007/etd.cghs.2011.0093. 


\title{
Activity of Epithelial Defensin HBD-3 Against a Periodontal Pathogen
}

\begin{abstract}
Defensins are cationic (positive-charged) peptides with broad-spectrum antibiotic activity. In humans, there are two types of defensins, alpha $(\alpha)$ and beta $(\beta)$. Human neutrophils contain four $\alpha$-defensins known as Human Neutrophil Peptide (HNP) 1-4. Epithelial cells produce four $\beta$-defensins known as Human Beta Defensin (HBD) 1-4. Gram-negative anaerobic bacteria that are associated with periodontal disease are resistant to human $\alpha$-defensins, but are killed by $\beta$-defensins.
\end{abstract}

HBD-3 is the most active $\beta$-defensin. HBD-3 is a longer peptide than HNP 1-4. HBD-3 has additional amino acid residues with hydrophobic side chains near the $\mathrm{N}$-terminus and residues with cationic side chains at the C-terminus.

Objectives: (1) Confirm that the periodontal pathogen A.a. (Aggregatibacter actinomycetemcomitans) is resistant to HNP-1 but killed by HBD-3; (2) Determine if the N-terminal or C-terminal portion of HBD-3 can account for activity against A.a.; (3) Determine whether HBD-3 binds to lipopolysaccharide (LPS), which covers the surface of gram-negative bacteria; (4) Determine whether binding of the hydrophobic $\mathrm{N}$ terminus of HBD-3 to the hydrophobic lipid A portion of LPS accounts for activity of HBD-3 against A.a.

Methods: Non-pathogenic Escherichia coli and pathogenic A.a. Y4 bacteria were incubated with recombinant HBD-3 or HNP-1 purified from human neutrophils. Bacteria were also incubated with synthetic peptides CHRG07 and CHRG01. These peptides have sequences derived from the HBD-3 Nterminus and $\mathrm{C}$-terminus, respectively. The number of viable bacteria was determined by diluting, plating on solid growth medium, and counting colonies.

Bacteria were also incubated with HBD-3 and purified LPS from E. coli or A.a. to determine whether purified LPS absorbs HBD-3 and blocks killing. Similar experiments used purified lipid A or deacylatedLPS, which lacks the hydrophobic fatty acids of the lipid Aportion of LPS.

Results: HBD-3 had strong bactericidal activity against A.a. under the usual assay conditions for $\alpha$ defensins (in dilute culture medium) and the usual assay conditions for $\beta$-defensins (in buffer without nutrients). HBD-3 at $5 \mu \mathrm{M}$ gave 90 to $99 \%$ killing of $A$.a.within 2 to $4 \mathrm{~h}$. In contrast, HNP-1 had no activity against $A$.a. regardless of assay conditions, confirming that $A$.a. is resistant to HNP-1 but killed by HBD-3.

Both CHRG07 and CHRG01 killed A.a., but CHRG07 was much more active. The activity of CHRG07 was equal to that of HBD-3, indicating that the mixture of hydrophobic and cationic amino acid residues at the $\mathrm{N}$-terminus can account for HBD-3 activity against $A$.a.

Purified LPS from E. coli or A.a. blocked the activity of HBD-3 at a 1:1 ratio of LPS to HBD-3, indicating that one molecule of HBD-3 binds to each molecule of LPS. Deacylated-LPS also blocked HBD-3 at a 1:1 ratio, but purified lipid A did not block. Although HBD-3 binds to LPS, and hydrophobic residues near the $\mathrm{N}$-terminus of HBD-3 appear to be important for killing of A.a., the hydrophobic lipid A portion of LPS was not the binding site for HBD-3. Binding of HBD-3 to other hydrophobic substances such as membrane proteins or phospholipids may be important to HBD-3 activity against $A$.a.

Conclusions: Resistance of $A$.a. to leukocyte $\alpha$-defensins is probably important to the ability of $A$.a. to cause disease. On the other hand, the epithelial cell $\beta$-defensins probably help to protect healthy individuals against oral disease. Small synthetic peptides such as CHRG07 that contain the portion of HBD-3 active against the periodontal pathogen A.a. may be useful to prevent or treat gingivitis and periodontitis. 


\section{Document Type}

Thesis

\section{Degree Name}

Master of Dental Science (MDS)

\section{Program}

Periodontology

\section{Research Advisor}

Edwin L. Thomas, Ph.D.

\section{Keywords}

Defensin, Epithelium, Lipopolysaccharide

\section{Subject Categories}

Dentistry | Medicine and Health Sciences | Periodontics and Periodontology 


\title{
ACTIVITY OF EPITHELIAL DEFENSIN HBD-3 AGAINST A PERIODONTAL PATHOGEN
}

\author{
A Thesis \\ Presented for \\ The Graduate Studies Council \\ The University of Tennessee \\ Health Science Center
}

\author{
In Partial Fulfillment \\ Of the Requirements for the Degree \\ Master of Dental Science \\ From The University of Tennessee
}

By

Norman B. Fine

May, 2011 
Copyright (C 2011 by Norman B. Fine.

All rights reserved. 


\section{DEDICATION}

I dedicate this thesis to my loving wife, Amy E. Fine, and my family for their continuous love and support. 


\section{ACKNOWLEDGMENTS}

I would like to thank Dr. Edwin L. Thomas for his dedication and commitment towards mentoring me throughout this master's thesis project. It's been an honor and privilege to have been mentored by such a great individual and to be a part of a group so enthusiastic about research and education. I will not be able to thank him enough for the time and effort spent with me in order to make this project possible.

I would like to thank my Committee members Drs. Pradeep Adatrow, Anastasios Karydis, Swati Rawal, and Sidney Stein for their support and valuable suggestions. I would also like to thank Dr. Paul S. Bland and the Department of Periodontology for allowing me this opportunity and accepting me into the graduate periodontal program.

I would like to express my sincere appreciation to Mary Margaret Jefferson for her help with lab work, literature reviews, and purifying the HNP-1 used in this study. I cannot thank her enough for her time, commitment and dedication to research and education.

I would like to thank Dr. Jegdish P. Babu for providing A.a. LPS. Without his help this project would have been impossible to achieve.

I also wish to thank the University of Tennessee College of Dentistry Alumni Endowment Fund for financial support of this project. 


\begin{abstract}
Defensins are cationic (positive-charged) peptides with broad-spectrum antibiotic activity. In humans, there are two types of defensins, alpha $(\alpha)$ and beta $(\beta)$. Human neutrophils contain four $\alpha$-defensins known as Human Neutrophil Peptide (HNP) 1-4. Epithelial cells produce four $\beta$-defensins known as Human Beta Defensin (HBD) 1-4. Gram-negative anaerobic bacteria that are associated with periodontal disease are resistant to human $\alpha$-defensins, but are killed by $\beta$-defensins.

HBD-3 is the most active $\beta$-defensin. HBD-3 is a longer peptide than HNP 1-4. HBD-3 has additional amino acid residues with hydrophobic side chains near the Nterminus and residues with cationic side chains at the $\mathrm{C}$-terminus.

Objectives: (1) Confirm that the periodontal pathogen A.a. (Aggregatibacter actinomycetemcomitans) is resistant to HNP-1 but killed by HBD-3; (2) Determine if the $\mathrm{N}$-terminal or C-terminal portion of HBD-3 can account for activity against A.a.; (3) Determine whether HBD-3 binds to lipopolysaccharide (LPS), which covers the surface of gram-negative bacteria; (4) Determine whether binding of the hydrophobic N-terminus of HBD-3 to the hydrophobic lipid A portion of LPS accounts for activity of HBD-3 against $A$.a.
\end{abstract}

Methods: Non-pathogenic Escherichia coli and pathogenic A.a. Y4 bacteria were incubated with recombinant HBD-3 or HNP-1 purified from human neutrophils. Bacteria were also incubated with synthetic peptides CHRG07 and CHRG01. These peptides have sequences derived from the HBD-3 N-terminus and C-terminus, respectively. The number of viable bacteria was determined by diluting, plating on solid growth medium, and counting colonies.

Bacteria were also incubated with HBD-3 and purified LPS from E. coli or A.a. to determine whether purified LPS absorbs HBD-3 and blocks killing. Similar experiments used purified lipid A or deacylated-LPS, which lacks the hydrophobic fatty acids of the lipid A portion of LPS.

Results: HBD-3 had strong bactericidal activity against $A$. $a$. under the usual assay conditions for $\alpha$-defensins (in dilute culture medium) and the usual assay conditions for $\beta$-defensins (in buffer without nutrients). HBD-3 at $5 \mu \mathrm{M}$ gave 90 to $99 \%$ killing of $A$. $a$. within 2 to $4 \mathrm{~h}$. In contrast, HNP-1 had no activity against $A$. a. regardless of assay conditions, confirming that A.a. is resistant to HNP-1 but killed by HBD-3.

Both CHRG07 and CHRG01 killed A.a., but CHRG07 was much more active. The activity of CHRG07 was equal to that of HBD-3, indicating that the mixture of hydrophobic and cationic amino acid residues at the N-terminus can account for HBD-3 activity against $A$. $a$. 
Purified LPS from E. coli or A.a. blocked the activity of HBD-3 at a 1:1 ratio of LPS to HBD-3, indicating that one molecule of HBD-3 binds to each molecule of LPS. Deacylated-LPS also blocked HBD-3 at a 1:1 ratio, but purified lipid A did not block. Although HBD-3 binds to LPS, and hydrophobic residues near the N-terminus of HBD-3 appear to be important for killing of A.a., the hydrophobic lipid A portion of LPS was not the binding site for HBD-3. Binding of HBD-3 to other hydrophobic substances such as membrane proteins or phospholipids may be important to HBD-3 activity against $A$.a.

Conclusions: Resistance of A.a. to leukocyte $\alpha$-defensins is probably important to the ability of $A$. $a$. to cause disease. On the other hand, the epithelial cell $\beta$-defensins probably help to protect healthy individuals against oral disease. Small synthetic peptides such as CHRG07 that contain the portion of HBD-3 active against the periodontal pathogen A.a. may be useful to prevent or treat gingivitis and periodontitis. 


\section{TABLE OF CONTENTS}

CHAPTER 1: INTRODUCTION AND LITERATURE REVIEW . . . . . . . . 1

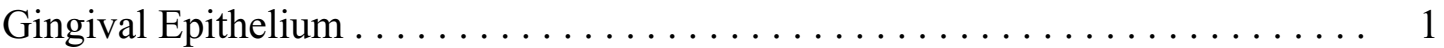

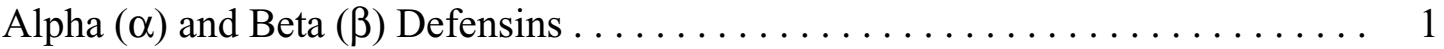

Defensins and Oral Health $\ldots \ldots \ldots \ldots \ldots \ldots \ldots \ldots \ldots \ldots \ldots \ldots \ldots$

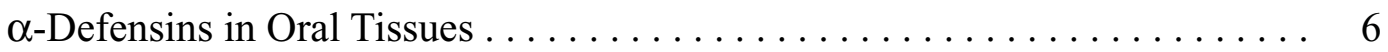

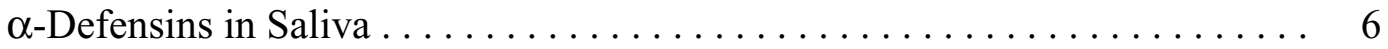

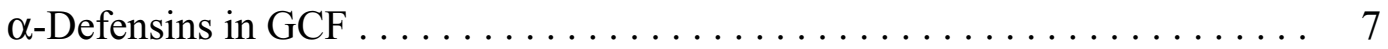

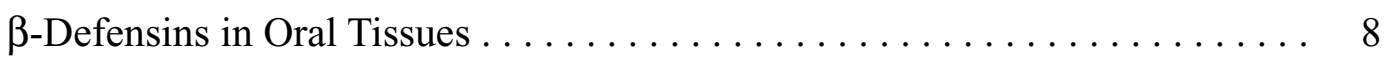

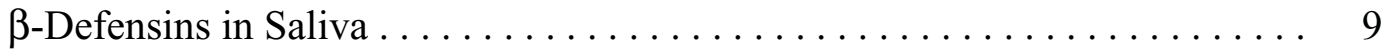

$\beta$-Defensins in GCF . . . . . . . . . . . . . . . . . . . . . . 9

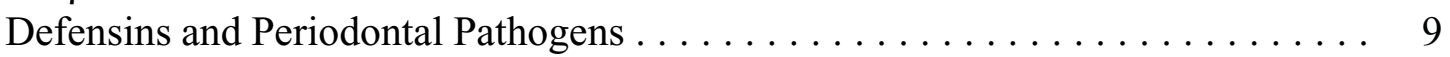

HBD-3 Structure and Antimicrobial Activity . . . . . . . . . . . . . 10

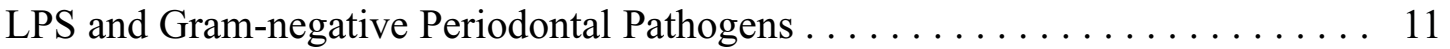

CHAPTER 2: SPECIFIC OBJECTIVES $\ldots \ldots \ldots \ldots \ldots \ldots \ldots \ldots \ldots \ldots$

CHAPTER 3: MATERIALS AND METHODS $\ldots \ldots \ldots \ldots \ldots \ldots \ldots \ldots$

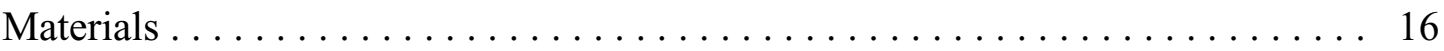

Chemicals . . . . . . . . . . . . . . . . . . . . . . . 16

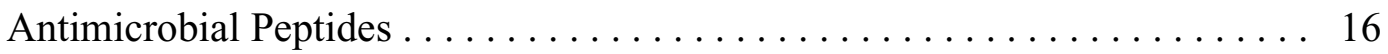

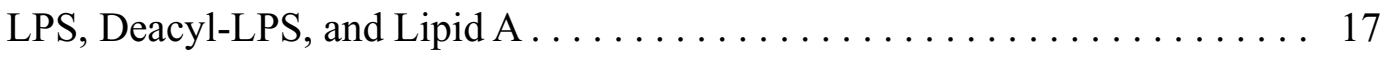

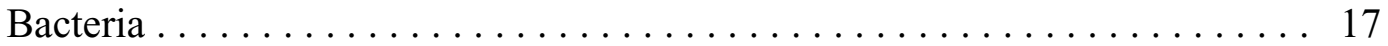

Methods .................................... 17

Bacterial Inocula . . . . . . . . . . . . . . . . . . . 17

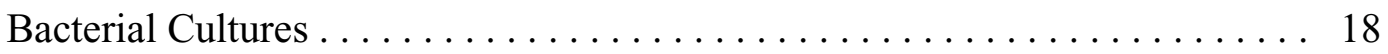

Antibacterial Assay . . . . . . . . . . . . . . . . . . . . . 18

Estimated Molecular Weights of LPS, Deacyl-LPS, and Lipid A . . . . . . . . 18

Data Analysis . . . . . . . . . . . . . . . . . . . . . . 19

CHAPTER 4: $\operatorname{RESULTS} \ldots \ldots \ldots \ldots \ldots \ldots \ldots \ldots \ldots \ldots \ldots \ldots \ldots$

Activity of HNP-1 and HBD-3 under Differing Assay Conditions . . . . . . . . 20

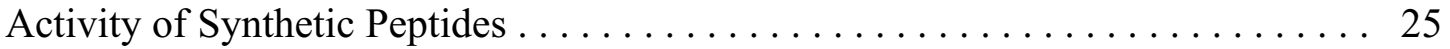

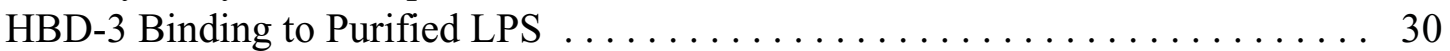

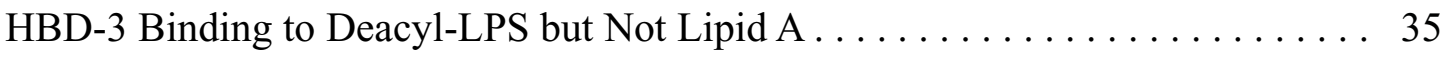

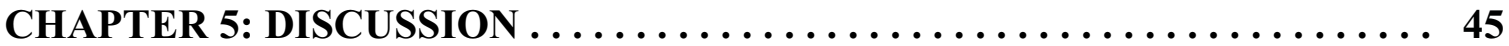

Effect of Assay Conditions on Activity of HBD-3 and HNP-1 . . . . . . . . . 45

Role of HBD-3 N- and C-terminal Regions in Antimicrobial Activity . . . . . . . . 45

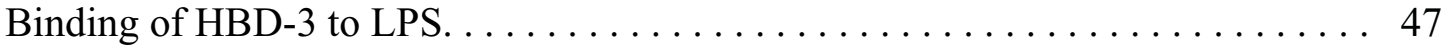

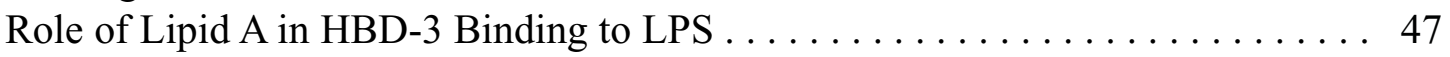

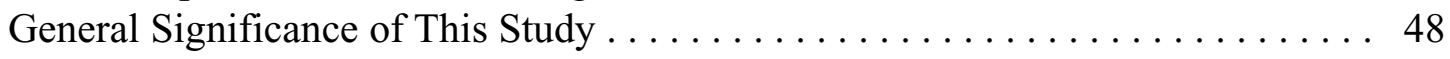

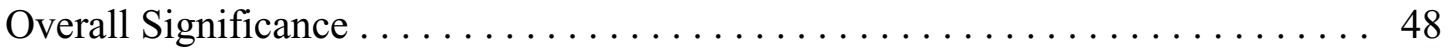




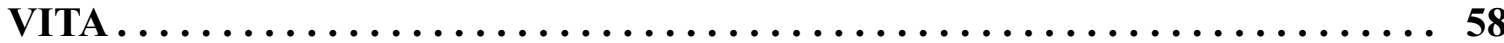




\section{LIST OF FIGURES}

Figure 1.1. Amino acid sequences of human leukocyte $\alpha$-defensins and epithelial cell $\beta$-defensins .............................. 3

Figure 1.2. Sequences of HNP-1 and HBD-3 $\ldots \ldots \ldots \ldots \ldots \ldots \ldots \ldots$

Figure 1.3. Sequences of HBD-3 and peptides CHRG07 and CHRG01 _... . 12

Figure 1.4. Representations of LPS, deacyl-LPS, and lipid A structures . . . . . 14

Figure 4.1. HNP-1 kills E. coli in dilute culture medium .............. 21

Figure 4.2. HBD-3 kills E. coli in dilute culture medium ................ 22

Figure 4.3. HNP-1 does not kill A.a. in dilute culture medium ........... 23

Figure 4.4. HBD-3 kills A.a. in dilute culture medium ............... 24

Figure 4.5. HNP-1 does not kill E. coli in buffer ................. 26

Figure 4.6. HBD-3 kills E. coli in buffer ...................... 27

Figure 4.7. HNP-1 does not kill A.a. in buffer ................... 28

Figure 4.8. HBD-3 kills A.a. in buffer ...................... 29

Figure 4.9. The peptide CHRG07 kills E. coli .................... 31

Figure 4.10. The peptide CHRG01 kills E. coli ................... 32

Figure 4.11. The peptide CHRG07 kills A.a. .................. 33

Figure 4.12. The peptide CHRG01 kills A.a.................... 34

Figure 4.13. E. coli LPS blocks HBD-3 killing of E. coli ................ 36

Figure 4.14. A.a. LPS blocks HBD-3 killing of E. coli. .............. 37

Figure 4.15. E. coli LPS blocks HBD-3 killing of A.a. .............. 38

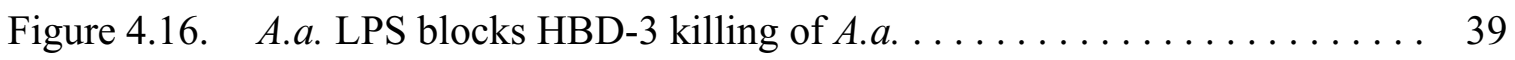

Figure 4.17. Deacyl-LPS blocks HBD-3 killing of E. coli . . . . . . . . . . . . . . 40 
Figure 4.18. Deacyl-LPS blocks HBD-3 killing of $A . a \ldots \ldots \ldots \ldots \ldots \ldots \ldots$

Figure 4.19. Lipid A does not block HBD-3 killing of E. coli. . . . . . . . . . 42

Figure 4.20. Lipid A does not block HBD-3 killing of $A . a . \ldots \ldots \ldots \ldots \ldots \ldots$ 


\section{LIST OF ABBREVIATIONS}

A.a.

ATCC

C. albicans

CAP

CFU

Deacyl-LPS

ELISA

E. coli

F.n.

GCF

GCSF

HBD

HNP

HPLC

$\mathrm{LC} / \mathrm{MS}$

LPS

MALDI-TOF

MS

$\mathrm{P}$

P.d.

P.g.

P.i.

S.E.

SELDI-TOF

S. mutans

TSB
Aggregatibacter (Actinobacillus) actinomycetemcomitans

American Type Culture Collection

Candida albicans

Cationic antimicrobial peptide

Colony forming units

Deacylated-lipopolysaccharide

Enzyme-linked immunosorbent assay

Escherichia coli

Fusobacterium nucleatum

Gingival crevicular fluid

Granulocyte colony stimuating factor

Human beta defensin

Human neutrophil peptide

High pressure liquid chromatography

Liquid chromatography/mass spectrometry

Lipopolysaccharide

Matrix-assisted laser desorption and ionization-time of flight

Mass spectrometry

Probability

Prevotella denticola

Porphyromonas gingivalis

Prevotella intermedia

Standard error

Surface-enhanced laser desorption and ionization-time of flight Streptococcus mutans

Trypticase soy broth 


\section{CHAPTER 1. INTRODUCTION AND LITERATURE REVIEW}

\section{Gingival Epithelium}

Epithelial cells are the first line of defense against microbial invasion. These cells cover the skin and mucosal tissues and protect the underlying tissues from invasion. Once this barrier is breached, infection and tissue destruction can occur. Periodontal disease is an example of the destructive properties of this microbial breach. Periodontal diseases are initiated by a breakdown of the bacteria-host equilibrium resulting in the inflammatory destruction of tooth-supporting tissues.

The oral cavity is a warm, moist environment where many species of commensal and pathogenic bacteria come into contact with mucosal tissues and the teeth. The oral cavity is unique in having a mucosal epithelium that is penetrated by the hard structures of the teeth. This gingival epithelium has specialized regions associated with the gingival tooth interface. The junctional epithelium forms a tight seal to the tooth and is adjacent to the gingival sulcus. A bacterial biofilm adheres to the tooth surface and comes into contact with the gingival epithelium in the gingival sulcus.

The oral mucosa is bathed in salivary secretions that play a complex role in the oral cavity. Salivary secretions contain mucins and many antimicrobial proteins and peptides. Mucins are glycoproteins secreted by the submandibular and sublingual salivary glands. Mucins form a viscous layer that protects the gingival epithelium from desiccation and mechanical, chemical and bacterial damage.

Neutrophils enter crevicular fluid at the gingival sulcus in response to chemotactic signals from bacterial products and cytokines released by leukocytes and epithelial cells. Neutrophils and other leukocytes defend epithelial cells against microbial damage by phagocytizing micro-organisms and releasing antimicrobial substances. Evidence for the importance of neutrophils in oral health comes from a number of congenital defects of neutrophil function that lead to severe periodontal disease in young patients $(1,2)$.

In addition to their barrier function, epithelial cells protect themselves and the underlying tissues by producing protective mucins, immune-regulating cytokines, and antimicrobial proteins and peptides.

\section{Alpha ( $\alpha)$ and Beta $(\beta)$ Defensins}

Cationic antimicrobial peptides (CAPs) are small, positively-charged peptides with broad-spectrum antibiotic activity. They kill gram-negative and gram-positive bacteria and fungi. CAPs are widely distributed in nature. They are found not only in humans and other vertebrates, but in plants and insects. In humans, CAPs include: 
- Alpha ( $\alpha$ )-defensins, found in neutrophils (polymorphonuclear leukocytes) and Paneth cells in the intestine.

- Beta $(\beta)$-defensins, found in epithelial cells of skin and mucosal tissues.

- Cathelicidin LL-37, produced by proteolytic cleavage of the CAP-18 protein in neutrophils and epithelial cells.

- Histatins, produced by the salivary glands.

$\alpha$-Defensins were the first to be discovered. There are four $\alpha$-defensins named HNP (human neutrophil peptide) 1-4 in human neutrophils $(3,4)$. The $\alpha$-defensins are major neutrophil components. There are more molecules of defensins than any other protein or peptide in neutrophils. Together they make up 6 to $7 \%$ of the total protein of the cell. Most studies of human $\alpha$-defensins have used HNP-1, which is the easiest to purify.

$\beta$-Defensins were discovered later. There are at least four $\beta$-defensins, named HBD (human beta defensin) 1-4, produced by epithelial cells in many tissues (5-8). HBD 1-3 have been detected in epithelial cells of the oral mucosa, gingival crevicular fluid (GCF), and saliva. HBD-3 was first isolated from psoriatic scales of skin (9) and was later found to be expressed in healthy and diseased skin, epithelial cells of the oral lining, and esophageal mucosa (10). HBD-4 has not been detected in oral tissues but is found in testicle, uterus and stomach (11).

$\beta$-Defensins are present in small amounts. It isn't possible to purify enough $\beta$ defensins from human tissues to study antimicrobial activity. Recently, $\beta$-defensins have been produced by two techniques - chemical synthesis and recombinant DNA technology. It's now possible to study antimicrobial activity using synthetic or recombinant $\beta$ defensins. Most studies have used HBD-3, which has the strongest activity against many of the micro-organisms that have been tested (11-13).

Figure 1.1 shows sequences (14) of the neutrophil $\alpha$-defensins HNP 1-4 and the epithelial cell $\beta$-defensins HBD 1-4. Because $\alpha$ - and $\beta$-defensins are products of different genes, they have different amino acid sequences. The common feature of $\alpha$ - and $\beta$-defensins is that they have six cysteine residues linked in three intra-molecular disulfide bonds. As seen in Figure 1.1, the position of the cysteine residues in the sequence is different in $\alpha$ - and $\beta$-defensins.

Table 1.1 summarizes physical properties of the $\alpha$ - and $\beta$-defensins. Human $\beta$ defensins are larger than $\alpha$-defensins. They have about the same number of amino acids with hydrophobic side chains, but have more amino acid residues with cationic side chains and a stronger net positive charge.

Figure 1.2 compares the amino acid sequences and disulfide linkages of HNP-1 and HBD-3. HNP-1 has 30 amino acid residues and a molecular weight of 3442. HBD-3 has 45 residues and a molecular weight of 5155. The cysteine residues are numbered 1 to 6 from the N-terminus. In $\alpha$-defensins, the disulfide linkages are 1-6, 2-4 and 3-5. In $\beta$ - 
HNP-1

HNP-2

HNP-3

HNP-4

HBD-1

HBD-2

HBD-3

HBD-4

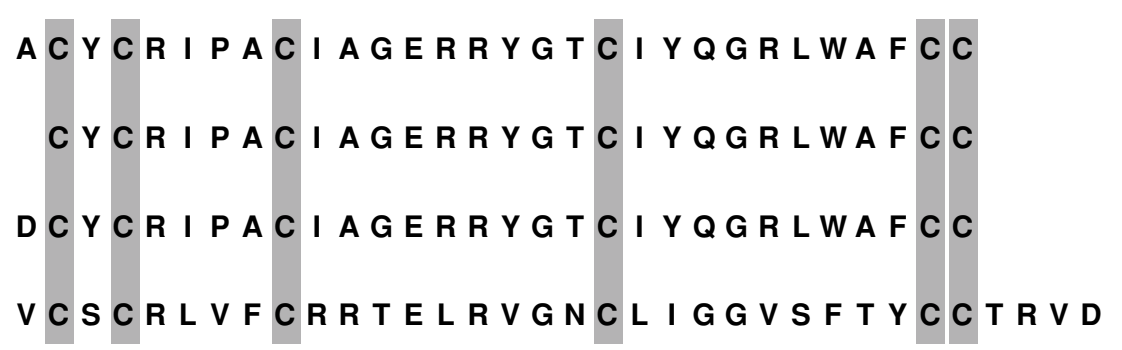

GNFLTGLGHRSDHYNCVSSGGQCLYSACPIFTKIQGTCYRGKAKCCK G I GDPVTCLKSGA I CHPVFCPRR YKQ I G TCGLPGTKCCKKP G I I NTLQKYYCRVRGGRCAVLSCLPKEEQ I GKCSTRGRKCCRRKK EFELDR I CGYGTARCRK - KCRSQEYR I GRCPN - T YACCLRKWDESLLNRTKP

Figure 1.1 Amino acid sequences of human leukocyte $\alpha$-defensins and epithelial cell $\beta$-defensins

Shaded areas indicate positions of the six conserved cysteine (C) residues. Spaces have been added to the HBD-4 sequence to improve alignment of the cysteine residues. 
Table 1.1. Summary of composition of HNP 1-4 and HBD 1-4

\begin{tabular}{ccccc}
\hline Defensin & $\begin{array}{c}\text { Total } \\
\text { residues }\end{array}$ & $\begin{array}{c}\text { Hydrophobic } \\
\text { residues }\end{array}$ & $\begin{array}{c}\text { Cationic } \\
\text { residues }\end{array}$ & $\begin{array}{c}\text { Net } \\
\text { charge }\end{array}$ \\
\hline HNP-1 & 30 & 9 & 4 & +3 \\
HNP-2 & 29 & 8 & 4 & +3 \\
HNP-3 & 30 & 8 & 4 & +2 \\
HNP-4 & 34 & 11 & 5 & +3 \\
HBD-1 & 47 & 10 & 8 & +7 \\
HBD-2 & 41 & 9 & 8 & +7 \\
HBD-3 & 45 & 9 & 13 & +11 \\
HBD-4 & 50 & 9 & 12 & +6 \\
\hline
\end{tabular}

Hydrophobic residues found in the peptides include alanine (A), isoleucine (I), leucine $(\mathrm{L})$, phenylalanine $(\mathrm{F})$, and valine $(\mathrm{V})$. Cationic residues include histidine $(\mathrm{H})$, lysine $(\mathrm{K})$, and arginine $(\mathrm{R})$. 
HNP-1

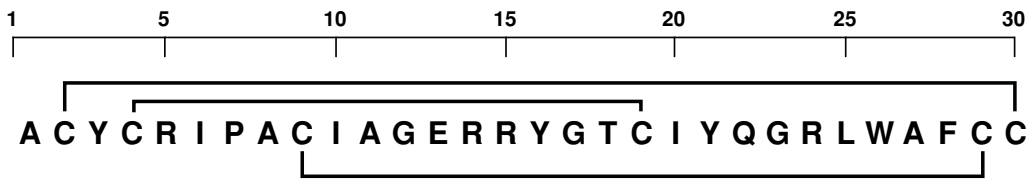

G I I NTLQKYYCRVRGGRCAVLSCLPKEEQIGKCSTRGRKCCRRKK

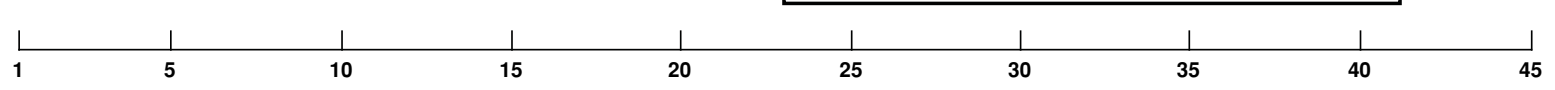

HBD-3

Figure 1.2 Sequences of HNP-1 and HBD-3

Lines indicate disulfide bonds between cysteine residues. 
defensins, the linkages are 1-5, 2-4 and 3-6. Therefore, the peptides are folded differently and have different 3-dimensional shapes $(15,16)$. Another difference is that HBD-3 has a higher positive charge. HNP-1 has four positively-charged arginine (R) residues and one negatively-charged glutamate $(\mathrm{E})$ residue, for a net charge of +3 . HBD-3 has seven arginine $(\mathrm{R})$ residues, six positively-charged lysine $(\mathrm{K})$ residues, and two glutamate $(\mathrm{E})$ residues for a net charge of +11 . The strong antimicrobial activity of HBD-3 may be due in part to its large net positive charge.

Another difference in the structures is that HBD-3 has additional residues at the $\mathrm{N}$-terminus and C-terminus. The N-terminal region of HBD-3 is hydrophobic, with two isoleucine (I) residues and one leucine (L) residue before the first cysteine. HNP-1 has only one hydrophobic residue, alanine (A) before the first cysteine. The $\mathrm{C}$-terminal region of HBD-3 is cationic, with two arginine $(\mathrm{R})$ and two lysine $(\mathrm{K})$ residues beyond the last cysteine. HNP-1 has no additional residues at the $\mathrm{C}$-terminus. These structural differences could result in differences in antimicrobial activity.

Differences in assay conditions in vitro could also contribute to differences in antimicrobial activity of $\alpha$ - and $\beta$-defensins. Human $\alpha$-defensins are most active against metabolically-active bacteria (3). For this reason, they are usually assayed in dilute culture medium. The activity of human $\beta$-defensins may not be influenced by the metabolic state of the bacteria. They are usually assayed in buffer without nutrients (e.g. refs. 17-21). The activity of defensins in vitro can also be influenced by the presence of salt, divalent cations and protein $(16,22)$.

\section{Defensins and Oral Health}

\section{$\alpha$-Defensins in Oral Tissues}

Neutrophil $\alpha$-defensins are thought to protect the junctional epithelium and teeth. $\alpha$-Defensins are found in junctional epithelium $(23,24)$. $\beta$-Defensins have not been detected in the junctional epithelium $(25,26)$.

\section{$\alpha$-Defensins in Saliva}

Neutrophil $\alpha$-defensins are stored in the active form at high levels in cytoplasmic secretory granules and are released into phagolysosomes or the extracellular phase during degranulation. Neutrophils enter crevicular fluid at the gingival sulcus. Neutrophils lyse as crevicular fluid flows into low ionic strength saliva. Goebel et al. (27) used LC/MS (liquid chromatography/mass spectrometry) to measure $\alpha$-defensins in clarified mixed saliva from normal healthy subjects and reported HNP-1 and HNP-2 concentrations of $8.6 \pm 8.0 \mu \mathrm{g} / \mathrm{mL}$ and $5.6 \pm 5.2 \mu \mathrm{g} / \mathrm{mL}$. These levels correspond to concentrations of $2.5 \pm 2.3$ and $1.7 \pm 1.5 \mu \mathrm{M}$. 
Mizukawa et al. (28) measured HNP-1 in saliva by HPLC (high pressure liquid chromatography) and reported levels of $0.8 \mu \mathrm{g} / \mathrm{mL}$ (about $0.2 \mu \mathrm{M}$ ) in normal subjects and levels about 10 -fold higher in saliva from patients with oral inflammation.

Pütsep et al. (29) measured levels of $\alpha$-defensins and LL-37 in neutrophils, blood plasma and saliva from normal controls and individuals with the genetic disorder morbus Kostmann, which results in severe congenital neutropenia. The neutropenia was corrected by treating patients with granulocyte-colony stimulating factor (GCSF), but the patients continued to have severe infections and periodontal disease. The neutrophils of GCSF-treated patients had a normal respiratory burst and normal levels of the granule protein lactoferrin, but the HNP-1 level was only $30 \%$ of that in controls, and the LL-37 level was only 1 to $2 \%$ of that in controls. This study indicates the importance of neutrophil antimicrobial peptides in controlling pathogenic bacteria including periodontal pathogens, but suggests that LL-37 plays a more important role in this disorder.

Tao et al. (30) measured antimicrobial peptides in clarified mixed saliva from 149 middle school children and looked for a correlation with caries experience of the children. ELISA or slot-blot immunological assays were used to assay HNP 1-3, HBD-3 and LL37. The median values for HNP 1-3, HBD-3 and LL-37 were $0.61,0.31$ and $3.07 \mu \mathrm{g} / \mathrm{mL}$, respectively. These values correspond to concentrations of about $0.18 \mu \mathrm{M}$ HNP 1-3, 0.06 $\mu \mathrm{M}$ HBD-3, and $0.74 \mu \mathrm{M}$ LL-37. The median level of HNP 1-3 in saliva from caries-free children $(0.89 \mu \mathrm{g} / \mathrm{mL})$ was significantly higher than that in saliva from children with caries $(0.5 \mu \mathrm{g} / \mathrm{mL})$. Levels of HBD-3 and LL-37 did not correlate with caries experience. Dale et al. (31) proposed that low levels of $\alpha$-defensins in saliva may lead to greater caries-susceptibility.

Fanali et al. (32) found that $\alpha$-defensins were significantly lower in saliva of edentulous patients than in that of age-matched controls with at least 25 teeth. It was proposed that $\alpha$-defensins are lower in saliva of edentulous patients due to the absence of creviculae where neutrophils enter the oral cavity and that low $\alpha$-defensin levels in edentulous patients could contribute to their increased risk of oral infection.

\section{$\alpha$-Defensins in GCF}

McKay et al. (33) recovered HNP 1-3 from gingival crevicular fluid (GCF) with antibody-coated beads and measured the $\alpha$-defensins using ELISA. HNP 1-3 were detected at all sites tested and ranged from 270 to $2000 \mathrm{ng} / \mathrm{site}$. The local $\alpha$-defensin concentration was estimated to be in the $\mathrm{mg} / \mathrm{mL}$ range.

Lundy et al. (34) used MALDI-TOF (matrix-assisted laser desorption and ionization-time of flight) MS to detect HNP 1-3 in GCF from 11 periodontitis patients and 12 healthy control subjects. The technique was not quantitative, but samples were scored based on the relative intensity of the characteristic triad of HNP 1-3 peaks in the 
samples. Of the samples from healthy subjects, $42 \%$ were given the maximum score for HNP 1-3, while only $18 \%$ of the samples from periodontitis patients were given the highest score.

Bostanci et al. (35) used ELISA to measure HNP 1-3 in GCF from 5 generalized aggressive periodontitis patients and 5 healthy subjects. The $\alpha$-defensins were not detected in samples from diseased subjects, but the level was $0.125 \pm 0.129 \mu \mathrm{g} / \mathrm{mL}$ in samples from healthy subjects.

Ngo et al. (36) analyzed GCF from inflamed sites of patients with a history of periodontal disease but in the maintenance phase of treatment. The $\alpha$-defensins HNP 1-3 were detected in all of the unfractionated GCF samples analyzed by MALDI-TOF MS.

Contrasting results were obtained by Puklo et al. (37). HNP 1-3 levels were measured by ELISA in GCF from severe periodontitis patients with no known congenital deficiency or dysfunction of neutrophils and compared with levels in healthy controls. $\alpha$ Defensin levels were 1.2, 17.6, and $73.9 \mu \mathrm{g} / \mathrm{mL}$ in GCF from normal controls, aggressive periodontitis, and chronic periodontitis, respectively. Concentrations were $0.3,5.1$, and $21.5 \mu \mathrm{M}$ based on an average molecular weight for the $\alpha$-defensins.

Measurements of $\alpha$-defensins varied in these studies with some authors reporting higher levels in GCF from periodontitis patients and others reporting higher levels in GCF from healthy subjects. These variations may result from differences in site selection, sampling techniques, and sample handling procedures. Proteolysis of the $\alpha-$ defensins by enzymes from neutrophils or periodontal pathogens may also influence the results.

\section{$\beta$-Defensins in Oral Tissues}

$\beta$-Defensins are expressed in gingiva, tongue, salivary glands and mucosa (38). In human gingival tissue, HBD-1 and HBD-2 were expressed in normal, non-inflamed tissue (23). The highest levels of expression were at the gingival margin near the site of plaque formation and within the sulcular epithelium during states of inflammation. In contrast, HBD-3 expression was observed primarily in the basal layer, as well as in Merkel and Langerhan cells, in healthy tissue. However, the expression pattern changed in persons with periodontitis, with HBD-3 expression extending to the superficial spinous layers (39). HBD-2 and HBD-3 mRNA levels were increased in biopsies from periodontitis tissue (40).

HBD-3 expression was upregulated in oral epithelial cells by interferon-gamma (10), various bacteria (9), and by A.a. (41). Significantly higher levels of HBD-3 expression were found in healthy tissues as compared with diseased tissues. High levels of HBD-3 mRNA in healthy tissues suggest a potentially important protective role for $\beta$ defensins in the host immune response to infection by periodontal pathogens. 


\section{$\beta$-Defensins in Saliva}

Mathews et al. (38) detected HBD-1 and HBD-2 in saliva with an immunological Western blot technique. As described above, Tao et al. (30) measured HBD-3 in unstimulated whole saliva from children. The median HBD-3 concentration was $0.31 \mu \mathrm{g} /$ $\mathrm{mL}(0.06 \mu \mathrm{M})$. The maximum HBD-3 level measured was $6.2 \mu \mathrm{g} / \mathrm{mL}$ or $1.2 \mu \mathrm{M}$. Local concentrations of $\beta$-defensins at the epithelial cell surface are probably much higher than those detected after dilution into saliva.

\section{$\beta$-Defensins in GCF}

Diamond et al. (42) used antibody-capture SELDI-TOF MS to detect HBD-1 and HBD-2 in GCF. The major secreted forms were 47 and 41 amino acid long, consistent with sequences shown in Figure 1.1. HBD-3 was not detected.

Brancatisano et al. (43) reported that HBD-3 was readily detected in GCF of healthy individuals by ELISA, but was drastically reduced in GCF from periodontitis patients. Genetic factors and destruction of HBD-3 by bacterial proteases were proposed as possible reasons for the inverse correlation of HBD-3 levels with severity of disease.

\section{Defensins and Periodontal Pathogens}

Periodontal pathogens are bacteria that are often found at sites of gingivitis and periodontitis and which have a role in the disease process (44-46). Many periodontal pathogens are gram-negative anaerobic bacteria including Aggregatibacter actinomycetemcomitans (A.a.), Porphyromonas gingivalis (P.g.), Prevotella intermedia (P.i.), Prevotella denticola (P.d.), and Fusobacterium nucleatum (F.n.).

All of these bacteria are resistant to the antimicrobial action of human $\alpha$-defensins in vitro (47-50). Resistance to $\alpha$-defensins of human neutrophils is probably important to the ability of these bacteria to survive and cause disease in a neutrophil-rich environment like inflamed oral tissues $(51,52)$.

These bacteria are not resistant to all cationic antimicrobial peptides. They are killed by the rabbit $\alpha$-defensin NP-1 (53) and by protegrins, small defensin-like cationic peptides isolated from pig neutrophils $(47,48)$.

These periodontal pathogens are also killed by human $\beta$-defensins in vitro $(6,17,19-21,54)$. HBD-3 is the most active $\beta$-defensin. $\beta$-Defensins are probably important in protecting epithelial cells and the underlying oral tissues of healthy individuals against gram-negative periodontal pathogens. 
Ouhara et al. (20) studied the periodontal pathogens A.a., P.g., P.i. and F.n. and found all were susceptible to the bactericidal activity of $\beta$-defensins, but there was variability in the degree of activity against the different bacteria and different strains. All F.n. strains showed the highest sensitivity to HBD-3 compared with those of other bacteria.

The resistance of periodontal pathogens to human leukocyte $\alpha$-defensins and the ability of human epithelial cell $\beta$-defensins to kill these bacteria is probably a result of differences in structure of the two classes of peptides. Differences in defensin structure could have effects on the ability of defensins to bind to bacteria or to insert into bacterial membranes.

\section{HBD-3 Structure and Antimicrobial Activity}

Miyasaki et al. (53) showed that the rabbit defensin NP-1 killed A.a. NP-1 has two hydrophobic valine residues at the $\mathrm{N}$-terminus before the first cysteine and two cationic arginine residues at the $\mathrm{C}$-terminus after the last cysteine. In contrast, the HNP-2 sequence begins and ends with cysteine and has no additional residues (Figure 1.1). Raj et al. (49) synthesized analogs of HNP-2 with additional hydrophobic or cationic residues at the $\mathrm{N}$ - or $\mathrm{C}$-terminus. The most effective analog had two arginine residues added at both the N-terminus and C-terminus. This peptide RR-HNP2-RR was more effective than HNP-1 against Streptococcus mutans (S. mutans) and Candida albicans $(C$. albicans) as well as the periodontal pathogens A.a. and P.g. The analog with valine at the $\mathrm{N}$-terminus and arginine at the C-terminus, VV-HNP2-RR, also killed A.a. but was much less active, with an LD90 of $25 \mu \mathrm{M}$ vs. $1 \mu \mathrm{M}$ for RR-HNP2-RR. This observation suggests that the additional residues at the $\mathrm{N}$ - and $\mathrm{C}$-terminus of $\beta$-defensins account for their greater activity than $\alpha$-defensins against periodontal pathogens. The results also suggest that increasing the net charge of the defensin is more important than adding hydrophobic residues (55).

Wu et al. (56) synthesized HBD-3 analogs with all possible disulfide pairings and also a linear form with the cysteine residues replaced by $\alpha$-amino isobutyric acid. Tests of the antimicrobial activity of these analogs against Escherichia coli (E. coli) ATCC 25922 showed that the disulfide bonds of HBD-3 were not required for antimicrobial activity. All the analogs had similar activities against $E$. coli, indicating that cysteine residues or a particular arrangement of disulfide bonds was not required for antibacterial activity. Studies with intestinal mouse $\alpha$-defensins known as cryptdins suggested that a major function of the highly conserved disulfide bonds is to protect defensins from proteases $(57,58)$.

Klüver et al. (59) studied the influence of disulfide bonds and cysteine substitution on antimicrobial activity. They concluded that positively-charged peptides with high hydrophobicity such as native HBD-3 exhibit high antimicrobial activity. They reported that an HBD-3 analog missing the first $5 \mathrm{~N}$-terminal amino acids retained full 
antimicrobial activity against $E$. coli DSM 1103 . Analogs of the N-terminally truncated HBD-3 with different disulfide pairings or no disulfide bonds also had strong antimicrobial activity. These results suggest that disulfide bonds and the hydrophobic Nterminus of HBD-3 were not important for activity against $E$. coli, but activity against periodontal pathogens was not tested.

Peptides were synthesized that correspond to the N-terminal and C-terminal regions of HBD-3, and their antimicrobial activity was tested against a wide variety of micro-organisms (60). However, activity of these peptides against periodontal pathogens was not tested. Figure 1.3 compares sequences of the peptides with the sequence of HBD-3.

The synthetic peptide known as CHRG07 corresponds to the seventeen Nterminal residues of HBD-3 but with serine (S) replacing the one cysteine $(\mathrm{C})$ residue to prevent disulfide bond formation. It contains the 4 hydrophobic and 4 cationic amino acid residues of the $\mathrm{N}$-terminal sequence of HBD-3. It has a net charge of +4 and a molecular weight of 1981 .

The CHRG07 peptide resembles HBD-3 in that it has a hydrophobic N-terminus and a cationic $\mathrm{C}$-terminus. However, $\mathrm{CHRG07}$ was much less active than HBD-3 against E. coli (60). The CHRG07 peptide did have measurable activity against both gramnegative and gram-positive bacteria and the fungus $C$. albicans. It had strong activity against certain pathogenic bacteria.

The synthetic peptide known as CHRG01 corresponds to the fourteen C-terminal residues of HBD-3 but with serine $(\mathrm{S})$ replacing the three cysteine $(\mathrm{C})$ residues. The CHRG01 peptide contains no hydrophobic amino acid residues, but has eight cationic residues. It has a net charge of +8 and a molecular weight of 1662 .

The N-terminal residues of CHRG01 are lysine $(\mathrm{K})$ and serine $(\mathrm{S})$. The peptide does not contain the GKC sequence found in HBD-3. A GXC sequence is found near the $\mathrm{C}$ terminus in all mammalian defensins. Evidence has been presented that the glycine $(\mathrm{G})$ residue and the GXC sequence are important to correct folding, disulfide bond formation, and antimicrobial activity (61). Therefore, CHRG01 does not have a feature that was reported to be important to defensin activity. Nevertheless, CHRG01 was about twice as active as HBD-3 against E. coli on a molar basis and about six times as active on a weight basis. CHRG01 was also active against gram-negative Pseudomonas aeruginosa but had little or no activity against gram-positive bacteria or C. albicans.

\section{LPS and Gram-negative Periodontal Pathogens}

Gram-negative bacteria have an outer membrane and an inner membrane. Lipopolysaccharide (LPS) makes up the outer layer of the outer membrane of gramnegative bacteria $(62,63)$. Each bacterial cell is covered by about 2 million LPS 
HBD-3

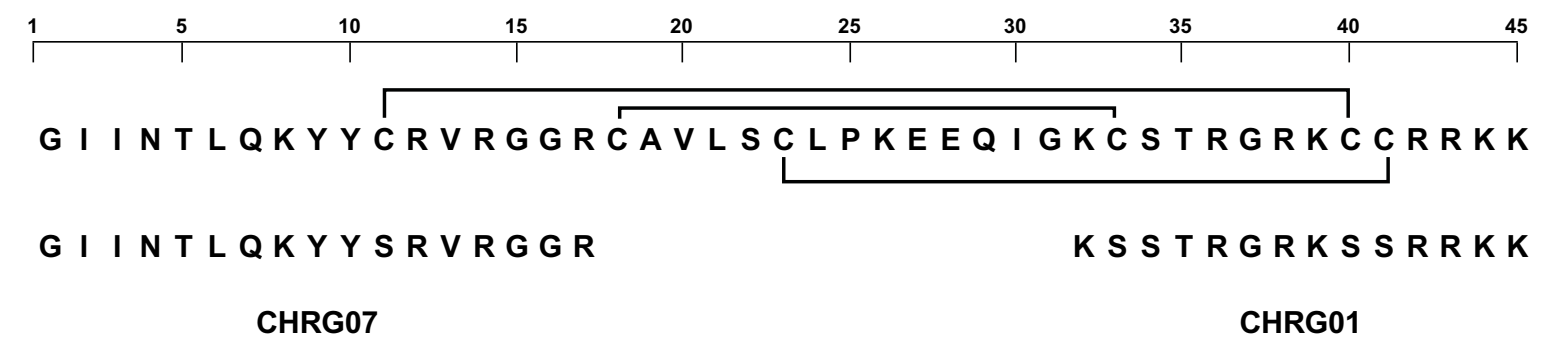

Figure 1.3 Sequences of HBD-3 and peptides CHRG07 and CHRG01 
molecules. LPS participates in physiological membrane functions and is essential for bacterial growth and viability (64). LPS represents a primary target for interactions with antibacterial drugs and components of the host immune system (65).

Each LPS molecule (Figure 1.4) has 3 segments consisting of oligosaccharide, core, and lipid A. The oligosaccharide (O-antigen) segment is made up of a long carbohydrate polymer with a repeating pattern of 6-carbon sugars (hexoses) and is attached to a glucose residue of the core segment. O-antigen structures are highly variable, compared with those of the core and lipid A, possibly helping bacteria evade the immune system (64).

The core consists of a short carbohydrate polymer with hexoses and unusual 7and 8-carbon sugars. Phosphate groups, which add negative charges, and ethanolamine groups, which add positive charges, are often attached to the core region. The core segment is covalently bound to the lipid A segment.

Lipid A, the hydrophobic anchor of LPS, is a glucosamine-based phospholipid that makes up the outer monolayer of the outer membrane of most gram-negative bacteria. The characteristic structural features of lipid A are two amino-sugars with phosphate groups. The phosphate groups are needed to trigger the endotoxin response in human cells $(64,66)$. Usually six fatty acids containing long hydrocarbon chains, which are oily and hydrophobic, are attached to the amino sugars. The lipid A segment holds the LPS molecule in the outer membrane of the gram-negative organism. LPS and lipid A are potent activators of macrophages, resulting in the rapid induction of the synthesis of tumor necrosis factor (67), interleukin 1 (66), and other proteins.

Figure 1.4 also shows structures that can be obtained by chemical treatment of LPS and which were used in this study. Alkaline hydrolysis of LPS removes the fatty acids leaving deacylated-LPS (deacyl-LPS), which is also known as detoxified LPS because the endotoxin activity is lost. Acid hydrolysis of LPS removes the oligosaccharide and core segments, leaving the lipid A segment. Purified lipid A has the full endotoxin activity of LPS $(64,68)$. 
LPS

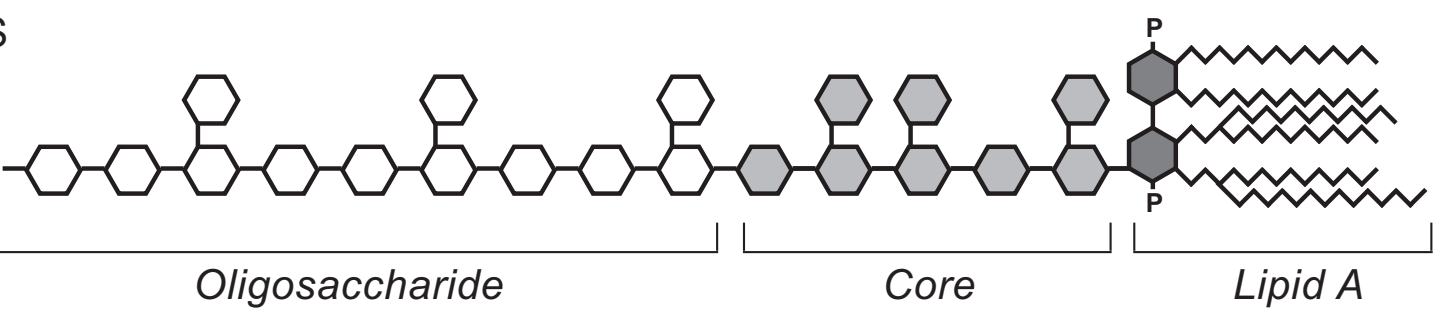

Deacyl-LPS

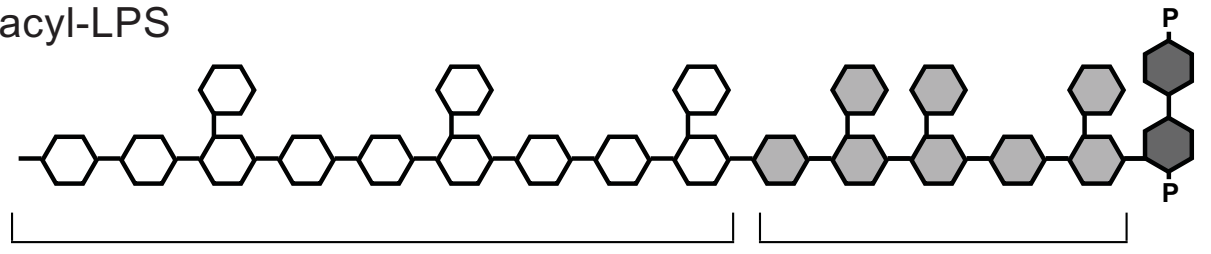

Lipid A

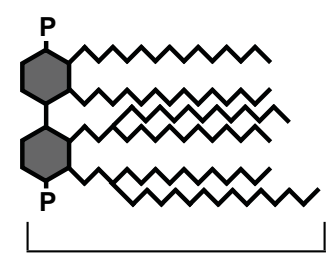

Figure 1.4. Representations of LPS, deacyl-LPS, and lipid A structures Sugars are represented by hexagons, phosphate groups by $\mathrm{P}$, and fatty acids by pleated lines. 


\section{CHAPTER 2. SPECIFIC OBJECTIVES}

The overall objective of this study was to study differences in the properties of human $\alpha$ - and $\beta$-defensins that might account for the resistance of periodontal pathogens to $\alpha$-defensins and their susceptibility to $\beta$-defensins.

The first objective was to determine whether the $\beta$-defensin HBD-3 is more effective than the $\alpha$-defensin HNP-1 against the periodontal pathogen $A$.a. and nonpathogenic gram-negative $E$. coli bacteria when tested under the usual conditions for $\beta$ defensins (in buffer solution) and the usual assay conditions for $\alpha$-defensins (in buffer with dilute culture medium to permit bacterial metabolism and growth). The aim of these experiments was to determine whether A. $a$. is killed by HBD-3 but resistant to HNP-1 under all conditions or whether differences in assay conditions account for the differences in results reported in previous studies.

The second objective was to determine whether the additional amino acid residues at the N-terminus and C-terminus of HBD-3 can account for HBD-3 activity against $A$.a. The synthetic peptides CHRG07 and CHRG01 were incubated with A.a. and E. coli to determine whether killing of A.a. and control bacteria was accounted for by the mixture of hydrophobic and cationic residues at the N-terminus of HBD-3 or the cationic residues at the C-terminus.

The third objective was to determine whether HBD-3 binds to purified LPS and whether there is any difference in HBD-3 binding to LPS from A.a. or E. coli. Binding was evaluated by the ability of purified LPS to absorb HBD-3 and block killing of A.a. or E. coli. Binding to purified LPS could indicate that LPS is the receptor for HBD-3 on the outer membranes of $A . a$. and other gram-negative bacteria.

The fourth objective was to determine whether the hydrophobic fatty acids of the lipid A portion of LPS is the site where HBD-3 binds to LPS. The ability of purified lipid A and deacyl-LPS to absorb HBD-3 and block killing of bacteria was evaluated. If lipid A blocked but deacyl-LPS did not, the results would indicate that HBD-3 binds to the fatty acids of lipid A. Binding of the hydrophobic N-terminus of HBD-3 to the hydrophobic portion of LPS might account for the activity of HBD-3 against A.a. 


\title{
CHAPTER 3. MATERIALS AND METHODS
}

\author{
Materials
}

\section{Chemicals}

Bovine serum albumin was from Sigma Aldrich Chemical Co., St. Louis, MO. Sodium bicarbonate, triethylamine, and hydrochloric acid were from Fisher Scientific, Pittsburgh, PA. Bacto-agar and Trypticase Soy Broth (TSB) were from Becton Dickinson, Sparks, MD.

\section{Antimicrobial Peptides}

HNP-1 was purified from a 10\% acetic acid extract of human neutrophil granules by the method of Ganz et al. (3) in the laboratory of Dr. Thomas at the UTHSC College of Dentistry. The protein concentration of purified HNP-1 was determined by the method of Lowry et al. (69) with bovine serum albumin as the standard.

Four $1 \mathrm{mg}$ vials of sterile recombinant HBD-3 were purchased from ProSpecTany TechnoGene Ltd., Rehovot, Israel. HBD-3 was provided as a lyophilized powder without additives and was stored dry at $-80^{\circ} \mathrm{C}$ until needed. HBD-3 $(1.0 \mathrm{mg})$ was dissolved in $0.647 \mathrm{~mL} 0.01 \%$ acetic acid to give a $300 \mu \mathrm{M}$ solution, assuming a molecular weight of 5155. The $300 \mu \mathrm{M}$ HBD-3 solution was aliquoted and stored at $-80^{\circ} \mathrm{C}$. Solutions of $100,50,30$, and $10 \mu \mathrm{M}$ HBD-3 were prepared by dilution of the 300 $\mu \mathrm{M}$ solution in $0.01 \%$ acetic acid and stored at $-80^{\circ} \mathrm{C}$.

CHRG07 and CHRG01 were synthesized by American Peptide Co, Inc., Sunnyvale, CA. Peptides were provided as lyophilized dry powders with trifluoroacetate as a counter ion.

A certificate of analysis was provided for each peptide. Purity was $95.6 \%$ and 98.6\% for CHRG07 and CHRG01, respectively. Purity was calculated from the areas of major and minor peaks on an HPLC chromatogram. The amino acid composition was determined for each peptide and was within expected error limits of the composition of the requested sequence. Molecular weights of 1982 and 1662 were determined for CHRG07 and CHRG01 by electrospray liquid chromatography mass spectrometry (LC/ MS) and were close to or the same as the calculated values of 1981 and 1662.

One vial containing $5 \mathrm{mg}$ net peptide weight was provided for each peptide. The peptides were stored dry at $-80^{\circ} \mathrm{C}$ until they were solubilized. Molecular weights of 1981 and 1662 were calculated for CHRG07 and CHRG01, respectively. CHRG07 (5.0 mg) was dissolved in $2.523 \mathrm{~mL} 0.01 \%$ acetic acid to give a $1000 \mu \mathrm{M}$ solution, assuming a 
molecular weight of 1981. Solutions of 300, 100, 50, 30, and $10 \mu \mathrm{M}$ CHRG07 were prepared by dilution of the $1000 \mu \mathrm{M}$ CHRG07 solution in $0.01 \%$ acetic acid. CHRG01 $(5.0 \mathrm{mg}$ ) was dissolved in $3.008 \mathrm{~mL} 0.01 \%$ acetic acid to give a $1000 \mu \mathrm{M}$ solution, assuming a molecular weight of 1662 . Solutions of $300,100,50,30$, and $10 \mu \mathrm{M}$ CHRG01 were prepared by dilution of the $1000 \mu \mathrm{M}$ CHRG01 solution in $0.01 \%$ acetic acid. The peptide solutions were aliquoted and stored at $-80^{\circ} \mathrm{C}$.

\section{LPS, Deacyl-LPS, and Lipid A}

LPS from E. coli of serotype O111:B4 was purchased from List Biological Laboratories, Campbell, CA. A.a. LPS was purified from the Y4 strain in the laboratory of Dr. Jegdish Babu at the UTHSC College of Dentistry using the method of Millar et al. (70) in which LPS is extracted from an outer membrane fraction (71) by the hot waterphenol method of Westphal and Jann (72).

Deacylated (detoxified) LPS (deacyl-LPS), prepared by alkaline hydrolysis (73) of LPS from E. coli serotype O111:B4, was purchased from Sigma Aldrich Chemical Co. Lipid A (diphosphoryl) prepared by acid hydrolysis (74) from LPS of the rough (Re) mutant E. coli K12-D31m4 was purchased from List Biological Laboratories Inc.

LPS and deacyl-LPS were dispersed in water or $10 \mathrm{mM}$ potassium phosphate $\mathrm{pH}$ 7.4 buffer by incubating $5 \mathrm{~min}$ in a sonicator bath at $25^{\circ} \mathrm{C}$. Lipid A was solubilized with triethylamine by the procedure of Tanamoto et al. (75).

\section{Bacteria}

All bacterial strains were obtained from the American Type Culture Collection (ATCC), Manassas, VA. E. coli ML-35 (ATCC 43827) was used as the standard test organism for measuring defensin activity. The Y4 strain of A.a. (ATCC 43718) is serotype $b$.

\section{Methods}

\section{Bacterial Inocula}

E. coli ML-35 bacteria were grown to early stationary phase in Medium AGlucose $(0.06 \mathrm{M}$ potassium phosphate, $1.7 \mathrm{mM}$ sodium citrate, $7.6 \mathrm{mM}$ ammonium sulfate, $0.014 \mathrm{mM}$ magnesium sulfate, $20 \mathrm{mM}$ glucose) (76). A.a. bacteria were grown as indicated below in filter-sterilized Trypticase soy broth (TSB). Portions $(1.5 \mathrm{~mL})$ of the bacterial cultures were frozen at $-80^{\circ} \mathrm{C}$. The frozen cultures were used to inoculate cultures for experiments. 


\section{Bacterial Cultures}

An inoculum was thawed and a $1 \mathrm{~mL}$ portion was added to $100 \mathrm{~mL}$ of TSB. $E$. coli ML-35 bacteria were grown for $16 \mathrm{~h}$ to stationary phase in foam-stoppered flasks at $37^{\circ} \mathrm{C}$ with continuous mixing in a rotary shaker for aeration. A.a. Y4 was grown for $24 \mathrm{~h}$ to stationary phase at $37^{\circ} \mathrm{C}$ with continuous mixing in sealed $100 \mathrm{~mL}$ bottles to restrict aeration. Media for both liquid and solid cultures of $A$.a. were sterilized by ultrafiltration through 0.2 micron nitrocellulose filters (Nalgene Co., Rochester, NY). Media for liquid cultures of $E$. coli were sterilized by ultrafiltration, and media for solid-phase cultures of E. coli were sterilized by autoclaving.

For experiments with $E$. coli, the bacteria in a $10 \mathrm{~mL}$ portion of a stationary phase culture were collected and washed twice by centrifugation at $17,000 \mathrm{xg}$ for $12 \mathrm{~min}$ at $4^{\circ} \mathrm{C}$ with $10 \mathrm{mM}$ potassium phosphate $\mathrm{pH} 7.4$ buffer. The washed bacteria were suspended in the buffer solution to an optical density of 0.6 at $600 \mathrm{~nm}$ to give $2 \times 10^{8}$ colony forming units $(\mathrm{CFU}) / \mathrm{mL}$.

For experiments with A.a., a portion of a $24 \mathrm{~h}$ culture was diluted 10 fold to $1 \mathrm{x}$ $10^{8} \mathrm{CFU} / \mathrm{mL}$ with $10 \mathrm{mM}$ phosphate buffer at $25^{\circ} \mathrm{C}$ and used immediately.

\section{Antibacterial Assay}

Bacteria $\left(10^{6} \mathrm{CFU} / \mathrm{mL}\right)$ in $100 \mu \mathrm{L}$ total volume $(E$. coli) or $200 \mu \mathrm{L}$ total volume (A.a.) were incubated with gentle mixing in $10 \mathrm{mM}$ potassium phosphate $\mathrm{pH} 7.4$ buffer with or without $1 \%$ TSB. Antimicrobial peptides and LPS were added in various concentrations as indicated for each experiment. Incubation mixtures with $E$. coli were incubated 2 or $4 \mathrm{~h}$ at $37^{\circ} \mathrm{C}$ aerobically in $1.8 \mathrm{~mL}$ polypropylene vials. Incubation mixtures with $A$.a. were incubated 2 or $4 \mathrm{~h}$ at $37^{\circ} \mathrm{C}$ in 96 -well plates that were placed inside Anaerogen ${ }^{\mathrm{TM}}$ GasPak Pouch ${ }^{\mathrm{TM}}$ Anaerobic System (Oxoid Ltd., Basingstoke, Hampshire, England) to lower the oxygen $\left(\mathrm{O}_{2}\right)$ concentration and raise the carbon dioxide $\left(\mathrm{CO}_{2}\right)$ concentration. At the end of the incubation, the number of viable bacteria was determined by making serial 1:10 dilutions in sterile $10 \mathrm{mM}$ phosphate $\mathrm{pH} 7.4$ buffer, plating $0.8 \mathrm{~mL}$ portions of the dilutions on solid growth medium (TSB/2\% agar), and counting bacterial colonies after 1 to 2 days at $37^{\circ} \mathrm{C}$. E. coli bacteria on solid media were incubated under air at $37^{\circ} \mathrm{C}$. A. a. bacteria on solid media were incubated under $95 \%$ air/ $5 \% \mathrm{CO}_{2}$ at $37^{\circ} \mathrm{C}$. The number of viable bacteria $/ \mathrm{mL}$ in the incubation mixture was calculated.

\section{Estimated Molecular Weights of LPS, Deacyl-LPS, and Lipid A}

Molecular weights were estimated or calculated for LPS, deacyl-LPS, and lipid A so that the number of molecules needed to block killing by HBD-3 could be determined. All LPS preparations are heterogeneous due to variation in the number of repeating units 
in the oligosaccharide part and varying amounts of substitution in the core. An average molecular weight of 10,000 Da was reported (77) for LPS of E. coli serotype O111:B4 and was used in calculations in this study. Because no estimates for the molecular weight of LPS from the A.a. Y4 strain were found, the same value of 10,000 Da was used.

Figure 1.4 shows schematic representations of the structure of LPS, deacyl-LPS, and lipid A. Based on the structure, a molecular weight of 8,704 was calculated for deacyl-LPS. The calculation is based on subtracting the molecular weights of one $12-$ carbon fatty acid, one 14-carbon fatty acid, and four 14-carbon beta-hydroxy fatty acids from 10,000, and adding the molecular weight of six water molecules. A molecular weight of 1,797 was calculated for lipid A.

\section{Data Analysis}

All experiments were performed at least twice with duplicate samples. The mean \pm S.E. (Standard Error), the number of values averaged (n), and the p (probability) value were determined. Statistical significance was evaluated by Analysis of Variance (ANOVA) followed by Scheffe's f test to calculate p values using StatView 5.0 software. Values less than 0.05 were considered significant. 


\section{CHAPTER 4. RESULTS}

\section{Activity of HNP-1 and HBD-3 under Differing Assay Conditions}

Our first objective was to compare the activity of $\alpha$-defensin HNP-1 and $\beta$ defensin HBD-3 in vitro against the periodontal pathogen $A$.a. and the control bacteria $E$. coli. We wanted to know whether HBD-3 is really more active than HNP-1 against $A$.a. or whether the reported differences in results were due to differences in assay conditions. In previous studies, $\alpha$ - and $\beta$-defensins were assayed under different conditions, which could result in differences in activity.

To assay antibacterial activity, bacteria at $10^{6} \mathrm{CFU} / \mathrm{ml}$ were incubated at $37^{\circ} \mathrm{C}$ with increasing concentrations of HNP-1 or HBD-3. These incubations were carried out in dilute culture medium (1\% TSB) with low ionic strength buffer $(10 \mathrm{mM}$ phosphate, $\mathrm{pH}$ 7.4) or in the low ionic strength buffer without nutrients. The dilute culture medium gave the bacteria all the nutrients needed for energy metabolism and growth. These are the usual assay conditions for $\alpha$-defensins. In contrast, $\beta$-defensins are usually assayed in low ionic strength buffer without nutrients.

Incubations with $A$.a. were carried out in multi-well plates, each placed inside an Anaerogen ${ }^{\mathrm{TM}}$ GasPak Pouch ${ }^{\mathrm{TM}}$ to lower the $\mathrm{O}_{2}$ concentration and raise the $\mathrm{CO}_{2}$ levels. These are better conditions for A.a. growth. E. coli were incubated in air. After incubation with HNP-1 or HBD-3, the number of live bacteria was determined by diluting, plating, and counting colonies.

Figure 4.1 shows results of the $\alpha$-defensin HNP-1 activity assay with the target organism $E$. coli in dilute culture medium. The bacteria started at a concentration of $10^{6}$ $\mathrm{CFU} / \mathrm{ml}$ and increased nearly 100 -fold to about $10^{8} \mathrm{CFU} / \mathrm{ml}$ during the $4 \mathrm{~h}$ incubation period. When HNP-1 was present during the incubation, there was little effect up to the 1 $\mu \mathrm{M}$ HNP-1 concentration, but with increasing concentrations an effect was seen at $3 \mu \mathrm{M}$ and higher. HNP-1 at 3 to $10 \mu \mathrm{M}$ killed $99 \%$ of the bacteria.

Figure 4.2 shows similar results were obtained with the $\beta$-defensin HBD-3 against the target organism E. coli under the same assay conditions. Concentrations of 5 to 10 $\mu \mathrm{M}$ HBD-3 gave 90 to $99 \%$ killing of E. coli.

Compared with the rapid growth of E. coli, A.a. grew slowly under these assay conditions, as shown in Figure 4.3. HNP-1 did not kill A.a. at concentrations up to 30 $\mu \mathrm{M}$. Therefore, A.a. was resistant to HNP-1 under these conditions. On the other hand, HBD- 3 caused significant killing of $A$.a. starting at the $3 \mu \mathrm{M}$ concentration, as shown in Figure 4.4. HBD-3 was even more effective against $A$.a. (Figure 4.4) than against $E$. coli (Figure 4.2). 


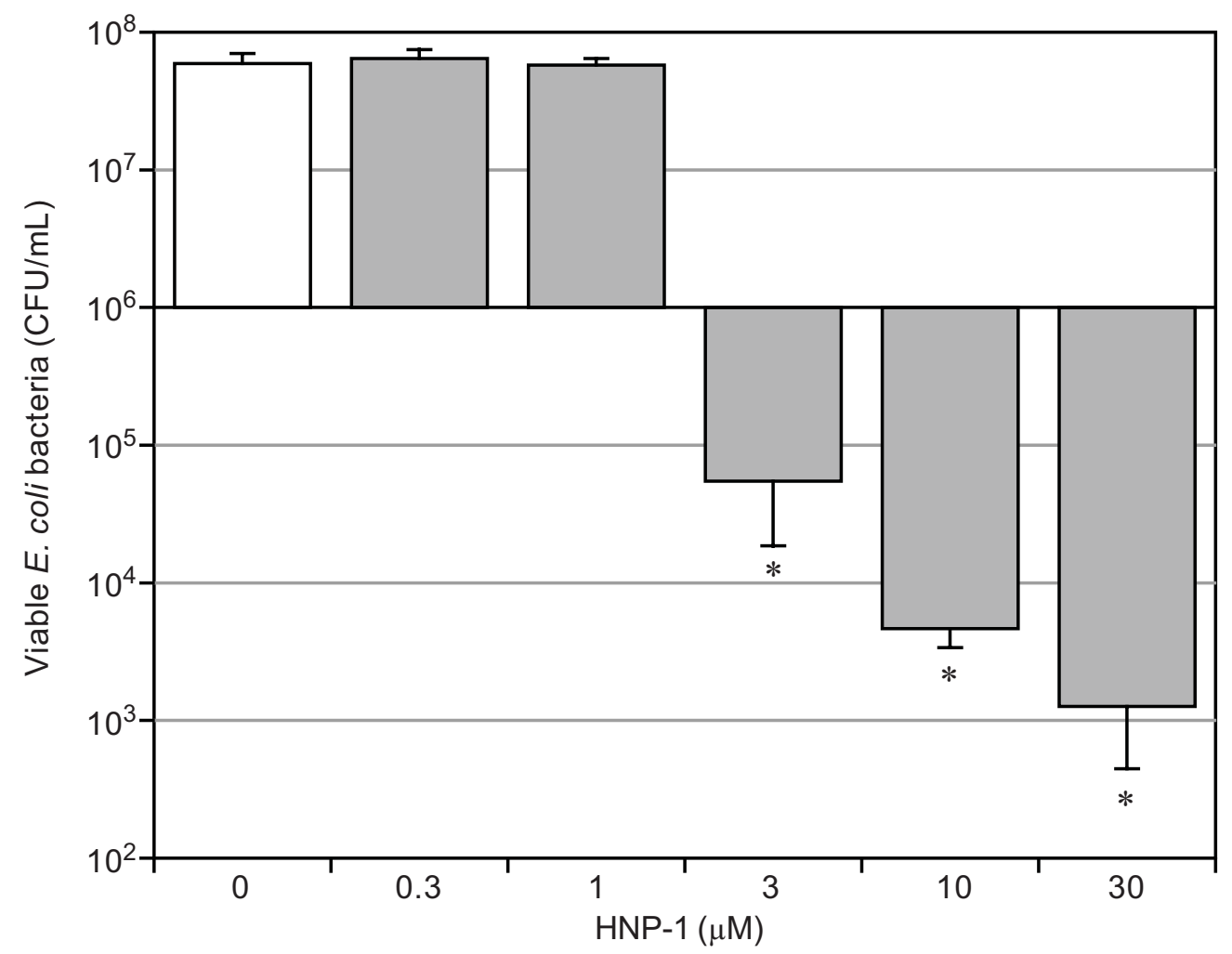

\begin{tabular}{lcccc} 
Conditions & $\begin{array}{c}\text { Viable bacteria } \\
\left(10^{6} \mathrm{CFU} / \mathrm{ml}\right)\end{array}$ & S.E. & $\mathrm{n}$ & P value \\
\hline Control $\left(4 \mathrm{~h}, 37^{\circ} \mathrm{C}\right)$ & 58.993 & 9.934 & 10 & - \\
HNP-1, $0.3 \mu \mathrm{M}$ & 63.646 & 10.403 & 4 & 1.0 \\
$\mathrm{HNP}-1,1.0 \mu \mathrm{M}$ & 57.260 & 6.662 & 4 & 1.0 \\
$\mathrm{HNP}-1,3.0 \mu \mathrm{M}$ & 0.055 & 0.036 & 4 & $0.003^{*}$ \\
$\mathrm{HNP}-1,10.0 \mu \mathrm{M}$ & 0.005 & 0.001 & 5 & $0.001^{*}$ \\
$\mathrm{HNP}-1,30.0 \mu \mathrm{M}$ & 0.001 & 0.001 & 4 & $0.003^{*}$ \\
\hline
\end{tabular}

Figure 4.1. HNP-1 kills $E$. coli in dilute culture medium

E. coli bacteria $\left(10^{6} / \mathrm{ml}\right)$ were incubated $4 \mathrm{~h}$ at $37^{\circ} \mathrm{C}$ in dilute culture medium without HNP-1 (control; white bar) or with 0.3 to $30 \mu \mathrm{M} \mathrm{HNP}-1$ (gray bars). Values shown on the logarithmic scale in the bar graph are shown in linear form in the table below the graph.

* Significantly different from the control value without HNP-1. 


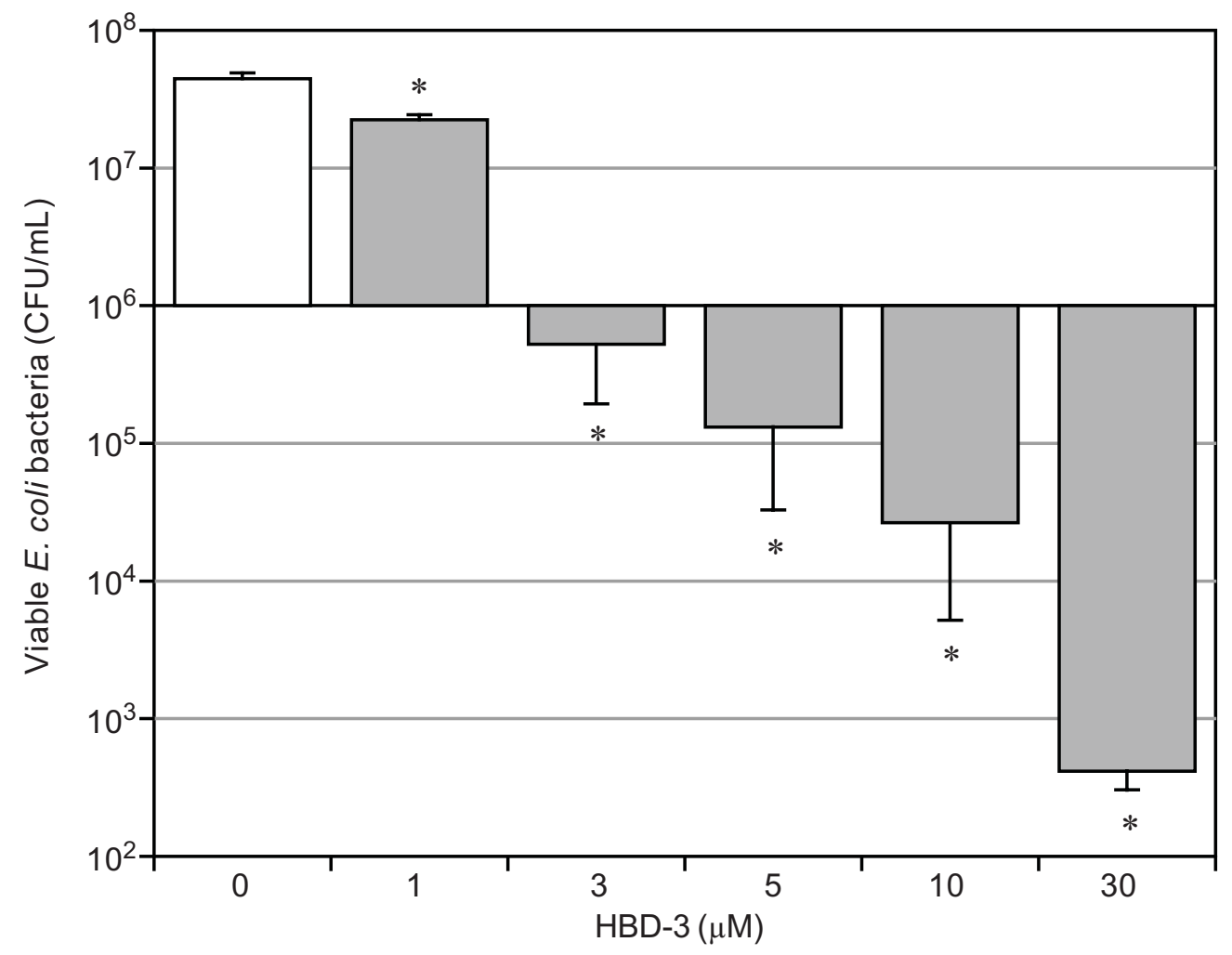

\begin{tabular}{lcccr} 
Conditions & $\begin{array}{c}\text { Viable bacteria } \\
\left(10^{6} \mathrm{CFU} / \mathrm{ml}\right)\end{array}$ & S.E. & $\mathrm{n}$ & P value \\
\hline Control $\left(4 \mathrm{~h}, 37^{\circ} \mathrm{C}\right)$ & 43.804 & 4.457 & 6 & - \\
HBD-3, $1 \mu \mathrm{M}$ & 22.219 & 1.832 & 6 & $<0.0001^{*}$ \\
HBD-3, $3 \mu \mathrm{M}$ & 0.522 & 0.330 & 6 & $<0.0001^{*}$ \\
HBD-3, $5 \mu \mathrm{M}$ & 0.129 & 0.097 & 6 & $<0.0001^{*}$ \\
HBD-3, $10 \mu \mathrm{M}$ & 0.026 & 0.021 & 6 & $<0.0001^{*}$ \\
HBD-3, $30 \mu \mathrm{M}$ & 0.000 & 0.000 & 5 & $<0.0001^{*}$ \\
\hline
\end{tabular}

Figure 4.2. HBD-3 kills $E$. coli in dilute culture medium

E. coli bacteria $\left(10^{6} / \mathrm{ml}\right)$ were incubated $4 \mathrm{~h}$ at $37^{\circ} \mathrm{C}$ in dilute culture medium without HBD-3 (control; white bar) or with 1 to $30 \mu \mathrm{M} \mathrm{HBD-3}$ (gray bars).

* Significantly different from the control value without HBD-3. 


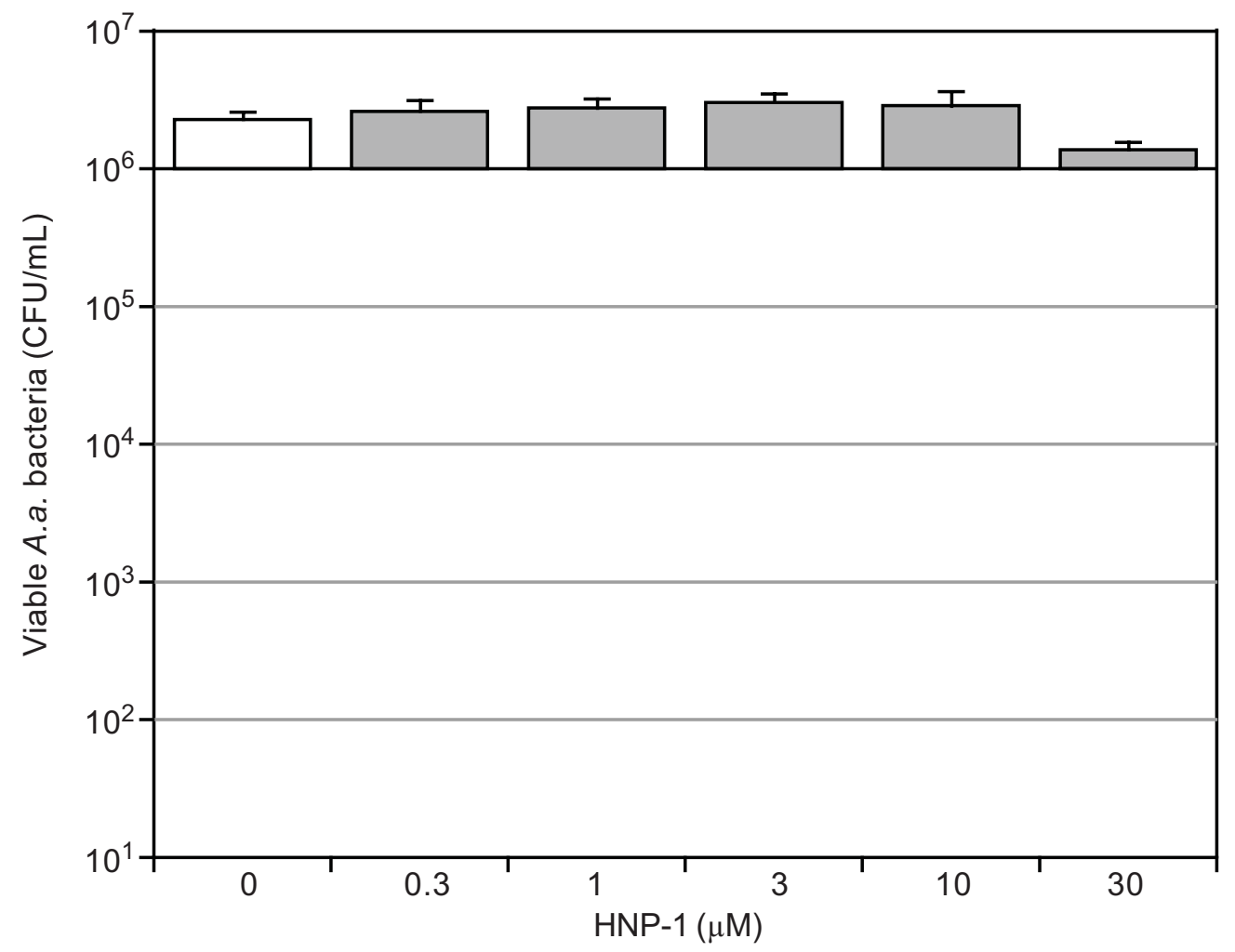

\begin{tabular}{lcccr} 
Conditions & $\begin{array}{c}\text { Viable bacteria } \\
\left(10^{6} \mathrm{CFU} / \mathrm{ml}\right)\end{array}$ & S.E. & $\mathrm{n}$ & P value \\
\hline Control $\left(4 \mathrm{~h}, 37^{\circ} \mathrm{C}\right)$ & 2.238 & 0.281 & 8 & - \\
HNP-1, $0.3 \mu \mathrm{M}$ & 2.575 & 0.502 & 4 & 1.0 \\
HNP-1, $1.0 \mu \mathrm{M}$ & 2.734 & 0.446 & 4 & 1.0 \\
HNP-1, $3.0 \mu \mathrm{M}$ & 2.988 & 0.425 & 4 & 0.9 \\
HNP-1, $10 \mu \mathrm{M}$ & 2.283 & 0.717 & 4 & 1.0 \\
HNP-1, $30 \mu \mathrm{M}$ & 1.356 & 0.177 & 6 & 0.7 \\
\hline
\end{tabular}

Figure 4.3. HNP-1 does not kill $\boldsymbol{A}$. $a$. in dilute culture medium

A.a. bacteria $\left(10^{6} / \mathrm{ml}\right)$ were incubated $4 \mathrm{~h}$ at $37^{\circ} \mathrm{C}$ in dilute culture medium without HNP-1 (control; white bar) or with 0.3 to $30 \mu \mathrm{M} \mathrm{HNP}-1$ (gray bars). 


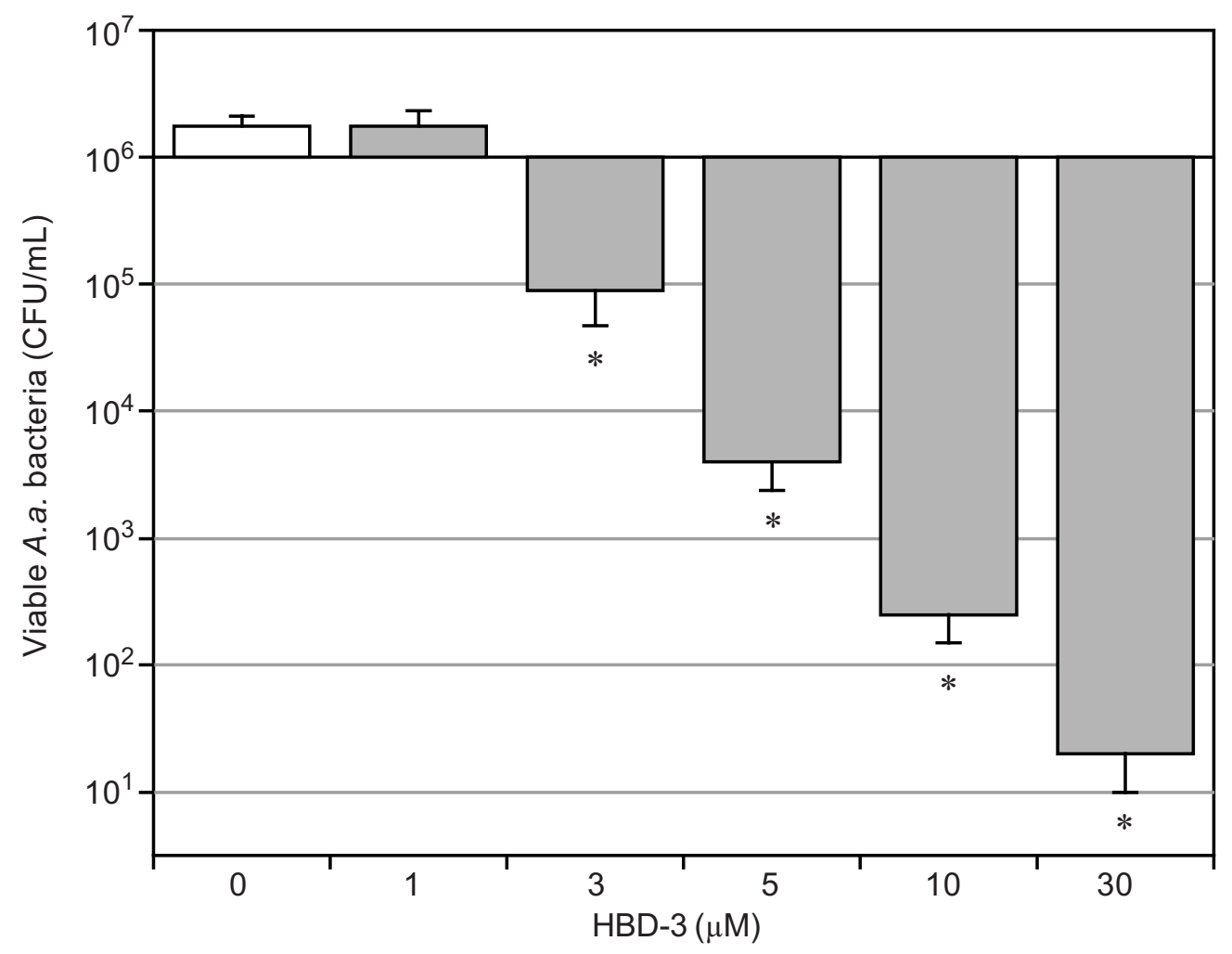

\begin{tabular}{lcccc} 
Conditions & $\begin{array}{c}\text { Viable bacteria } \\
\left(10^{6} \mathrm{CFU} / \mathrm{ml}\right)\end{array}$ & S.E. & $\mathrm{n}$ & P Value \\
\hline Control $\left(4 \mathrm{~h}, 37^{\circ} \mathrm{C}\right)$ & 1.769 & 0.329 & 4 & - \\
HBD-3, $1 \mu \mathrm{M}$ & 1.773 & 0.549 & 4 & 1.0 \\
HBD-3, $3 \mu \mathrm{M}$ & 0.088 & 0.041 & 4 & $0.02^{*}$ \\
HBD-3, $5 \mu \mathrm{M}$ & 0.004 & 0.002 & 4 & $0.01^{*}$ \\
HBD-3, $10 \mu \mathrm{M}$ & 0.000 & 0.000 & 4 & $0.01^{*}$ \\
HBD-3, $30 \mu \mathrm{M}$ & 0.000 & 0.000 & 4 & $0.02^{*}$ \\
\hline
\end{tabular}

Figure 4.4. HBD-3 kills $A . a$. in dilute culture medium

A.a. bacteria $\left(10^{6} / \mathrm{ml}\right)$ were incubated $4 \mathrm{~h}$ at $37^{\circ} \mathrm{C}$ in dilute culture medium without HBD-3 (control; white bar) or with 1 to $30 \mu \mathrm{M} \mathrm{HBD}-3$ (gray bars).

* Significantly different from the control value without HBD-3. 
The results show A.a. was resistant to HNP-1 but killed by HBD-3 when assayed under the usual conditions for measuring $\alpha$-defensin activity. HNP-1 had little or no effect on A.a. under these conditions. However, the $\beta$-defensin HBD-3 was active against both E. coli and A.a. in dilute culture medium.

Figures 4.5 through 4.8 show results obtained with assays in buffer rather than in dilute culture medium. Figure 4.5 shows results of incubating the $\alpha$-defensin HNP- 1 with the target organism $E$. coli in buffer without nutrients for $2 \mathrm{~h}$. These are the usual assay conditions for $\beta$-defensins. There was little or no growth of $E$. coli during the incubation without nutrients and no statistically significant killing by up to $30 \mu \mathrm{M}$ HNP-1. HNP-1 caused only a small loss of viability of $E$. coli under these conditions. The difference in results in Figures 4.1 and 4.5 explains why HNP-1 and other $\alpha$-defensins are usually assayed in dilute culture medium rather than in buffer without nutrients. These results are consistent with reports that HNP-1 kills only metabolically active bacteria (3). The 10 $\mathrm{mM}$ phosphate buffer does not provide $E$. coli with the nutrients needed to be metabolically active.

Figure 4.6 shows $\beta$-defensin HBD-3 was less effective against $E$. coli under these assay conditions compared with activity in dilute growth medium (Figure 4.2). However, $30 \mu \mathrm{M}$ HBD-3 killed $90 \%$ of the $E$. coli even under these assay conditions.

Figure 4.7 shows HNP-1 up to $30 \mu \mathrm{M}$ had no activity against $A$. $a$. in the buffer without nutrients. In contrast, Figure 4.8 shows HBD-3 was highly effective in killing A.a. under these assay conditions. With 5 to $10 \mu \mathrm{M}$ HBD-3, 90 to $99 \%$ killing was achieved.

The results show A.a. was resistant to HNP-1 and that HBD-3 was highly effective against $A$.a. regardless of the assay conditions. Therefore, our results confirm that $A . a$. is resistant to HNP-1 but not HBD-3. In addition, we found the presence or absence of nutrients had a significant effect on activity of HNP-1 and HBD-3 against $E$. coli but little effect on results with A.a. as the target bacteria.

\section{Activity of Synthetic Peptides}

Our second objective was to determine whether the additional amino acid residues at the N-terminus and C-terminus of HBD-3 account for the greater activity of HBD-3 against $A$.a. compared with HNP-1. To test effects of the N- and C-terminus of HBD-3, we used peptides originally described by Hoover et al. (60) and referred to as CHRG07 and CHRG01 (Figure 1.3). CHRG07 is a 17 amino acid peptide corresponding to the Nterminal region of HBD-3. CHRG01 is a 14 amino acid peptide corresponding to the $\mathrm{C}$ terminal region of HBD-3. In these synthetic peptides, serine $(\mathrm{S})$ replaces cysteine $(\mathrm{C})$ to prevent formation of disulfide bonds. We had these two peptides synthesized for this study. 


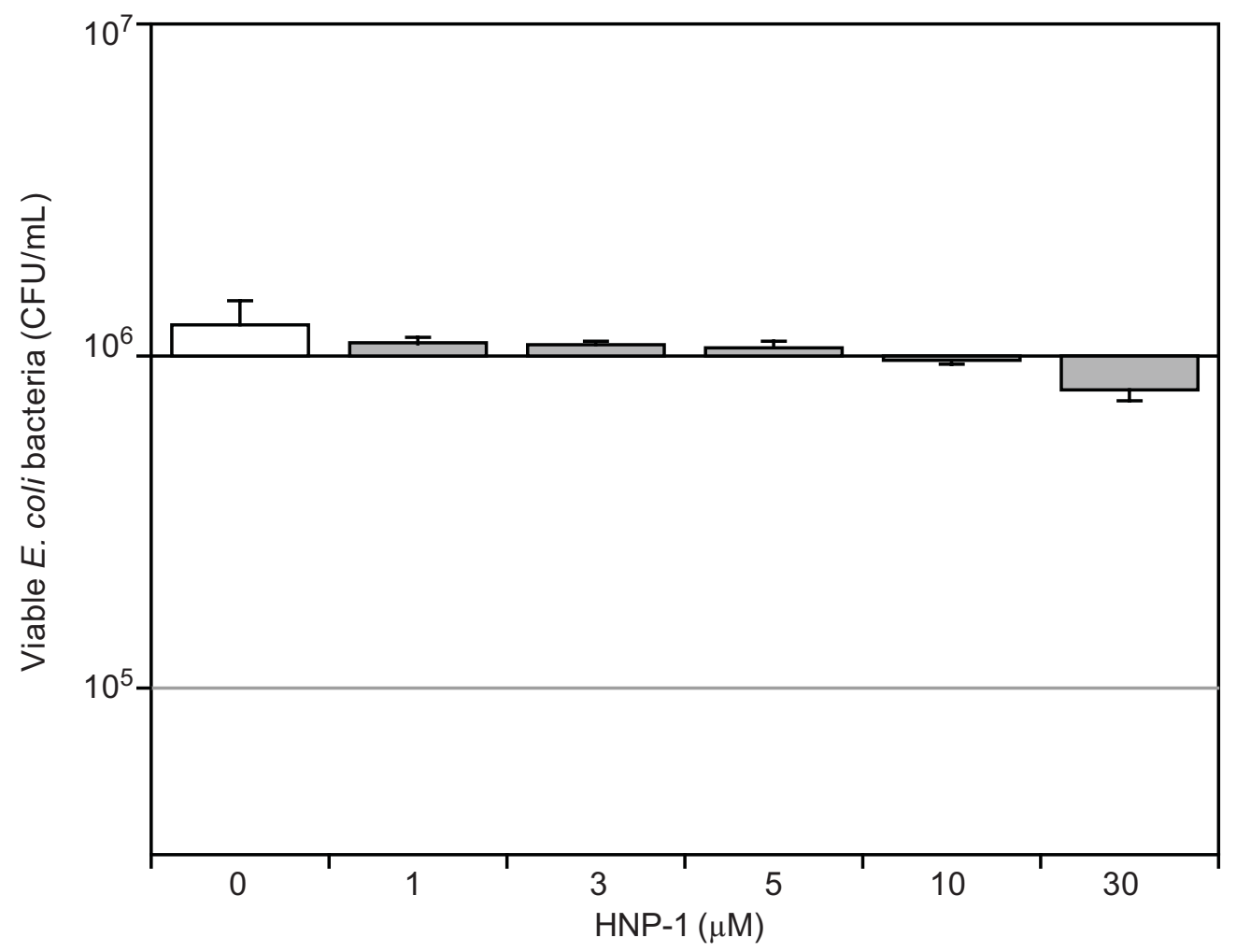

\begin{tabular}{lcccr}
\hline Conditions & $\begin{array}{c}\text { Viable bacteria } \\
\left(10^{6} \mathrm{CFU} / \mathrm{ml}\right)\end{array}$ & S.E. & $\mathrm{n}$ & P value \\
\hline Control $\left(2 \mathrm{~h}, 37^{\circ} \mathrm{C}\right)$ & 1.237 & 0.225 & 4 & - \\
$\mathrm{HNP}-1,1 \mu \mathrm{M}$ & 1.087 & 0.053 & 4 & 1.0 \\
$\mathrm{HNP}-1,3 \mu \mathrm{M}$ & 1.079 & 0.022 & 4 & 0.9 \\
$\mathrm{HNP}-1,5 \mu \mathrm{M}$ & 1.056 & 0.049 & 4 & 0.9 \\
$\mathrm{HNP}-1,10 \mu \mathrm{M}$ & 0.972 & 0.034 & 4 & 0.6 \\
$\mathrm{HNP}-1,30 \mu \mathrm{M}$ & 0.789 & 0.060 & 4 & 0.1 \\
\hline
\end{tabular}

Figure 4.5. HNP-1 does not kill $E$. coli in buffer

E. coli bacteria $\left(10^{6} / \mathrm{ml}\right)$ were incubated $2 \mathrm{~h}$ at $37^{\circ} \mathrm{C}$ in buffer without HNP-1 (control; white bar) or with 1 to $30 \mu \mathrm{M} \mathrm{HNP}-1$ (gray bars). 


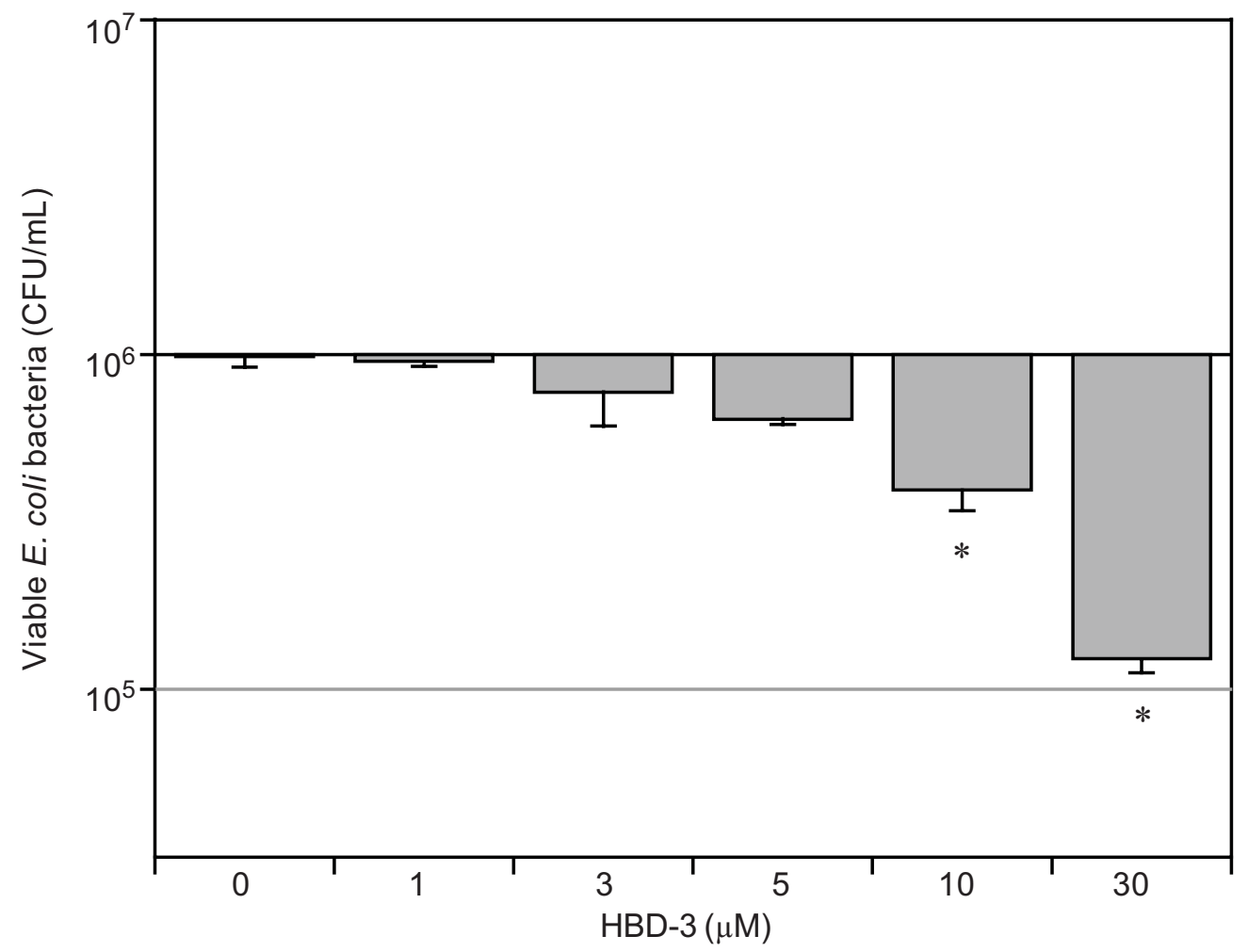

\begin{tabular}{lcccr}
\hline Conditions & $\begin{array}{c}\text { Viable bacteria } \\
\left(10^{6} \mathrm{CFU} / \mathrm{ml}\right)\end{array}$ & S.E. & $\mathrm{n}$ & P value \\
\hline Control $\left(2 \mathrm{~h}, 37^{\circ} \mathrm{C}\right)$ & 0.987 & 0.074 & 4 & - \\
HBD-3, $1 \mu \mathrm{M}$ & 0.951 & 0.033 & 4 & 1.0 \\
HBD-3, $3 \mu \mathrm{M}$ & 0.769 & 0.161 & 4 & 0.6 \\
HBD-3, $5 \mu \mathrm{M}$ & 0.642 & 0.025 & 4 & 0.1 \\
HBD-3, $10 \mu \mathrm{M}$ & 0.392 & 0.052 & 4 & $0.002^{*}$ \\
HBD-3, $30 \mu \mathrm{M}$ & 0.123 & 0.011 & 4 & $<0.0001^{*}$ \\
\hline
\end{tabular}

Figure 4.6. HBD-3 kills $E$. coli in buffer

E. coli bacteria $\left(10^{6} / \mathrm{ml}\right)$ were incubated $2 \mathrm{~h}$ at $37^{\circ} \mathrm{C}$ in buffer without HBD-3 (control; white bar) or with 1 to $30 \mu \mathrm{M}$ HBD-3 (gray bars).

* Significantly different from the control value without HBD-3. 


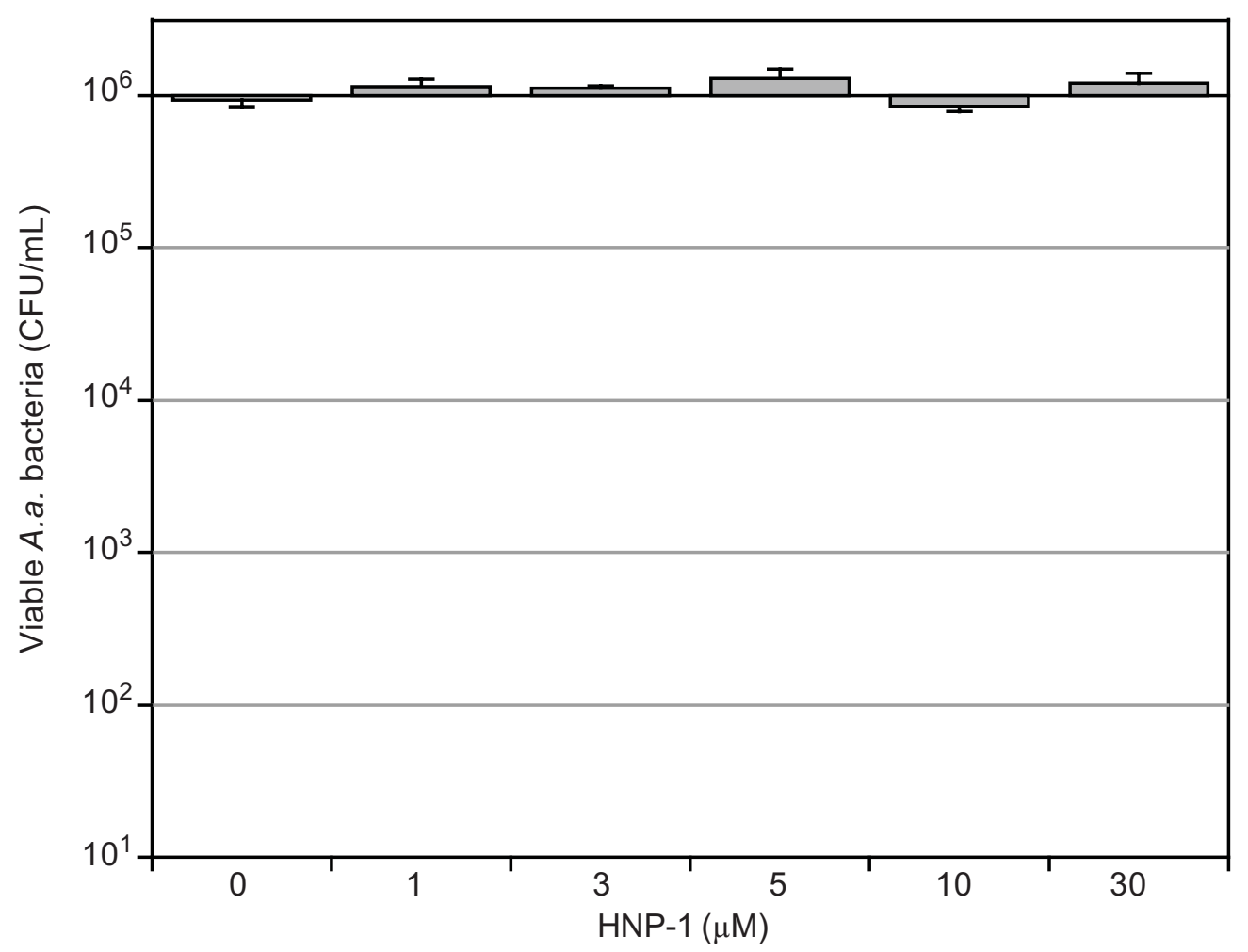

\begin{tabular}{lcccr}
\hline Conditions & $\begin{array}{c}\text { Viable bacteria } \\
\left(10^{6} \mathrm{CFU} / \mathrm{ml}\right)\end{array}$ & S.E. & $\mathrm{n}$ & P value \\
\hline Control $\left(2 \mathrm{~h}, 37^{\circ} \mathrm{C}\right)$ & 0.939 & 0.099 & 4 & - \\
HNP-1, $1 \mu \mathrm{M}$ & 1.161 & 0.126 & 4 & 0.9 \\
HNP-1, $3 \mu \mathrm{M}$ & 1.120 & 0.052 & 4 & 1.0 \\
HNP-1, $5 \mu \mathrm{M}$ & 1.303 & 0.178 & 4 & 0.6 \\
HNP-1, $10 \mu \mathrm{M}$ & 0.854 & 0.071 & 4 & 1.0 \\
HNP-1, $30 \mu \mathrm{M}$ & 1.216 & 0.183 & 4 & 0.8 \\
\hline
\end{tabular}

Figure 4.7. HNP-1 does not kill $A$. $a$. in buffer

A.a. bacteria $\left(10^{6} / \mathrm{ml}\right)$ were incubated $2 \mathrm{~h}$ at $37^{\circ} \mathrm{C}$ in buffer without HNP-1 (control; white bar) or with 1 to $30 \mu \mathrm{M} \mathrm{HNP}-1$ (gray bars). 


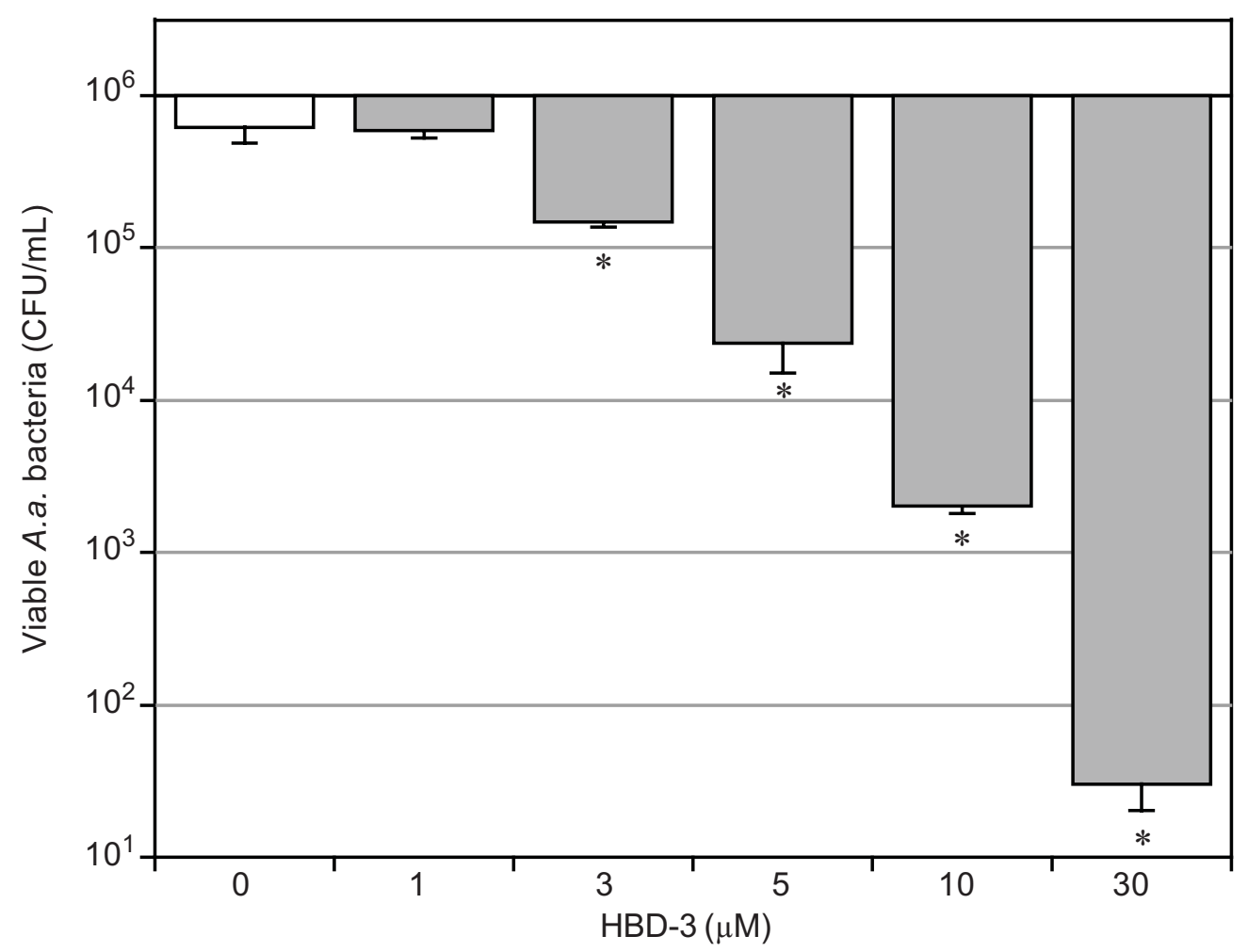

\begin{tabular}{lcccc} 
Conditions & $\begin{array}{c}\text { Viable bacteria } \\
\left(10^{6} \mathrm{CFU} / \mathrm{ml}\right)\end{array}$ & S.E. & $\mathrm{n}$ & P value \\
\hline Control $\left(2 \mathrm{~h}, 37^{\circ} \mathrm{C}\right)$ & 0.569 & 0.073 & 4 & - \\
HBD-3, $1 \mu \mathrm{M}$ & 0.438 & 0.096 & 4 & 0.7 \\
HBD-3, $3 \mu \mathrm{M}$ & 0.101 & 0.028 & 4 & $0.0003^{*}$ \\
HBD-3, $5 \mu \mathrm{M}$ & 0.021 & 0.004 & 4 & $<0.0001^{*}$ \\
HBD-3, $10 \mu \mathrm{M}$ & 0.003 & 0.001 & 4 & $<0.0001^{*}$ \\
HBD-3, $30 \mu \mathrm{M}$ & 0.000 & 0.000 & 4 & $<0.0001^{*}$ \\
\hline
\end{tabular}

Figure 4.8. HBD-3 kills $A$. $a$. in buffer

A.a. bacteria $\left(10^{6} / \mathrm{ml}\right)$ were incubated $2 \mathrm{~h}$ at $37^{\circ} \mathrm{C}$ in buffer without HBD-3 (control; white bar) or with 1 to $30 \mu \mathrm{M} \mathrm{HBD}-3$ (gray bars).

* Significantly different from the control value without HBD-3. 
To assay antibacterial activity, bacteria at $10^{6} \mathrm{CFU} / \mathrm{ml}$ were incubated $4 \mathrm{~h}$ in dilute culture medium at $37^{\circ} \mathrm{C}$ with increasing concentrations of CHRG07 or CHRG01. After the incubation, the number of live bacteria was determined by diluting, plating, and counting colonies.

Figure 4.9 compares the results of incubating $E$. coli with $5 \mu \mathrm{M}$ HBD-3 or with 1 to $100 \mu \mathrm{M}$ CHRG07 in dilute culture medium for $4 \mathrm{~h}$. When the bacteria were incubated without HBD-3 or CHRG07, the number of bacteria increased nearly 100-fold to about $10^{8} \mathrm{CFU} / \mathrm{mL}$. When $5 \mu \mathrm{M}$ HBD-3 was added at the beginning of the incubation, 90 to $99 \%$ of the bacteria were killed. CHRG07 at $1 \mu \mathrm{M}$ had no effect, but 3 to $5 \mu \mathrm{M}$ CHRG07 caused significant killing. CHRG07 at $10 \mu \mathrm{M}$ killed $>99.9 \%$ of the E. coli bacteria. Figure 4.10 shows results of incubating $E$. coli bacteria with $5 \mu \mathrm{M}$ HBD-3 or with the CHRG01 peptide. As little as $1 \mu \mathrm{M}$ CHRG01 caused significant growth inhibition, but $10 \mu \mathrm{M}$ CHRG01 was required for significant killing. CHRG01 at 10 to $30 \mu \mathrm{M}$ gave results similar to $5 \mu \mathrm{M}$ HBD-3. Both CHRG07 and CHRG01 killed E. coli, but higher levels of CHRG01 were required to achieve the same levels of killing.

The synthetic peptides CHRG07 and CHRG01 were also active against $A$.a., as shown in Figures 4.11 and 4.12. In the dilute culture medium, A.a. started at $10^{6} \mathrm{CFU} / \mathrm{ml}$ and the number increased nearly 4 -fold during the $4 \mathrm{~h}$ incubation. As a positive control, 5 $\mu \mathrm{M}$ HBD-3 was added and gave 90 to $99 \%$ killing of $A$.a. Figure 4.11 shows the effects of increasing concentrations of CHRG07. From 90 to $99 \%$ killing of $A$. $a$. was achieved at the 5 to $10 \mu \mathrm{M}$ concentrations, similar to results obtained with HBD-3. Figure 4.12 shows CHRG01 gave 90 to $99 \%$ killing of $A$.a. but at a much higher concentration of 30 to $100 \mu \mathrm{M}$.

Compared with the results shown for HBD-3 in Figures 4.2 and 4.4, results in Figures 4.9 and 4.11 show that the peptide CHRG07 was equal to HBD-3 in activity against E. coli and A.a. The C-terminal peptide CHRG01 (Figures 4.10 and 4.12) was much less active than HBD-3 against both E. coli and A.a. These results indicate that the hydrophobic residues near the N-terminus of HBD-3 are important for activity.

\section{HBD-3 Binding to Purified LPS}

Our third objective was to determine whether HBD-3 binds to LPS. We wanted to determine whether binding of the hydrophobic N-terminus of HBD-3 to the hydrophobic portion of LPS contributes to antimicrobial activity of HBD-3.

To assay antibacterial activity, bacteria at a concentration of $10^{6} \mathrm{CFU} / \mathrm{ml}$ were incubated at $37^{\circ} \mathrm{C}$ with $5 \mu \mathrm{M} \mathrm{HBD}-3$ and various concentrations of purified LPS. After the incubation, the number of live bacteria was measured by diluting, plating, and counting colonies. The purpose was to determine whether purified LPS absorbs HBD-3 and thus blocks killing of the bacteria by HBD-3. 


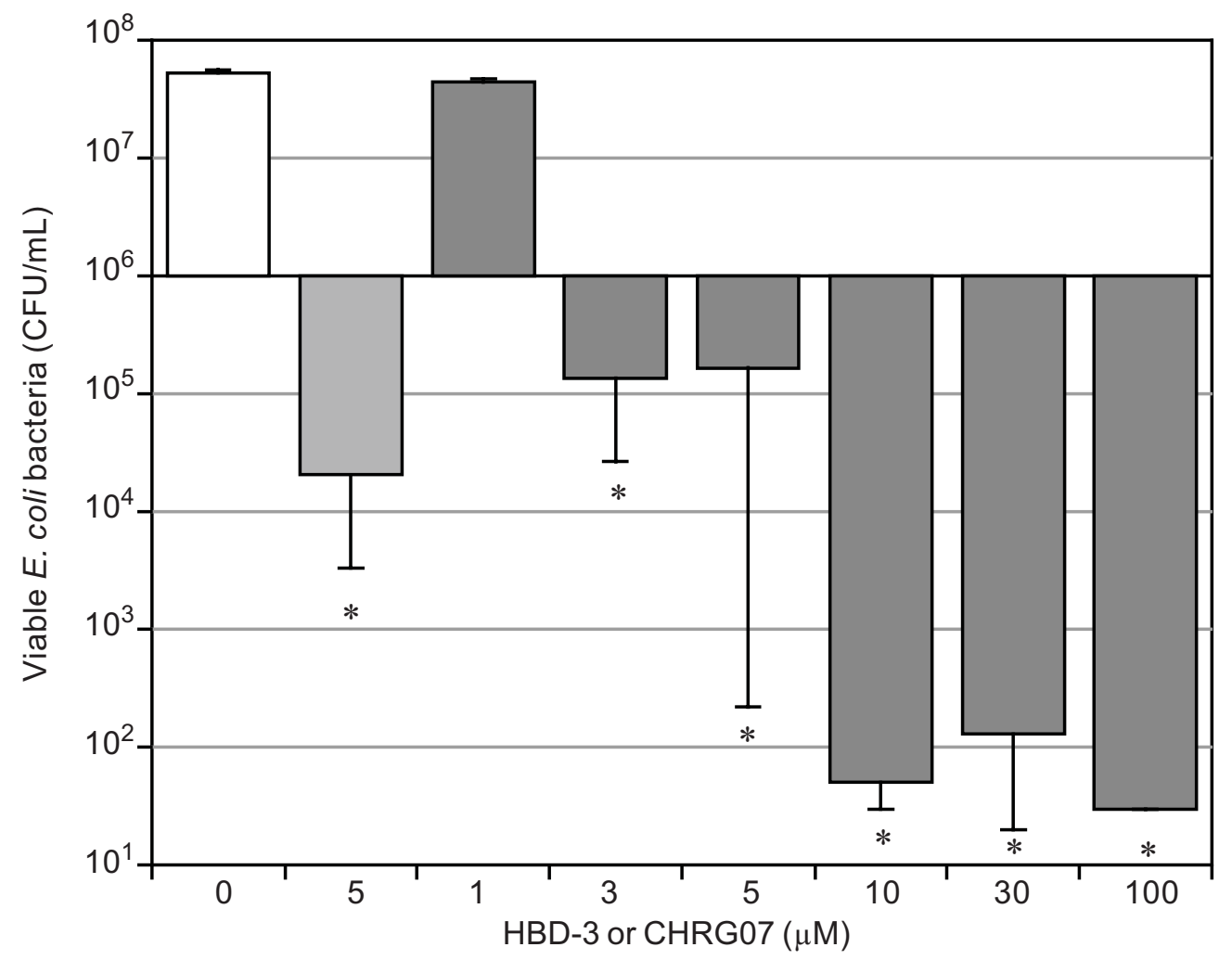

Conditions

Viable bacteria $\left(10^{6} \mathrm{CFU} / \mathrm{ml}\right)$

S.E.

P value

\begin{tabular}{lrrrr}
\hline Control $\left(4 \mathrm{~h}, 37^{\circ} \mathrm{C}\right)$ & 52.588 & 3.002 & 8 & - \\
HBD-3, $5 \mu \mathrm{M}$ & 0.020 & 0.017 & 8 & $<0.0001^{*}$ \\
CHRG07, $1 \mu \mathrm{M}$ & 44.324 & 2.854 & 4 & 0.3 \\
CHRG07, $3 \mu \mathrm{M}$ & 0.136 & 0.110 & 5 & $<0.0001^{*}$ \\
CHRG07, $5 \mu \mathrm{M}$ & 0.165 & 0.164 & 5 & $<0.0001^{*}$ \\
CHRG07, $10 \mu \mathrm{M}$ & 0.000 & 0.000 & 4 & $<0.0001^{*}$ \\
CHRG07, $30 \mu \mathrm{M}$ & 0.000 & 0.000 & 4 & $<0.0001^{*}$ \\
CHRG07, $100 \mu \mathrm{M}$ & 0.000 & 0.000 & 4 & $<0.0001^{*}$ \\
\hline
\end{tabular}

Figure 4.9. The peptide CHRG07 kills E.coli

E. coli bacteria $\left(10^{6} / \mathrm{ml}\right)$ were incubated $4 \mathrm{~h}$ at $37^{\circ} \mathrm{C}$ in dilute growth medium without HBD-3 or CHRG07 (control; white bar), with $5 \mu \mathrm{M}$ HBD-3 (gray bar), or with 1 to 100 $\mu \mathrm{M}$ CHRG07 (dark gray bars).

* Significantly different from the control value without HBD-3 or CHRG07. 


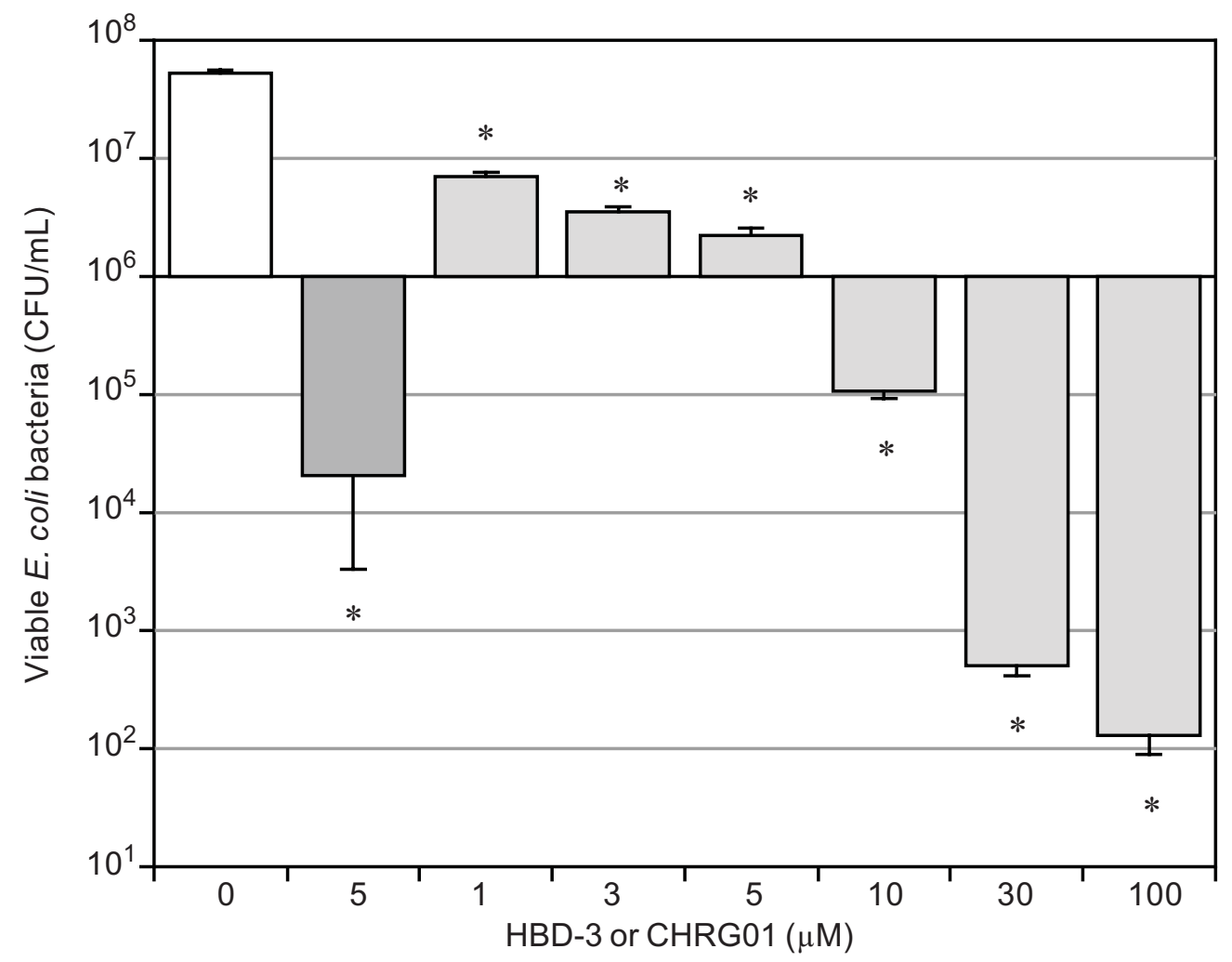

Conditions

Viable bacteria $\left(10^{6} \mathrm{CFU} / \mathrm{ml}\right)$

S.E. $\quad \mathrm{n} \quad \mathrm{P}$ value

\begin{tabular}{lcccc}
\hline Control $\left(4 \mathrm{~h}, 37^{\circ} \mathrm{C}\right)$ & 52.588 & 3.002 & 8 & - \\
HBD-3, $5 \mu \mathrm{M}$ & 0.020 & 0.017 & 8 & $<0.0001^{*}$ \\
CHRG01, $1 \mu \mathrm{M}$ & 7.038 & 0.589 & 4 & $<0.0001^{*}$ \\
CHRG01, $3 \mu \mathrm{M}$ & 3.526 & 0.327 & 4 & $<0.0001^{*}$ \\
CHRG01, $5 \mu \mathrm{M}$ & 2.211 & 0.356 & 4 & $<0.0001^{*}$ \\
CHRG01, $10 \mu \mathrm{M}$ & 0.107 & 0.014 & 4 & $<0.0001^{*}$ \\
CHRG01, $30 \mu \mathrm{M}$ & 0.001 & 0.000 & 4 & $<0.0001^{*}$ \\
CHRG01, $100 \mu \mathrm{M}$ & 0.000 & 0.000 & 4 & $<0.0001^{*}$ \\
\hline
\end{tabular}

Figure 4.10. The peptide CHRG01 kills $E$. coli

E. coli bacteria $\left(10^{6} / \mathrm{ml}\right)$ were incubated $4 \mathrm{~h}$ at $37^{\circ} \mathrm{C}$ in dilute culture medium without HBD-3 or CHRG01 (control; white bar), with $5 \mu \mathrm{M} \mathrm{HBD-3} \mathrm{(dark} \mathrm{gray} \mathrm{bar),} \mathrm{or} \mathrm{with} 1$ to $100 \mu \mathrm{M}$ CHRG01 (light gray bars).

* Significantly different from the control value without HBD-3 or CHRG01. 


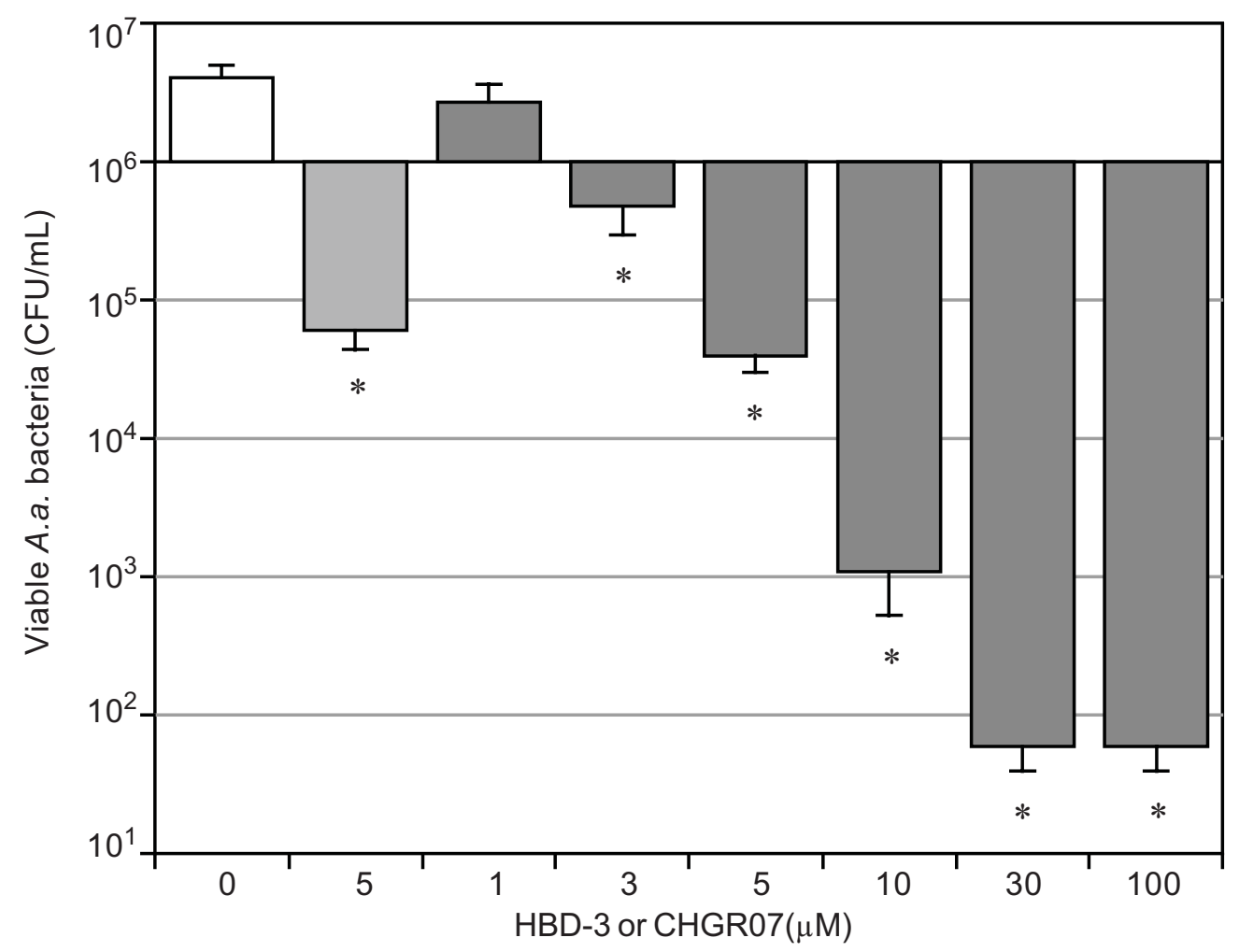

Conditions

Viable bacteria (10 $\left.{ }^{6} \mathrm{CFU} / \mathrm{ml}\right)$

S.E.

n P value

\begin{tabular}{llllc}
\hline Control $\left(4 \mathrm{~h}, 37^{\circ} \mathrm{C}\right)$ & 4.094 & 0.888 & 8 & - \\
HBD-3, $5 \mu \mathrm{M}$ & 0.061 & 0.017 & 8 & $0.0001^{*}$ \\
CHRG07, $1 \mu \mathrm{M}$ & 2.699 & 0.934 & 4 & 1.0 \\
CHRG07, $3 \mu \mathrm{M}$ & 0.478 & 0.181 & 4 & $0.023^{*}$ \\
CHRG07, $5 \mu \mathrm{M}$ & 0.040 & 0.010 & 4 & $0.005^{*}$ \\
CHRG07, $10 \mu \mathrm{M}$ & 0.001 & 0.001 & 4 & $0.004^{*}$ \\
CHRG07, $30 \mu \mathrm{M}$ & 0.000 & 0.000 & 4 & $0.004^{*}$ \\
CHRG07, $100 \mu \mathrm{M}$ & 0.000 & 0.000 & 4 & $0.004^{*}$ \\
\hline
\end{tabular}

\section{Figure 4.11. The peptide CHRG07 kills $A . a$.}

A.a. bacteria $\left(10^{6} / \mathrm{ml}\right)$ were incubated $4 \mathrm{~h}$ at $37^{\circ} \mathrm{C}$ in dilute culture medium without HBD-3 (control; white bar), with $5 \mu \mathrm{M} \mathrm{HBD}-3$ (gray bar), or with 1 to $100 \mu \mathrm{M}$ CHRG07 (dark gray bars).

* Significantly different from the control value without HBD-3 or CHRG07. 


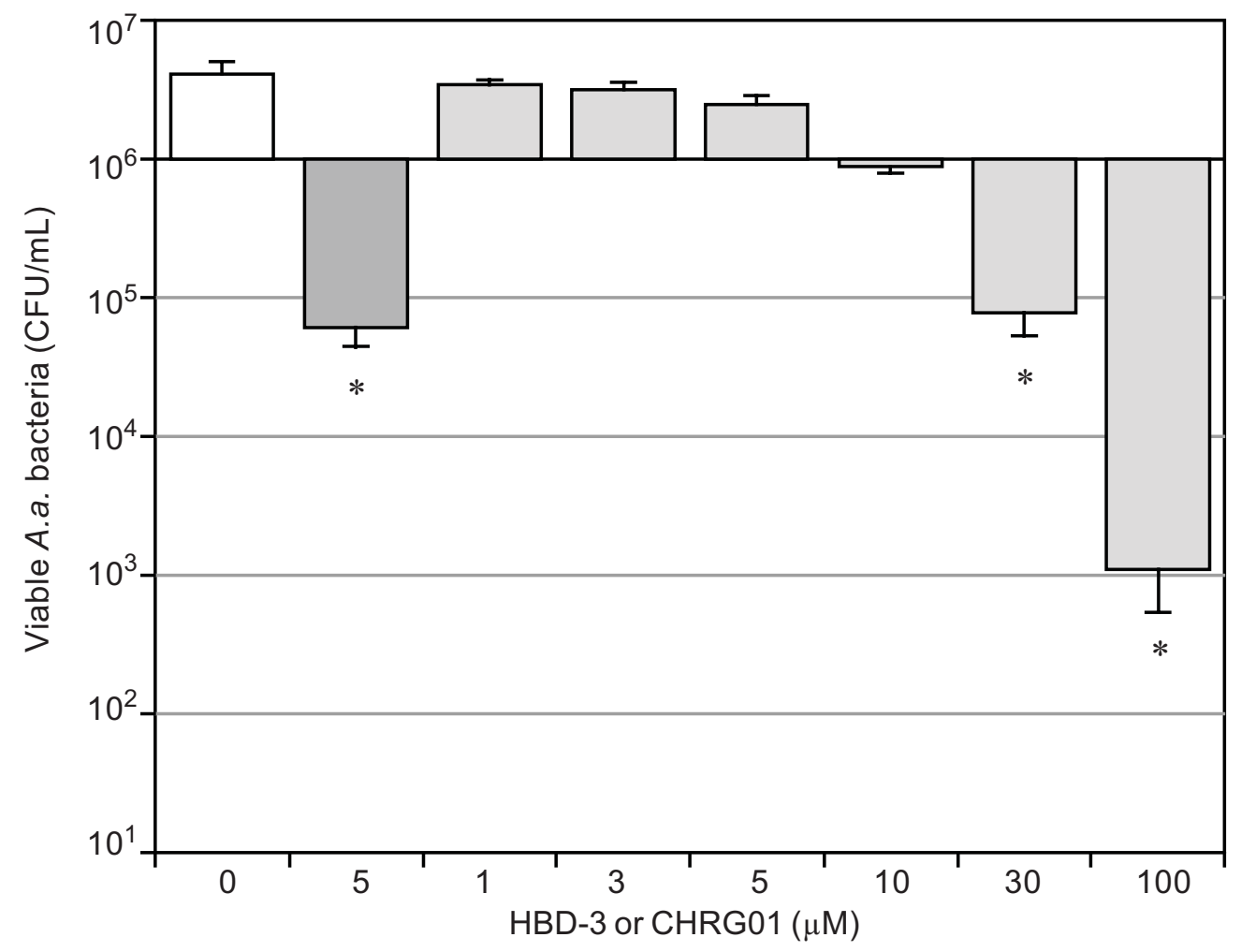

\begin{tabular}{lccrr} 
Conditions & $\begin{array}{c}\text { Viable bacteria } \\
\left(10^{6} \mathrm{CFU} / \mathrm{ml}\right)\end{array}$ & S.E. & $\mathrm{n}$ & P value \\
\hline Control $\left(4 \mathrm{~h}, 37^{\circ} \mathrm{C}\right)$ & 4.094 & 0.888 & 8 & - \\
HBD-3, $5 \mu \mathrm{M}$ & 0.061 & 0.017 & 8 & 0.0001 \\
CHRG01, $1 \mu \mathrm{M}$ & 3.410 & 0.333 & 4 & 1.0 \\
CHRG01, $3 \mu \mathrm{M}$ & 3.140 & 0.432 & 4 & 1.0 \\
CHRG01, $5 \mu \mathrm{M}$ & 2.464 & 0.411 & 4 & 0.9 \\
CHRG01, $10 \mu \mathrm{M}$ & 0.875 & 0.085 & 4 & 0.08 \\
CHRG01,30 $3 \mathrm{M}$ & 0.078 & 0.025 & 4 & $<0.0055^{*}$ \\
CHRG01, $100 \mu \mathrm{M}$ & 0.001 & 0.001 & 4 & $<0.0041^{*}$ \\
\hline
\end{tabular}

Figure 4.12. The peptide CHRG01 kills $A . a$.

A.a. bacteria $\left(10^{6} / \mathrm{ml}\right)$ were incubated $4 \mathrm{~h}$ at $37^{\circ} \mathrm{C}$ in dilute culture medium without HBD-3 or CHRG01 (control; white bar), with $5 \mu \mathrm{M}$ HBD-3 (dark gray bar), or with 1 to $100 \mu \mathrm{M}$ CHRG01 (light gray bars).

* Significantly different from the control value without HBD-3 or CHRG01. 
Figure 4.13 shows the target bacteria $E$. coli started at $10^{6} \mathrm{CFU} / \mathrm{ml}$ and increased nearly 100 fold to about $10^{8} \mathrm{CFU} / \mathrm{ml}$ during the $4 \mathrm{~h}$ incubation without HBD-3 in dilute culture medium. When $5 \mu \mathrm{M} E$. coli LPS was added, there was no effect of LPS on growth of $E$. coli. When $5 \mu \mathrm{M}$ HBD-3 was added, HBD-3 caused 90 to $99 \%$ killing. When increasing concentrations of $E$. coli LPS were added along with $5 \mu \mathrm{M}$ HBD-3, LPS blocked the activity of HBD-3. Results in Figure 4.13 show complete blocking of $5 \mu \mathrm{M}$ HBD- 3 by $5 \mu \mathrm{M}$ LPS. These results suggest binding of one HBD-3 molecule to each molecule of LPS. Figure 4.14 shows that very similar results were obtained using purified A.a. LPS to block HBD-3 activity against the target E. coli. A.a. LPS blocked HBD-3 killing of E. coli at a 1:1 ratio of HBD-3 to LPS.

Similar experiments were performed testing the ability of purified E. coli or A.a. LPS to block HBD-3 killing of $A$. $a$. under the usual assay conditons for $\beta$-defensins. Figure 4.15 shows the target bacteria $A$.a. started at $10^{6} \mathrm{CFU} / \mathrm{ml}$ and did not increase in number during a $2 \mathrm{~h}$ incubation in buffer without nutrients. When $5 \mu \mathrm{M} E$. coli LPS was added, it had no effect on viability of A.a. HBD-3 alone at $5 \mu \mathrm{M}$ gave 90 to $99 \%$ killing of $A$. a. When increasing concentrations of $E$. coli LPS were added, LPS blocked the activity of HBD-3. Results in Figure 4.15 show complete blocking of $5 \mu \mathrm{M}$ HBD- 3 by 5 $\mu \mathrm{M}$ LPS or a 1:1 ratio of HBD-3 to LPS. Very similar results were obtained using A.a. LPS to block HBD-3 activity against the target $A$. $a$, , as seen in Figure 4.16. A.a. LPS alone had no effect on viability. A.a. LPS was able to absorb HBD-3 and block killing of A.a. by HBD-3.

\section{HBD-3 Binding to Deacyl-LPS but Not Lipid A}

To determine whether the hydrophobic fatty acids of the lipid A portion of LPS were important for binding HBD-3, we examined the ability of deacyl-LPS to block HBD-3 activity. Figures 4.17 and 4.18 show the effects of adding deacyl-LPS on the activity of $5 \mu \mathrm{M}$ HBD-3 against $E$. coli and A.a. Deacyl-LPS at $10 \mu \mathrm{M}$ had no significant effect on growth of $E$. coli during a $4 \mathrm{~h}$ incubation in dilute culture medium (Figure 4.17). Deacyl-LPS was able to absorb HBD-3 and block killing of the target organism E. coli. Killing was blocked by 5 to $10 \mu \mathrm{M}$ deacyl-LPS, at a HBD-3 to deacyl-LPS ratio of about 1:1. Similar results were obtained with A.a. as the target bacteria (Figure 4.18). The number of $A$.a. bacteria did not increase during a $2 \mathrm{~h}$ incubation in buffer without nutrients. Deacyl-LPS had no significant effect on $A$. $a$. viability. HBD-3 at $5 \mu \mathrm{M}$ caused nearly $99 \%$ killing of $A$. $a$. Killing by $5 \mu \mathrm{M}$ HBD-3 was blocked by about $5 \mu \mathrm{M}$ deacylLPS. These results indicate the hydrophobic fatty acids of LPS were not needed for binding of HBD-3 to LPS.

To confirm that HBD-3 did not bind to the hydrophobic lipid A portion of LPS, we tested the ability of purified lipid A to block killing by HBD-3. Figures 4.19 and 4.20 show that purified lipid A at concentrations up to $10 \mu \mathrm{M}$ did not have a statistically significant effect on killing of $E$. coli or A.a. by $5 \mu \mathrm{M}$ HBD-3. There was some effect at higher concentrations of lipid A, but lipid A did not block killing even at these higher 


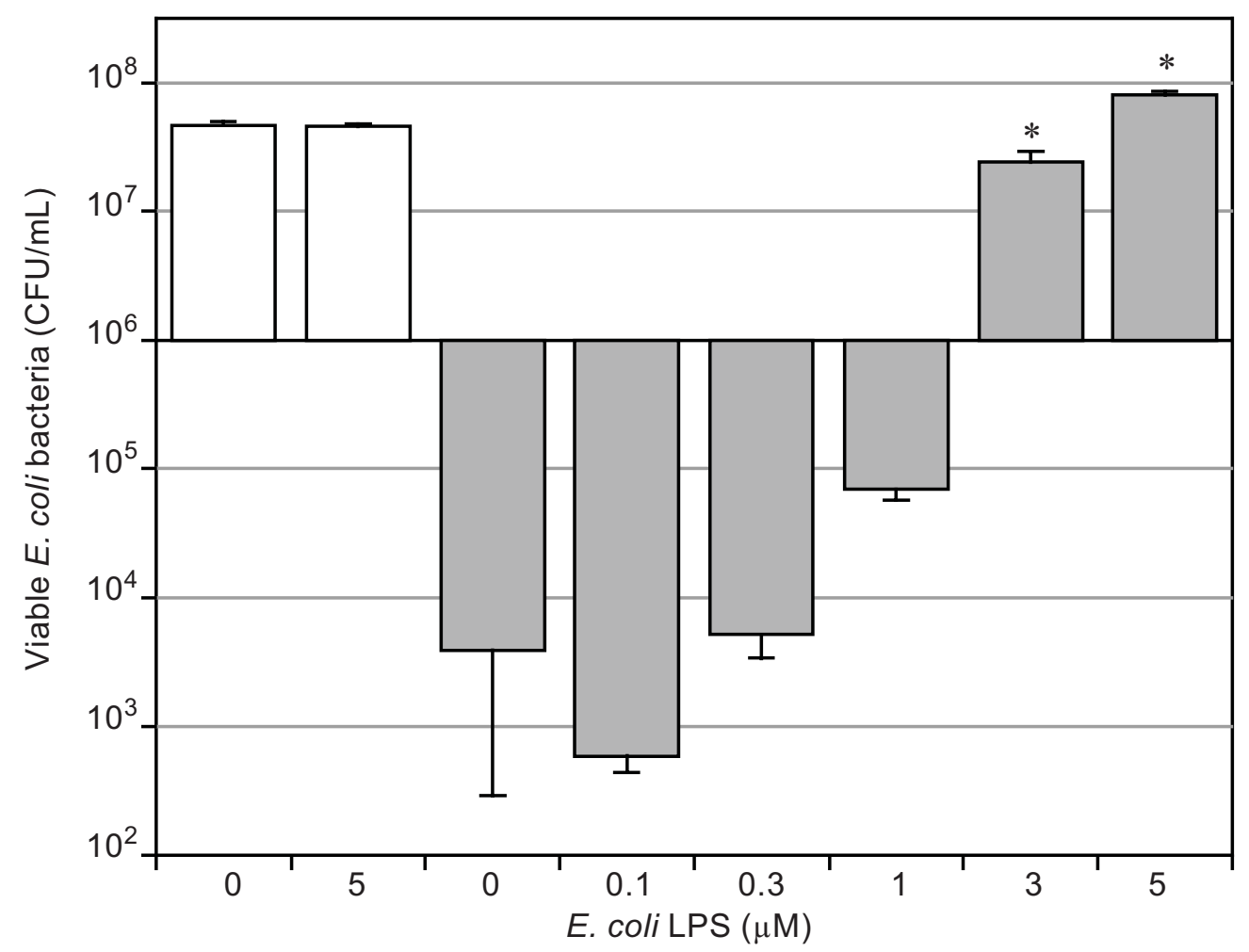

Conditions

Viable bacteria $\left(10^{6} \mathrm{CFU} / \mathrm{ml}\right)$

S.E.

n P value

\begin{tabular}{lrrrr}
\hline Control $\left(4 \mathrm{~h}, 37^{\circ} \mathrm{C}\right)$ & 47.071 & 3.519 & 8 & - \\
$5 \mu \mathrm{M}$ E. coli LPS & 45.679 & 2.228 & 4 & - \\
$5 \mu \mathrm{M} \mathrm{HBD}-3$ & 0.004 & 0.004 & 8 & - \\
$5 \mu \mathrm{M} \mathrm{HBD}-3+0.1 \mu \mathrm{M}$ E. coli LPS & 0.001 & 0.000 & 4 & 1.0 \\
$5 \mu \mathrm{M} \mathrm{HBD}-3+0.3 \mu \mathrm{M}$ E. coli LPS & 0.005 & 0.002 & 4 & 1.0 \\
$5 \mu \mathrm{M} \mathrm{HBD}-3+1 \mu \mathrm{M}$ E. coli LPS & 0.070 & 0.012 & 4 & 1.0 \\
$5 \mu \mathrm{M}$ HBD-3 $+3 \mu \mathrm{M}$ E. coli LPS & 24.345 & 4.890 & 4 & $0.02^{*}$ \\
$5 \mu \mathrm{M} \mathrm{HBD}-3+5 \mu \mathrm{M}$ E. coli LPS & 80.465 & 5.175 & 4 & $<0.0001^{*}$ \\
\hline
\end{tabular}

Figure 4.13. E. coli LPS blocks HBD-3 killing of $E$. coli

E. coli bacteria $\left(10^{6} / \mathrm{ml}\right)$ were incubated $4 \mathrm{~h}$ at $37^{\circ} \mathrm{C}$ in dilute culture medium with 0 or 5 $\mu \mathrm{M}$ E. coli LPS then diluted and plated (white bars). Alternatively, the bacteria were incubated with $5 \mu \mathrm{M}$ HBD-3 and various levels of E. coli LPS (gray bars).

* Significantly different from the value with HBD-3 alone. 


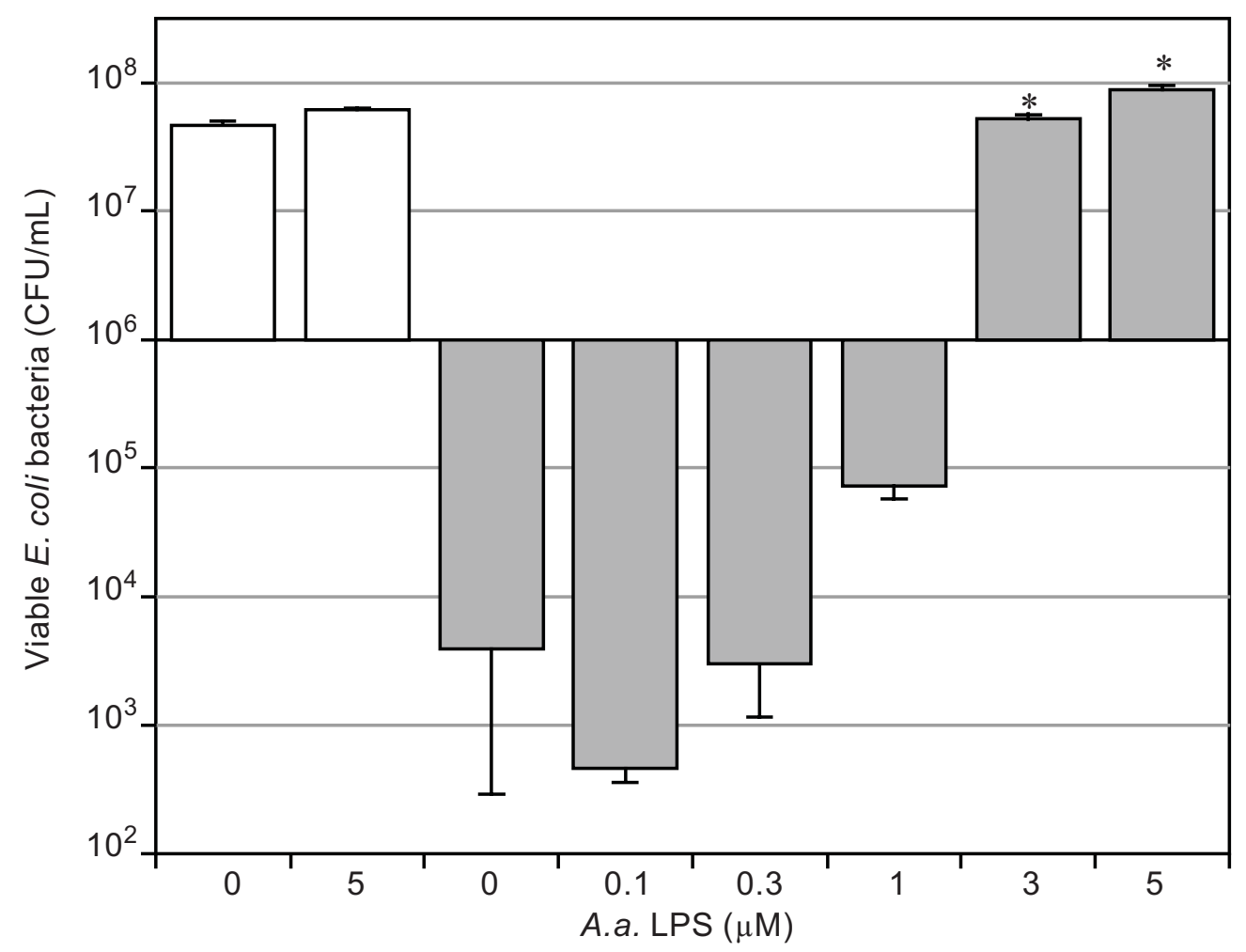

Conditions

Viable bacteria $\left(10^{6} \mathrm{CFU} / \mathrm{ml}\right)$

S.E.

n P value

\begin{tabular}{lrrrr}
\hline Control $\left(4 \mathrm{~h}, 37^{\circ} \mathrm{C}\right)$ & 47.070 & 3.519 & 8 & - \\
$5 \mu \mathrm{M}$ A.a. LPS & 61.246 & 2.411 & 4 & - \\
$5 \mu \mathrm{M} \mathrm{HBD}-3$ & 0.004 & 0.004 & 8 & - \\
$5 \mu \mathrm{M} \mathrm{HBD}-3+0.1 \mu \mathrm{M}$ A.a. LPS & 0.000 & 0.000 & 4 & 1.0 \\
$5 \mu \mathrm{M} \mathrm{HBD}-3+0.3 \mu \mathrm{M}$ A.a. LPS & 0.003 & 0.002 & 4 & 1.0 \\
$5 \mu \mathrm{M} \mathrm{HBD}-3+1 \mu \mathrm{M}$ A.a. LPS & 0.073 & 0.015 & 4 & 1.0 \\
$5 \mu \mathrm{M} \mathrm{HBD}-3+3 \mu \mathrm{M}$ A.a. LPS & 52.220 & 4.591 & 4 & $<0.0001^{*}$ \\
$5 \mu \mathrm{M} \mathrm{HBD}-3+5 \mu \mathrm{M}$ A.a. LPS & 87.379 & 8.659 & 4 & $<0.0001^{*}$ \\
\hline
\end{tabular}

Figure 4.14. A.a. LPS blocks HBD-3 killing of $E$. coli

E. coli bacteria $\left(10^{6} / \mathrm{ml}\right)$ were incubated $4 \mathrm{~h}$ at $37^{\circ} \mathrm{C}$ in dilute culture medium with 0 or 5 $\mu \mathrm{M}$ A.a. LPS then diluted and plated (white bars). Alternatively, the bacteria were incubated with $5 \mu \mathrm{M} \mathrm{HBD}-3$ and various levels of $A$. $a$. LPS (gray bars).

* Significantly different from the value with HBD-3 alone. 


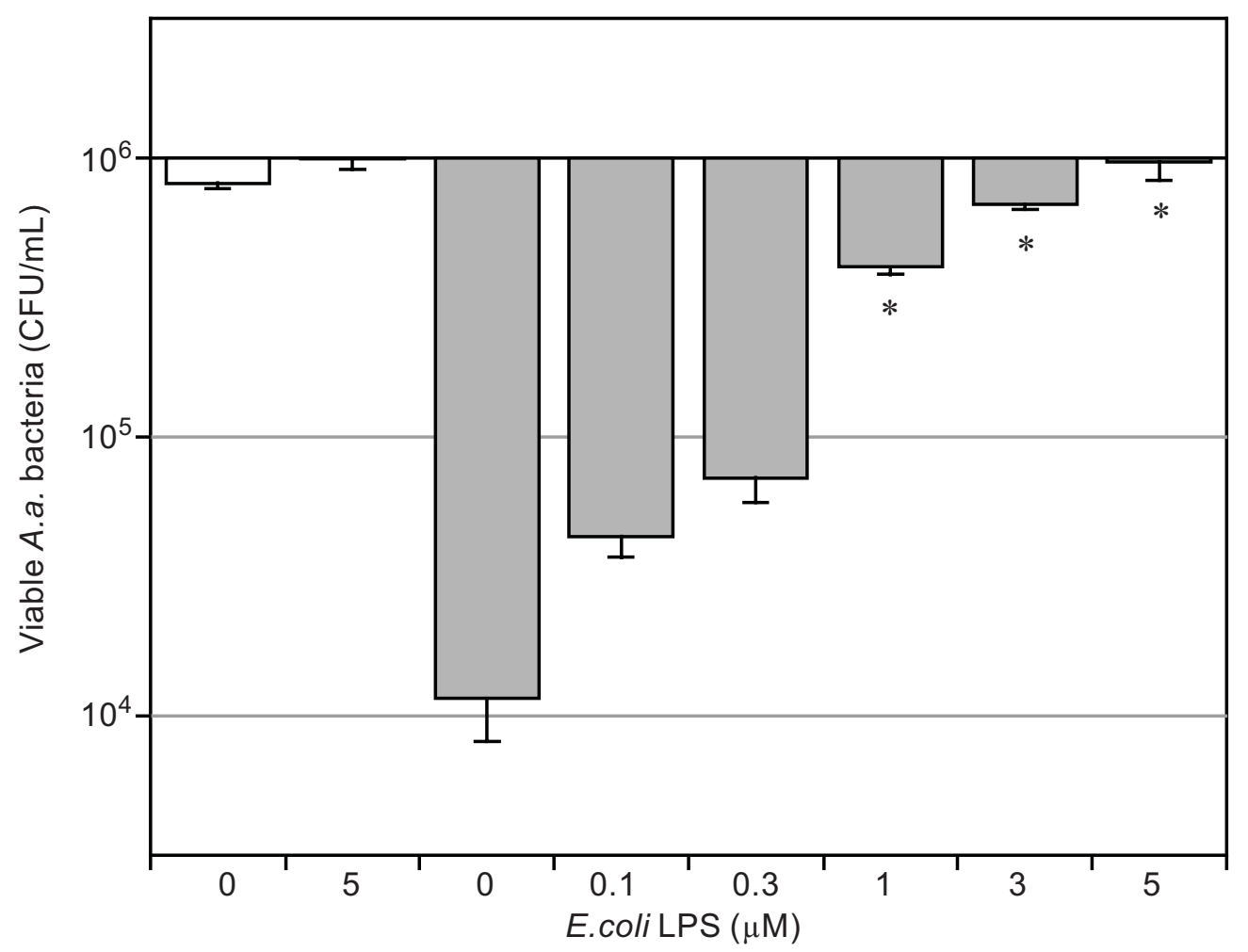

Conditions

Viable bacteria $\left(10^{6} \mathrm{CFU} / \mathrm{ml}\right)$

S.E. $\quad \mathrm{n} \quad$ P value

Control $\left(2 \mathrm{~h}, 37^{\circ} \mathrm{C}\right)$

0.761

0.023

10

$5 \mu \mathrm{M}$ E. coli LPS

0.995

0.089

4

$5 \mu \mathrm{M}$ HBD-3

0.009

0.002

10

$5 \mu \mathrm{M}$ HBD $-3+0.1 \mu \mathrm{M}$ E. coli LPS 0.044

0.007

4

1.0

$5 \mu \mathrm{M}$ HBD $-3+0.3 \mu \mathrm{M}$ E. coli $\mathrm{LPS} \quad 0.071$

0.013

4

1.0

$5 \mu \mathrm{M}$ HBD- $3+1 \mu \mathrm{M}$ E. coli LPS

0.407

0.025

4

$0.003^{*}$

$5 \mu \mathrm{M}$ HBD-3 $+3 \mu \mathrm{M}$ E. coli. LPS

0.682

0.030

$4<0.0001^{*}$

$5 \mu \mathrm{M}$ HBD $-3+5 \mu \mathrm{M}$ E. coli $\mathrm{LPS}$

0.965

0.134

4

$<0.0001^{*}$

\section{Figure 4.15. E. coli LPS blocks HBD-3 killing of A.a.}

A.a. bacteria $\left(10^{6} / \mathrm{mL}\right)$ with 0 or $5 \mu \mathrm{M} \mathrm{E}$. coli LPS were incubated $2 \mathrm{~h}$ at $37^{\circ} \mathrm{C}$ in buffer then diluted and plated (white bars). Alternatively, the bacteria were incubated with $5 \mu \mathrm{M}$ HBD-3 and various levels of $E$. coli LPS (gray bars).

* Significantly different from the value with HBD-3 alone. 


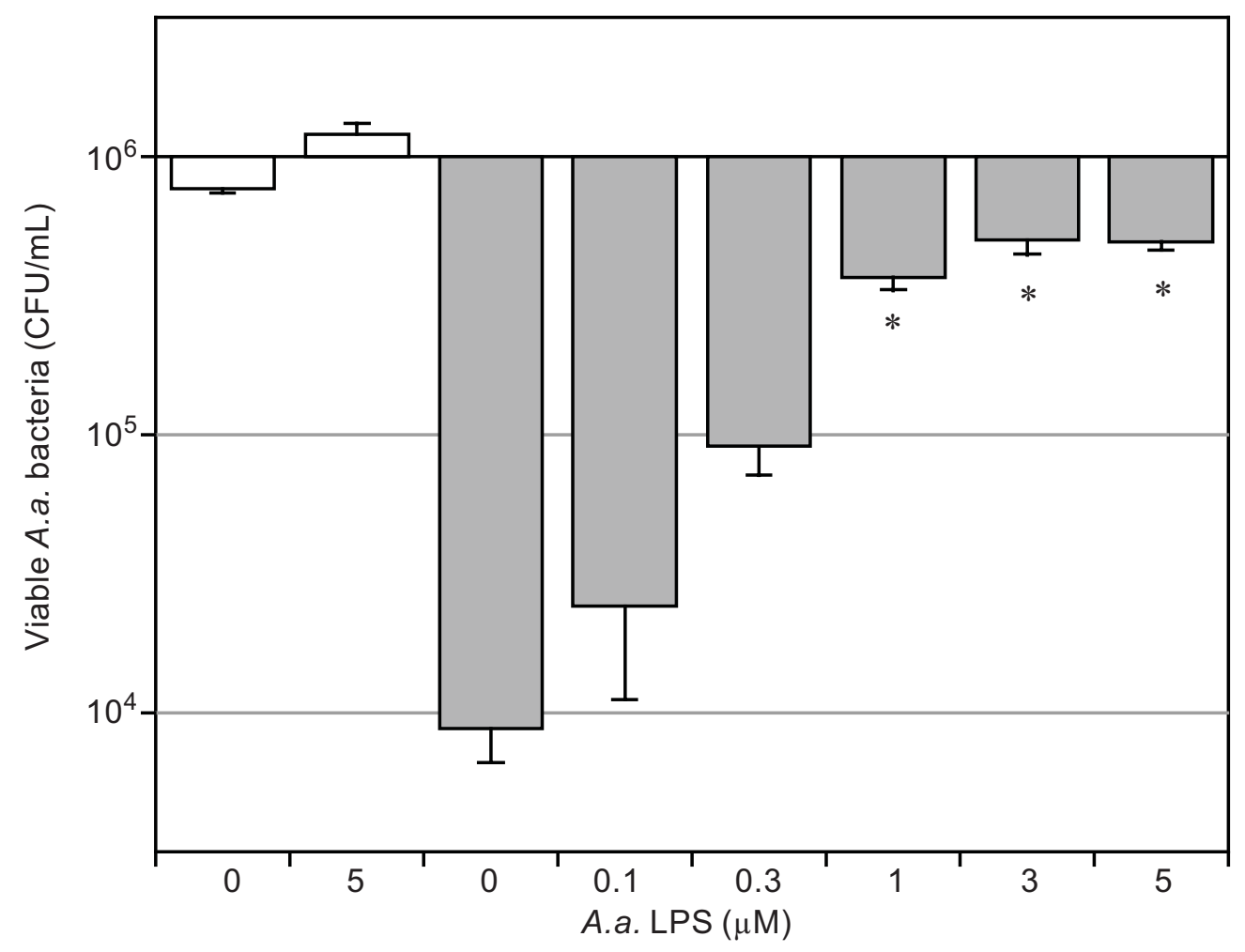

Conditions

Viable bacteria (10 $\left.{ }^{6} \mathrm{CFU} / \mathrm{ml}\right)$

S.E.

n P value

\begin{tabular}{|c|c|c|c|c|}
\hline Control $\left(2 \mathrm{~h}, 37^{\circ} \mathrm{C}\right)$ & 0.761 & 0.023 & 10 & - \\
\hline $5 \mu \mathrm{M}$ A.a. LPS & 1.199 & 0.116 & 4 & - \\
\hline $5 \mu \mathrm{M} \mathrm{HBD}-3$ & 0.009 & 0.002 & 10 & - \\
\hline $5 \mu \mathrm{M} \mathrm{HBD}-3+0.1 \mu \mathrm{M}$ A.a. LPS & 0.024 & 0.013 & 4 & 1.0 \\
\hline $5 \mu \mathrm{M} \mathrm{HBD}-3+0.3 \mu \mathrm{M}$ A.a. LPS & 0.091 & 0.019 & 4 & 1.0 \\
\hline $5 \mu \mathrm{M} \mathrm{HBD}-3+1 \mu \mathrm{M} A . a$. LPS & 0.368 & 0.038 & 6 & $0.0017^{*}$ \\
\hline $5 \mu \mathrm{M}$ HBD $-3+3 \mu \mathrm{M}$ A.a. LPS & 0.502 & 0.058 & 6 & $<0.0001^{*}$ \\
\hline $5 \mu \mathrm{M} \mathrm{HBD}-3+5 \mu \mathrm{M}$ A.a. LPS & 0.494 & 0.034 & 4 & $<0.0001^{*}$ \\
\hline
\end{tabular}

Figure 4.16. A.a. LPS blocks HBD-3 killing of $A . a$.

A.a. bacteria $\left(10^{6} / \mathrm{ml}\right)$ with 0 or $5 \mu \mathrm{M} A$. a. LPS were incubated $2 \mathrm{~h}$ at $37^{\circ} \mathrm{C}$ in buffer witout nutrients then diluted and plated (white bars). Alternatively, the bacteria were incubated with $5 \mu \mathrm{M} \mathrm{HBD}-3$ and various levels of $A$. $a$. LPS (gray bars).

* Significantly different from the value with HBD-3 alone. 


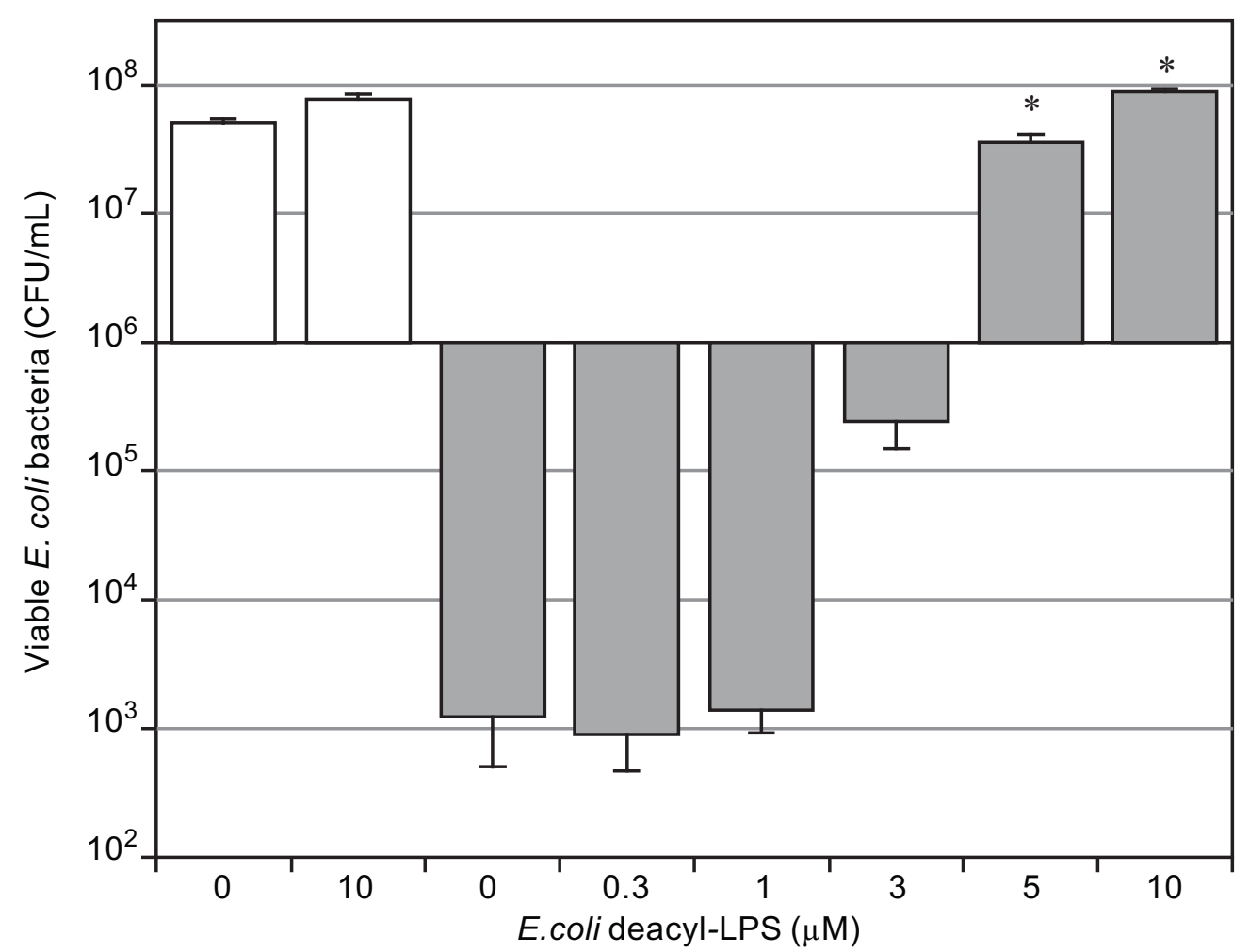

Conditions

Viable bacteria $\left(10^{6} \mathrm{CFU} / \mathrm{ml}\right)$

S.E.

n P value

\begin{tabular}{lrrrr}
\hline Control $\left(4 \mathrm{~h}, 37^{\circ} \mathrm{C}\right)$ & 50.294 & 4.433 & 8 & - \\
$10 \mu \mathrm{M}$ deacyl-LPS & 77.226 & 6.913 & 4 & - \\
$5 \mu \mathrm{M}$ HBD-3 & 0.001 & 0.001 & 8 & - \\
$5 \mu \mathrm{M}$ HBD-3 $+0.3 \mu \mathrm{M}$ deacyl-LPS & 0.001 & 0.000 & 4 & 1.0 \\
$5 \mu \mathrm{M}$ HBD-3 $+1 \mu \mathrm{M}$ deacyl-LPS & 0.001 & 0.000 & 4 & 1.0 \\
$5 \mu \mathrm{M}$ HBD-3 $+3 \mu \mathrm{M}$ deacyl-LPS & 0.243 & 0.095 & 4 & 1.0 \\
$5 \mu \mathrm{M}$ HBD-3 $+5 \mu \mathrm{M}$ deacyl-LPS & 35.583 & 5.718 & 4 & $<0.0001^{*}$ \\
$5 \mu \mathrm{M}$ HBD-3 $+10 \mu \mathrm{M}$ deacyl-LPS & 87.865 & 4.535 & 4 & $<0.0001^{*}$ \\
\hline
\end{tabular}

Figure 4.17. Deacyl-LPS blocks HBD-3 killing of $E$. coli

E. coli bacteria $\left(10^{6} / \mathrm{ml}\right)$ with 0 or $10 \mu \mathrm{M}$ deacyl-LPS were incubated $4 \mathrm{~h}$ at $37^{\circ} \mathrm{C}$ in dilute culture medium then diluted and plated (white bars). Alternatively, the bacteria were incubated with $5 \mu \mathrm{M}$ HBD-3 and various levels of deacyl-LPS (gray bars).

* Significantly different from the value with HBD-3 alone. 


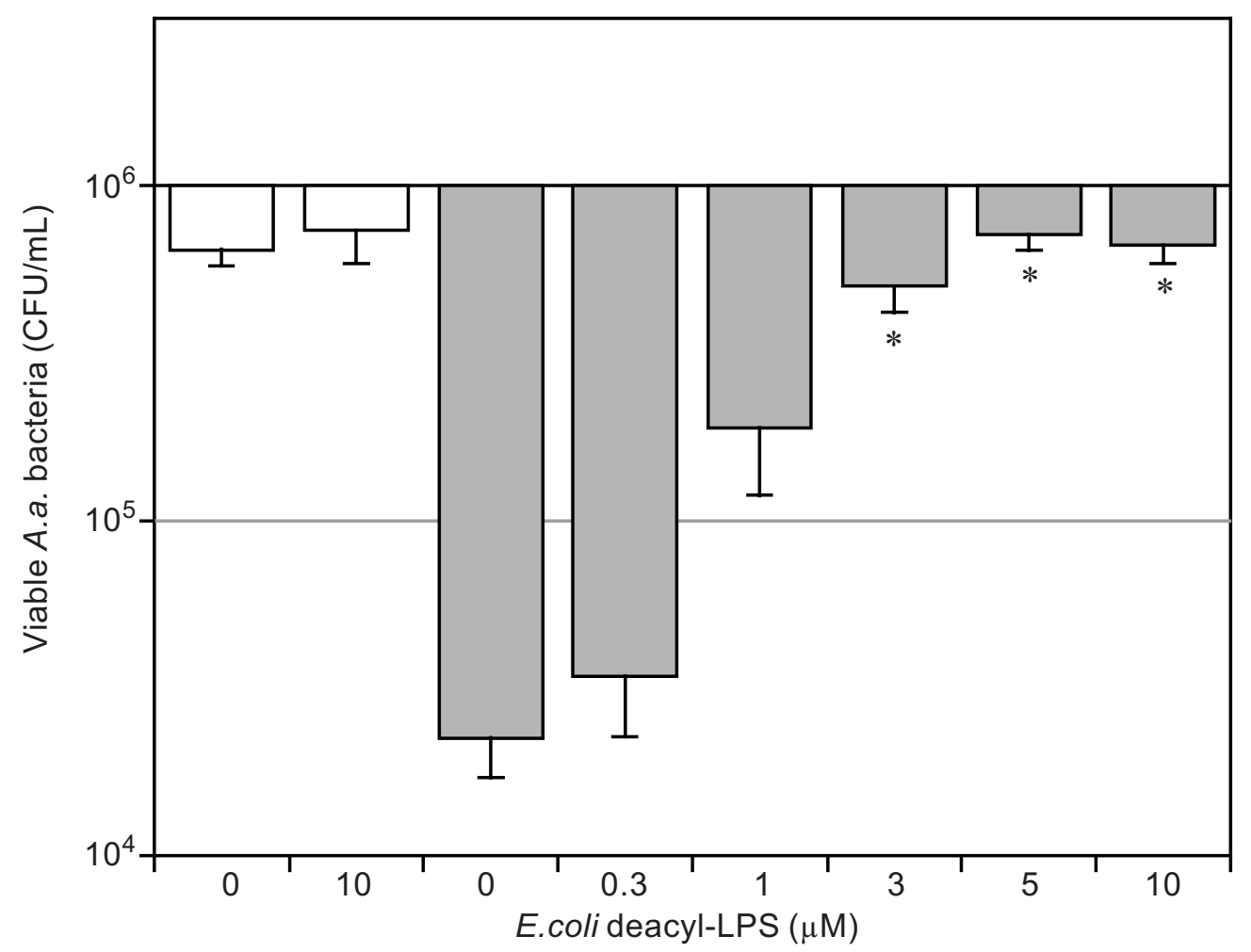

Conditions

Viable bacteria $\left(10^{6} \mathrm{CFU} / \mathrm{ml}\right)$

S.E.

n P value

\begin{tabular}{lllll}
\hline Control $\left(2 \mathrm{~h}, 37^{\circ} \mathrm{C}\right)$ & 0.644 & 0.069 & 8 & - \\
$10 \mu \mathrm{M}$ deacyl-LPS & 0.735 & 0.147 & 4 & - \\
$5 \mu \mathrm{M}$ HBD-3 & 0.022 & 0.005 & 8 & - \\
$5 \mu \mathrm{M}$ HBD-3 $+0.3 \mu \mathrm{M}$ deacyl-LPS & 0.034 & 0.012 & 4 & 1.0 \\
$5 \mu \mathrm{M}$ HBD-3 $+1 \mu \mathrm{M}$ deacyl-LPS & 0.189 & 0.070 & 4 & 1.0 \\
$5 \mu \mathrm{M}$ HBD-3 $+3 \mu \mathrm{M}$ deacyl-LPS & 0.502 & 0.083 & 4 & $0.004 *^{*}$ \\
$5 \mu \mathrm{M}$ HBD-3 $+5 \mu \mathrm{M}$ deacyl-LPS & 0.715 & 0.073 & 4 & $<0.0001 *$ \\
$5 \mu \mathrm{M}$ HBD-3 $+10 \mu \mathrm{M}$ deacyl-LPS & 0.662 & 0.072 & 4 & $<0.0001 *$ \\
\hline
\end{tabular}

Figure 4.18. Deacyl-LPS blocks HBD-3 killing of $\boldsymbol{A} . \boldsymbol{a}$.

A.a. bacteria $\left(10^{6} / \mathrm{ml}\right)$ with 0 or $10 \mu \mathrm{M}$ deacyl-LPS were incubated $2 \mathrm{~h}$ at $37^{\circ} \mathrm{C}$ in buffer without nutrients then diluted and plated (white bars). Alternatively, the bacteria were incubated with $5 \mu \mathrm{M}$ HBD-3 and various levels of deacyl-LPS (gray bars).

* Significantly different from the value with HBD-3 alone. 


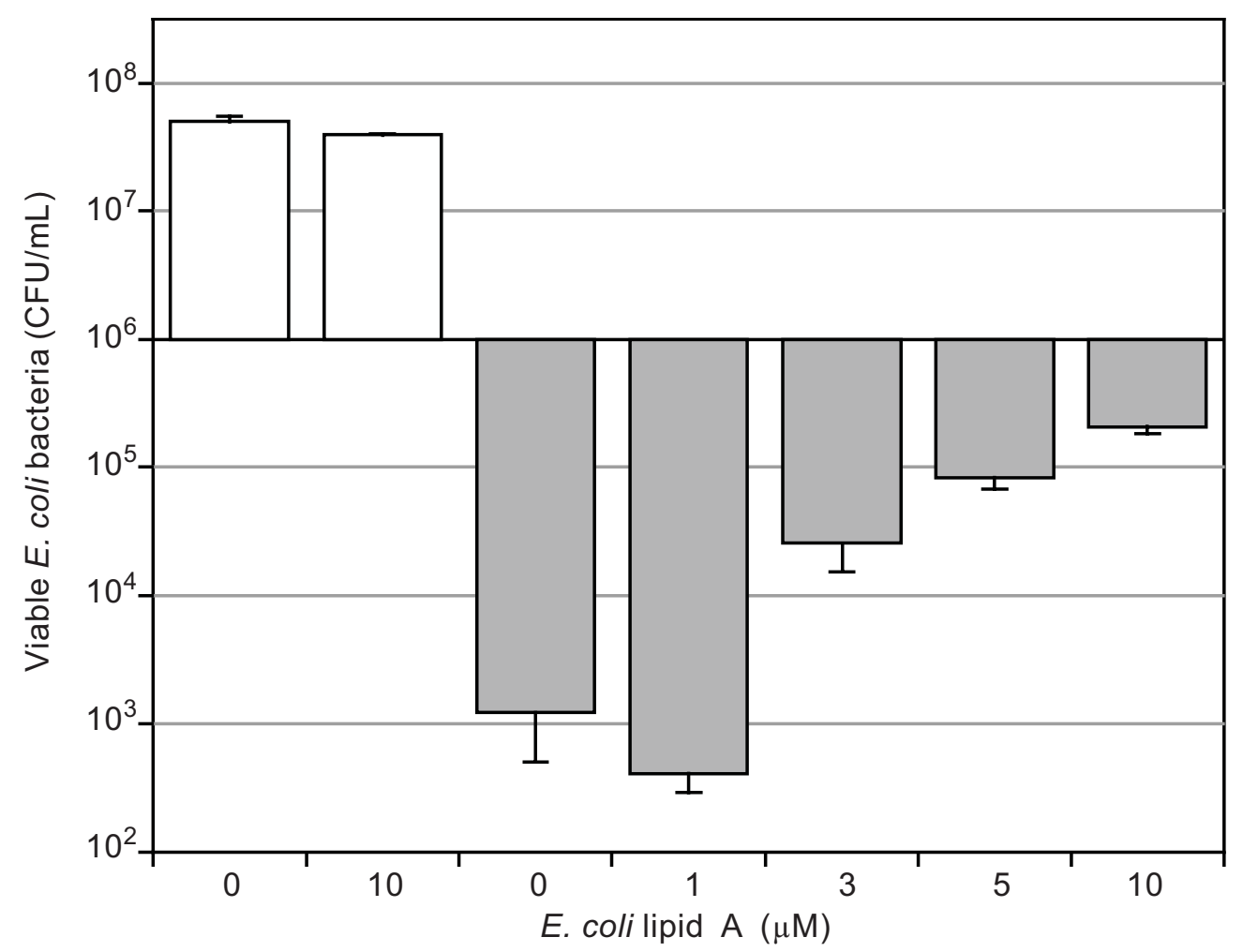

Conditions

Viable bacteria $\left(10^{6} \mathrm{CFU} / \mathrm{ml}\right)$

S.E.

n P value

\begin{tabular}{lrrrr}
\hline Control $\left(4 \mathrm{~h}, 37^{\circ} \mathrm{C}\right)$ & 50.294 & 4.433 & 8 & - \\
$10 \mu \mathrm{M}$ lipid A & 39.262 & 0.735 & 4 & - \\
$5 \mu \mathrm{M}$ HBD-3 & 0.001 & 0.001 & 8 & - \\
$5 \mu \mathrm{M} \mathrm{HBD}-3+1 \mu \mathrm{M}$ lipid A & 0.000 & 0.000 & 4 & 1.0 \\
$5 \mu \mathrm{M} \mathrm{HBD}-3+3 \mu \mathrm{M}$ lipid A & 0.026 & 0.010 & 4 & 1.0 \\
$5 \mu \mathrm{M} \mathrm{HBD}-3+5 \mu \mathrm{M}$ lipid A & 0.083 & 0.016 & 4 & 1.0 \\
$5 \mu \mathrm{M}$ HBD-3 $+10 \mu \mathrm{M}$ lipid A & 0.207 & 0.024 & 4 & 1.0 \\
\hline
\end{tabular}

Figure 4.19. Lipid A does not block HBD-3 killing of $E$. coli

E. coli bacteria $\left(10^{6} / \mathrm{ml}\right)$ with 0 or $10 \mu \mathrm{M}$ lipid A were incubated $4 \mathrm{~h}$ at $37^{\circ} \mathrm{C}$ in dilute culture medium then diluted and plated (white bars). Alternatively, the bacteria were incubated with $5 \mu \mathrm{M}$ HBD-3 and various levels of lipid A (gray bars). 


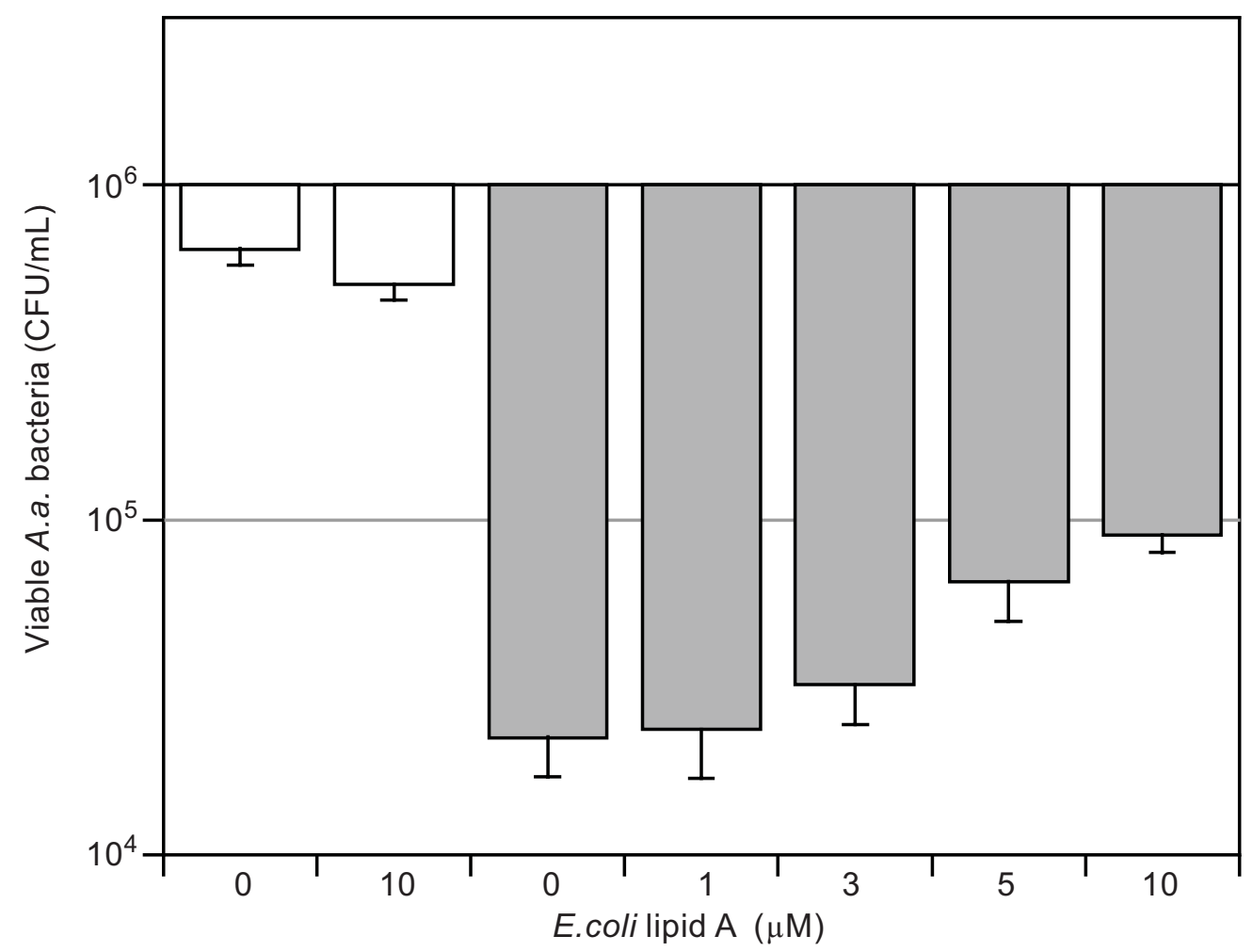

Conditions Viable bacteria
$\left(10^{6} \mathrm{CFU} / \mathrm{ml}\right)$

S.E.

n P value

\begin{tabular}{lllll}
\hline Control $\left(2 \mathrm{~h}, 37^{\circ} \mathrm{C}\right)$ & 0.644 & 0.069 & 8 & - \\
$10 \mu \mathrm{M}$ lipid A & 0.504 & 0.049 & 4 & - \\
$5 \mu \mathrm{M}$ HBD-3 & 0.022 & 0.005 & 8 & - \\
$5 \mu \mathrm{M}$ HBD-3 $+1 \mu \mathrm{M}$ lipid A & 0.024 & 0.007 & 4 & 1.0 \\
$5 \mu \mathrm{M}$ HBD-3 $+3 \mu \mathrm{M}$ lipid A & 0.032 & 0.008 & 4 & 1.0 \\
$5 \mu \mathrm{M}$ HBD-3 $+5 \mu \mathrm{M}$ lipid A & 0.066 & 0.016 & 4 & 1.0 \\
$5 \mu \mathrm{M}$ HBD-3 $+10 \mu \mathrm{M}$ lipid A & 0.090 & 0.010 & 4 & 1.0 \\
\hline
\end{tabular}

Figure 4.20. Lipid A does not block HBD-3 killing of $\boldsymbol{A}$. $\boldsymbol{a}$.

A.a. bacteria $\left(10^{6} / \mathrm{ml}\right)$ with 0 or $10 \mu \mathrm{M}$ lipid A were incubated $2 \mathrm{~h}$ at $37^{\circ} \mathrm{C}$ in buffer without nutrients then diluted and plated (white bars). Alternatively, the bacteria were incubated with $5 \mu \mathrm{M}$ HBD-3 and various levels of lipid A(gray bars). 
concentrations. Lipid A alone also had no effect on growth or viability of the bacteria. These results show the fatty acids of lipid A are not the site where HBD-3 binds to the LPS molecule. 


\section{CHAPTER 5. DISCUSSION}

\section{Effect of Assay Conditions on Activity of HBD-3 and HNP-1}

Previous studies showed that periodontal pathogens were resistant to killing by $\alpha$ defensins HNP 1-3 but were killed by $\beta$-defensins HBD 1-3. In those studies, $\alpha$ - and $\beta$ defensins were assayed under different conditions. Bacteria were incubated with $\alpha$ defensins in dilute growth medium, while incubations with $\beta$-defensins were in low ionic strength buffer without nutrients. Our study compared killing of A.a. and E. coli by HNP1 and HBD-3 under the two sets of conditions. We found that A.a. was resistant to HNP1 and killed by HBD-3 regardless of the assay conditions.

Our results confirm studies indicating that A.a. is killed by HBD-3 and other human $\beta$-defensins. The presence or absence of nutrients had little effect on activity, or lack of activity, of HNP-1 and HBD-3 against A.a. There was, however, a big effect on activity against $E$. coli. Both HNP-1 and HBD-3 killed $E$. coli, and both were more effective when assayed in the presence of nutrients. As expected based on studies by Ganz et al. (3), HNP-1 killed E. coli only in the presence of nutrients. We found that HBD-3 killed $E$. coli in the absence of nutrients but was more effective when nutrients were present.

Further studies are needed to confirm that all periodontal pathogens are resistant to human $\alpha$-defensins and sensitive to human $\beta$-defensins. Other strains of A.a. as well as other periodontal pathogens should be tested.

At least one periodontal pathogen, Treponema denticola, was reported to be relatively resistant to killing by human $\beta$-defensins (78). Therefore, some important periodontal pathogens may be resistant to human $\beta$-defensins. Further studies are needed to examine the ability of $\beta$-defensins to kill periodontal pathogens other than A.a., P.g., P.i. and F.n.

\section{Role of HBD-3 N- and C-terminal Regions in Antimicrobial Activity}

Compared with HNP-1, HBD-3 has additional amino acid residues at the Nterminus and $\mathrm{C}$-terminus. To determine if these additional residues account for HBD-3 activity against $A$.a., we measured the activity of synthetic peptides CHRG07 and CHRG01. These peptides correspond to the first 17 amino acid residues and the last 14 amino acids residues of HBD-3, with serine substituted for cysteine.

The CHRG07 peptide, derived from the N-terminal region of HBD-3, with four hydrophobic residues and four cationic residues, was equal to HBD-3 in activity against A.a. on a molar basis. Therefore, the N-terminal region of HBD-3 accounts for HBD-3 
activity against $A$.a. Our results are consistent with studies $(56,60)$ that found cysteine residues and disulfide bonds were not required for HBD-3 activity in vitro.

HBD-3 has a much greater charge $(+11)$ than any of the human neutrophil $\alpha-$ defensins $(+2$ or +3$)$, but charge alone can't account for the greater activity of HBD-3 against A.a. CHRG07 has a charge of only +4 but is as active as HBD-3 against A.a. CHRG01 has a charge of +8 but is much less active than CHRG07 or HBD-3 against $A$.a. Instead, hydrophobic residues or a combination of hydrophobic and cationic residues appear important for activity against A.a. Y4. CHRG01 has no hydrophobic residues. Further studies with other strains of $A . a$. and other periodontal pathogens are needed to determine whether the mixture of hydrophobic and cationic residues in CHRG07 is always more effective than the more cationic CHRG01.

Further studies could also try to determine the smallest part of HBD-3 that has activity equal to HBD-3 against $A$.a. CHRG07, with three hydrophobic residues among the first six N-terminal residues and three cationic residues among the last six C-terminal residues, has a structure like that of a small $\beta$-defensin without disulfides. Further studies could determine whether a small peptide with three hydrophobic residues linked to three cationic residues would be as active as HBD-3 against $A$. $a$.

As a control, we also measured killing of $E$. coli by HBD-3 and the N-terminal and C-terminal peptides CHRG07 and CHRG01. Our results with E. coli are different from those reported by Hoover et al. (60). It was reported that CHRG01 was much more effective than CHRG07 or HBD-3 against E. coli. Concentrations that killed $90 \%$ of the E. coli bacteria were 6, 19, and $1 \mu \mathrm{g} / \mathrm{mL}$ for HBD-3, CHRG07 and CHRG01, respectively. These levels correspond to $1.2,9.6$, and $0.6 \mu \mathrm{M}$. We found CHRG07 and HBD-3 were equal in activity against $E$. coli, and CHRG01 was less effective than CHRG07 or HBD-3.

There are a number of possible reasons for these differences in results. There may be a strain-selective difference in activity against $E$. coli. Hoover et al. (60) used $E$. coli ATCC 25922, and we used E. coli ML-35 (ATCC 43827). The assay conditions for the studies were similar, but there were differences. Bacteria were grown to mid-logarithmic phase in the study by Hoover et al. (60), and the bacteria were not washed before dilution into the assay medium. We used washed bacteria from the early stationary phase and incubated $4 \mathrm{~h}$ rather than $3 \mathrm{~h}$. Finally, although we had the CHRG07 and CHRG01 sequences synthesized as specified by Hoover et al. (60), the peptides were synthesized at different times in different laboratories. Side-by-side comparison of their preparations and ours would be needed to determine whether they have equal activity. Further studies with additional $E$. coli strains would also be needed to determine which peptide is usually more effective against $E$. coli.

Hoover et al. (60) also tested CHGR07 and CHRG01 against another gramnegative bacterium (Pseudomonas aeruginosa), two gram-positive bacteria (Staphylococcus aureus and Enterococcus faecium) and the fungus C. albicans. It was 
reported that CHRG07 with a mixture of hydrophobic and cationic amino acids was more effective than the highly cationic CHRG01 against all of these organisms. The effect was most pronounced for the gram-positive organisms and C. albicans. These results are more consistent with our results with both A.a. and E. coli.

Some studies report that HBD-3 antimicrobial activity is less subject to interference by physiologic levels of salt and divalent cations compared with the activity of $\alpha$-defensins (e.g. 9,6,79). The high positive charge of HBD-3 may be responsible for decreased interference by salt. High salt disrupts electrostatic interactions between positive and negative charges such as those involved in binding of cationic defensin peptides to anionic microbial components.

Further studies are needed to determine whether $\mathrm{CHRG07}$ would become less effective than HBD-3 at high salt concentrations because it has a smaller positive charge. Studies with CHRG01 might also find that it is more resistant to interference by salt because of its high positive charge.

\section{Binding of HBD-3 to LPS}

Our third objective was to determine if HBD-3 binds to LPS purified from E. coli and A.a. LPS on the surface of gram-negative bacteria might act as the receptor for defensin binding. Our results show that HBD-3 does bind to LPS and that one molecule of HBD-3 binds to one molecule of LPS. Results were similar with LPS from A.a. or $E$. coli, indicating that HBD-3 binds equally well to E. coli and A.a. LPS, despite the small differences in LPS structure between these organisms.

\section{Role of Lipid A in HBD-3 Binding to LPS}

Although HBD-3 binds to LPS and the hydrophobic residues of HBD-3 appear to be important for activity against A.a., there was no evidence for hydrophobic binding of HBD-3 to LPS. Deacyl-LPS without the hydrophobic fatty acids bound HBD-3 and blocked activity. Deacyl-LPS was as effective as LPS, indicating that the fatty acids were not required for binding of HBD-3 to LPS. Lipid A did not block HBD-3 activity, indicating that HBD-3 does not bind to lipid A.

Further studies could try to determine whether HBD-3 binds like a lectin to carbohydrate of the LPS oligosaccharide and core or whether cationic amino acid residues of HBD-3 bind electrostatically to negative-charged phosphate groups of the LPS core.

Hydrophobic amino acids of HBD-3 are important for antimicrobial activity against A.a. but must be involved in some process other than binding to LPS. Further studies could determine if HBD-3 binds to membrane phospholipids or hydrophobic membrane proteins or inserts into bacterial membranes. 


\section{General Significance of This Study}

HBD-3 is effective against many periodontal pathogens, but periodontal disease remains a significant problem affecting at least $30 \%$ of the population. Therefore, HBD-3 does not protect everybody against periodontal disease. HBD-3 levels may not be adequate to protect the tissues when the microbial burden is high, or HBD-3 may be expressed in deep layers of the epithelium and may not prevent bacterial penetration through the surface layers. HBD-3 may also be destroyed by some periodontal pathogens. Proteolytic enzymes called gingipains produced by $P$. gingivalis have been reported to destroy HBD-3 (79). There may also be differences in the amounts of HBD-3 expressed by different individuals or by the same individual at different times. Most of the genes for defensins are clustered on chromosome 8 and the number of copies of these genes is subject to individual variation (11). Defensin genes have also been reported to have a high rate of single nucleotide polymorphisms $(80,81)$. A variation in an untranslated region of the gene for HBD-1 was reported to be associated with protection from oral candidiasis (82). The same gene variant was reported to influence the level of HBD-1 and HBD-3 mRNA expression by oral keratinocytes.

Small synthetic peptides with good activity against periodontal pathogens might be useful as topical agents to prevent or treat periodontal disease. Candidate peptides with good antimicrobial activity would also need to be tested to be sure they would not be pro-inflammatory or easily degraded by proteases. Small peptides cost less to make, are more easily purified than larger peptides or proteins and are less likely to be contaminated with endotoxin. Small peptides are also less likely to provoke an immune reaction. Further studies may lead to the development of clinically-useful synthetic peptides.

\section{Overall Significance}

Gingival and periodontal diseases, in their various forms have afflicted mankind since the start of history. Periodontitis is very common and is widely regarded as the second most common disease worldwide after dental decay. In the United States, 30-50\% of the population has periodontitis but only about $10 \%$ has severe forms. Periodontitis appears to be more prevalent in economically disadvantaged populations or regions. In the third National Health and Nutrition Examination Survey (NHANES III, 1984-94), $50 \%$ of non-institutionalized adult Americans were found to have gingivitis on at least three teeth.

Periodontitis is a gram-negative infection resulting in severe inflammation with the potential for intravascular dissemination of microorganisms and their products throughout the body. Periodontitis is linked to many systemic health problems including atherosclerosis and diabetes. New approaches are needed to prevent and treat disease. 
Understanding why human leukocyte $\alpha$-defensins are ineffective against periodontal pathogens such as A.a., while human epithelial cell $\beta$-defensins are effective will help to understand the disease process and may lead to new approaches to treat and prevent periodontal disease. 


\section{LIST OF REFERENCES}

1. Page, R.C., Sims, T.J., Geissler, F., Altman, L.C., Baab, D.A. (1985) Defective neutrophil and monocyte motility in patients with early onset periodontitis. Infect Immun 47:169-75.

2. Hart, T.C., Kornman, K.S. (1997) Genetic factors in the pathogenesis of periodontitis. Periodontol 2000 14:202-215.

3. Ganz, T., Selsted, M.E., Szklarek, D., Harwig, S.S., Daher, K., Bainton, D.F., Lehrer, R.I. (1985) Defensins: natural peptide antibiotics of human neutrophils. $J$ Clin Invest 76:1427-1435.

4. Wilde, C.G., Griffith, J.E., Marra, M.N., Snable, J.L., Scott, R.W. (1989)

Purification and characterization of human neutrophil peptide 4, a novel member of the defensin family. J Biol Chem 264:11200-11203.

5. Weinberg, A., Krisanaprakornkit, S., Dale, B.A. (1998) Epithelial antimicrobial peptides: review and significance for oral applications. Crit Rev Oral Biol Med 9:399-414.

6. Chung, W.O., Dommisch, H., Yin, L., Dale, B.A. (2007) Expression of defensins in gingiva and their role in periodontal health and disease. Curr Pharm Des 13:30733083.

7. Diamond, G., Beckloff, N., Weinberg, A. Kisich, K.O. (2009) The roles of antimicrobial peptides in innate host defense. Curr Pharm Des 15:2377-2392.

8. Lu, Q. Jin, L., Darveau, R.P., Samaranayake, L.P. (2004) Expression of human betadefensins-1 and -2 in unresolved chronic periodontitis. J Periodontal Res 39:221227.

9. Harder, J., Bartels, J., Christophers, E., Schroder, J.M. (2001) Isolation and characterization of human beta-defensin-3, a novel human inducible peptide antibiotic. J Biol Chem 276:5707-5713.

10. Garcia, J.R., Jaumann, F., Schulz, S., Krause, A., Rodriguez-Jimenez, J., Forssmann, U., Adermann, K., Kluver, E., Vogelmeier, C., Becker, D., Hedrich, R., Forssmann, W.G., Bals, R. (2001) Identification of a novel, multifunctional betadefensin (human beta-defensin 3) with specific antimicrobial activity. Its interaction with plasma membranes of Xenopus oocytes and the induction of macrophage chemoattraction. Cell Tissue Res 306:257-264. 
11. Auvynet, C., Rosenstein, Y. (2009) Multifunctional host defense peptides: antimicrobial peptides, the small yet big players in innate and adaptive immunity. FEBS J 276:6497-6508.

12. Schibli, D.J., Hunter, H.N., Aseyev, V., Starner, T.D., Wiencek, J.M., McCray, P.B. Jr., Tack, B.F., Vogel, H.J. (2002) The solution structures of the human betadefensins lead to a better understanding of the potent bactericidal activity of HBD3 against Staphylococcus aureus. J Biol Chem 277:8279-8289.

13. Guaní-Guerra, E., Santos-Mendoza, T., Lugo-Reyes, S.O., Terán, L.M. (2010) Antimicrobial peptides: general overview and clinical implications in human health and disease. Clin Immunol 135:1-11.

14. Wiesner, J., Vilcinskas, A. (2010) Antimicrobial peptides: the ancient arm of the human immune system. Virulence 1:440-464.

15. Lehrer, R.I., Ganz, T. (1996) Endogenous vertebrate antibiotics: defensins, protegrins, and other cysteine-rich antimicrobial peptides. Ann N Y Acad Sci 797:228-239.

16. Ganz, T. (2003) Defensins: antimicrobial peptides of innate immunity. Nat Rev Immun 3:710-720.

17. Maisetta, G., Batoni, G., Esin, S., Luperini, F., Pardini, M., Bottai, D., Florio, W., Giuca, M.R., Gabriele, M., Campa, M. (2003) Activity of human beta-defensin 3 alone or combined with other antimicrobial agents against oral bacteria. Antimicrob Agents Chemother 47:3349-3351.

18. Midorikawa, K., Ouhara, K., Komatsuzawa, H., Kawai, T., Yamada, S., Fujiwara, T., Yamazaki, K., Sayama, K., Taubman, M.A., Kurihara, H., Hashimoto, K., Sugai, M. (2003) Staphylococcus aureus susceptibility to innate antimicrobial peptides, beta-defensins and CAP18, expressed by human keratinocytes. Infect Immun 71:3730-3739.

19. Joly, S., Maze, C., McCray, P.B. Jr., Guthmiller, J.M. (2004) Human beta-defensins 2 and 3 demonstrate strain-selective activity against oral microorganisms. J Clin Microbiol 42:1024-1029.

20. Ouhara, K., Komatsuzawa, H., Yamada, S., Shiba, H., Fujiwara, T., Ohara, M., Sayama, K., Hashimoto, K., Kurihara, H., Sugai, M. (2005) Susceptibilities of periodontopathogenic and cariogenic bacteria to antibacterial peptides, \{beta $\}$ defensins and LL37, produced by human epithelial cells. J Antimicrob Chemother 55:888-996. 
21. Ji, S., Hyun, J., Park, E., Lee, B.L., Kim, K.K., Choi, Y. (2007) Susceptibility of various oral bacteria to antimicrobial peptides and to phagocytosis by neutrophils. $J$ Periodontal Res 42:410-419.

22. Martin, E., Ganz, T., Lehrer, R.I. (1995) Defensins and other endogenous peptide antibiotics of vertebrates. J Leukoc Biol 58:128-136.

23. Dale, B.A., Krisanaprakornkit, S. (2001) Defensin antimicrobial peptides in the oral cavity. J Oral Pathol Med 30:321-327.

24. Bosshardt, D.D., Lang, N.P. (2005) The junctional epithelium: from health to disease. J Dent Res 2005 84:9-20.

25. Dale, B.A., Kimball, J.R., Krisanaprakornkit, S., Roberts, F., Robinovitch, M., O'Neal R., Valore, E.V., Ganz, T., Anderson, G.M., Weinberg, A. (2001) Localized antimicrobial peptide expression in human gingiva. J Periodontal Res 6:285-294.

26. Dale, B.A., Fredericks, L.P. (2005) Antimicrobial peptides in the oral environment: expression and function in health and disease. Curr Issues Mol Biol 7:119-133.

27. Goebel, C., Mackay, L.G., Vickers, E.R., Mather, L.E. (2000) Determination of defensin HNP-1, HNP-2, and HNP-3 in human saliva by using LC/MS. Peptides 21:757-765.

28. Mizukawa, N., Sugiyama, K., Ueno, T., Mishima, K., Takagi, S., Sugahara, T. (1999) Defensin-1, an antimicrobial peptide present in the saliva of patients with oral diseases. Oral Dis 5:139-142.

29. Pütsep, K., Carlsson, G., Boman, H.G., Andersson, M. (2002) Deficiency of antibacterial peptides in patients with morbus Kostmann: an observation study. Lancet 360:1144-1149.

30. Tao, R., Jurevic, R.J., Coulton, K.K., Tsutsui, M.T., Roberts, M.C., Kimball, J.R., Wells, N., Berndt, J., Dale, B.A. (2005) Salivary antimicrobial peptide expression and dental caries experience in children. Antimicrob Agents Chemother 49:38833888 .

31. Dale, B.A., Tao, R., Kimball, J.R., Jurevic, R.J. (2006) Oral antimicrobial peptides and biological control of caries. BMC Oral Health 6 Suppl 1:S13.

32. Fanali, C., Inzitari, R., Cabras, T., Pisano, E., Castagnola, M., Celletti, R., Manni, A., Messana, I. (2008) Alpha-defensin levels in whole saliva of totally edentulous subjects. Int J Immunopathol Pharmacol 21:845-849. 
33. McKay, M.S., Olson, E., Hesla, M.A., Panyutich, A., Ganz, T., Perkins, S., Rossomando, E.F. (1999) Immunomagnetic recovery of human neutrophil defensins from the human gingival crevice. Oral Microbiol Immunol 14:190-193.

34. Lundy, F.T., Orr, D.F., Shaw, C., Lamey, P.J., Linden, G.J. (2005) Detection of individual human neutrophil alpha-defensins (human neutrophil peptides 1, 2 and 3) in unfractionated gingival crevicular fluid - a MALDI-MS approach. Mol Immunol 42:575-579.

35. Bostanci, N., Heywood, W., Mills, K., Parkar, M., Nibali, L., Donos, N. (2010) Application of label-free absolute quantitative proteomics in human gingival crevicular fluid by LC/MS ${ }^{\mathrm{E}}$ (gingival exudatome). J Proteome Res 9:2191-2199.

36. Ngo, L.H., Veith, P.D., Chen, Y.Y., Chen, D., Darby, I.B., Reynolds, E.C. (2010) Mass spectrometric analyses of peptides and proteins in human gingival crevicular fluid. J Proteome Res 9:1683-1693.

37. Puklo, M., Guentsch, A., Hiemstra, P.S., Eick, S., Potempa, J. (2008) Analysis of neutrophil-derived antimicrobial peptides in gingival crevicular fluid suggests importance of cathelicidin LL-37 in the innate immune response against periodontogenic bacteria. Oral Microbiol Immunol 23:328-335.

38. Mathews, M., Jia, H.P., Guthmiller, J.M., Losh, G., Graham, S., Johnson, G.K., Tack, B.F., McCray, P.B. Jr. (1999) Production of beta-defensin antimicrobial peptides by the oral mucosa and salivary glands. Infect Immun 67:2740-2745.

39. Lu, Q., Samaranayake, L.P., Darveau, R.P., Jin, L. (2005) Expression of human beta-defensin-3 in gingival epithelia. J Periodontal Res 40:474-481.

40. Dommisch, H., Açil, Y., Dunsche, A., Winter, J., Jepsen, S. (2005) Differential gene expression of human beta-defensins (hBD-1, -2, -3) in inflammatory gingival diseases. Oral Microbiol Immunol 20:186-190.

41. Feucht, E.C., DeSanti, C.L., Weinberg, A. (2003) Selective induction of human beta-defensin mRNAs by Actinobacillus actinomycetemcomitans in primary and immortalized oral epithelial cells. Oral Microbiol Immunol 18:359-363.

42. Diamond, D.L., Kimball, J.R., Krisanaprakornkit, S., Ganz, T., Dale, B.A. (2001) Detection of beta-defensins secreted by human oral epithelial cells. J Immunol Methods 256:65-76.

43. Brancatisano, F.L., Maisetta, G., Barsotti, F., Esin, S., Miceli, M., Gabriele, M., Giuca, M.R., Campa, M., Batoni, G. (2011) Reduced human beta defensin 3 in individuals with periodontal disease. J Dent Res 90:241-245. 
44. Genco, R., Kornman, K., Williams, R., Offenbacher, S., Zambon J.J., Ishikawa, I., Listgarten, M.A., Michalowicz, B.S., Page, R., Schenckein, H. Slots, J., Socransky, S.S., Van Dyke, T.E., Consensus report (1996) Periodontal diseases: pathogenesis and microbial factors. Ann Periodontol 1:926-932.

45. Lovegrove, J.M. (2004) Dental plaque revisited: bacteria associated with periodontal disease. JN Z Soc Periodontol 87:7-21.

46. Picolos, D.K., Lerche-Sehm, J., Abron. A., Fine, J.B., Pappapanou, P.N. (2005) Infection patterns in chronic and aggressive periodontitis. J Clin Periodontol 32:1055-1061.

47. Miyasaki, K.T., Bodeau, A.L., Ganz, T., Selsted, M.E., Lehrer, R.I. (1990) In vitro sensitivity of oral, gram-negative, facultative bacteria to the bactericidal activity of human neutrophil defensins. Infect Immun 58:3934-3940.

48. Miyasaki, K.T., Iofel, R., Lehrer, R.I. (1997) Sensitivity of periodontal pathogens to the bactericidal activity of synthetic protegrins, antibiotic peptides derived from porcine leukocytes. $J$ Dent Res 76:1453-1459.

49. Raj, P.A,. Antonyraj, K.J., Karunakaran, T. (2000) Large-scale synthesis and functional elements for the antimicrobial activity of defensins. Biochem J347 Pt 3:633-641.

50. Lee, S.H., Jun, H.K., Lee, H.R., Chung, C.P., Choi, B.K. (2010) Antibacterial and lipopolysaccharide (LPS)-neutralising activity of human cationic antimicrobial peptides against periodontopathogens. Int J Antimicrob Agents 35:138-145.

51. Miyasaki, K.T. (1991) The neutrophil: mechanisms of controlling periodontal bacteria. J Periodontol 62:761-774.

52. Miyasaki, K.T, Lehrer, R.I. (1998) Beta-sheet antibiotic peptides as potential dental therapeutics. Int J Antimicrob Agents 9:269-80.

53. Miyasaki, K.T., Bodeau, A.L., Selsted, M.E., Ganz, T., Lehrer, R.I. (1990) Killing of oral, gram-negative, facultative bacteria by the rabbit defensin, NP-1. Oral Microbiol Immunol 5:315-319.

54. Komatsuzawa, H., Ouhara, K., Kawai, T., Yamada, S., Fujiwara, T., Shiba, H., Kurihara, H., Taubman, M.A., Sugai M. (2007) Susceptibility of periodontopathogenic and cariogenic bacteria to defensins and potential therapeutic use of defensins in oral diseases. Curr Pharm Des 13:3084-3095.

55. Raj, P.A., Dentino, A.R. (2002) Current status of defensins and their role in innate and adaptive immunity. FEMS Microbiol Lett 206:9-18. 
56. Wu, Z., Hoover, D.M., Yang, D., Boulègue, C., Santamaria, F., Oppenheim, J.J., Lubkowski, J., Lu, W. (2003) Engineering disulfide bridges to dissect antimicrobial and chemotactic activities of human beta-defensin 3. Proc Natl Acad Sci U S A 100:8880-8885.

57. Maemoto, A., Qu, X., Rosengren, K.J., Tanabe, H., Henschen-Edman, A., Craik, D.J., Ouellette, A.J. (2004) Functional analysis of the alpha-defensin disulfide array in mouse cryptdin-4. J Biol Chem 279:44188-44196.

58. Selsted, M.E., Ouellette, A.J. (2005) Mammalian defensins in the antimicrobial immune response. Nat Immunol 6:551-557.

59. Klüver, E., Schulz-Maronde, S., Scheid, S., Meyer, B., Forssmann, W.G., Adermann, K. (2005) Structure-activity relation of human beta-defensin 3: influence of disulfide bonds and cysteine substitution on antimicrobial activity and cytotoxicity. Biochemistry 44:9804-9816.

60. Hoover, D.M., Wu, Z., Tucker, K., Lu, W., Lubkowski, J. (2003) Antimicrobial characterization of human beta-defensin 3 derivatives. Antimicrob Agents Chemother 47:2804-2809.

61. Xie, C., Prahl, A., Ericksen, B., Wu, Z., Zeng, P., Li, X., Lu, W.Y., Lubkowski, J., Lu, W. (2005) Reconstruction of the conserved beta-bulge in mammalian defensins using D-amino acids. J Biol Chem 280:32921-32929.

62. Raetz, C.R. (1990) Biochemistry of endotoxins. Annu Rev Biochem 59:129-170.

63. Raetz, C.R., Whitfield, C. (2002) Lipopolysaccharide endotoxins. Annu Rev Biochem 71:635-700.

64. Rietschel, E.T., Kirikae, T., Schade, F.U., Mamat, U., Schmidt, G., Loppnow, H., Ulmer, A.J., Zähringer, U., Seydel, U., DiPadova, F., Schreier, M., Brade, H. (1994) Bacterial endotoxin: molecular relationships of structure to activity and function. FASEB J. 8:217-225.

65. Nikaido, H., Vaara, M. (1985) Molecular basis of bacterial outer membrane permeability. Microbiol Rev 49:1-32.

66. Loppnow, H., Brade, H., Dürrbaum, I., Dinarello, C.A., Kusumoto, S., Rietschel, E.T., Flad, H.D. (1989) IL-1 induction-capacity of defined lipopolysaccharide partial structures. J Immunol 142:3229-3238.

67. Beutler, B. (1988) The presence of cachectin/tumor necrosis factor in human disease states. Am J Med 85:287-288. 
68. Galanos, C., Lüderitz, O., Rietschel, E.T., Westphal, O., Brade, H., Brade, L., Freudenberg, M., Schade, U., Imoto, M., Yoshimura, H., Kusumoto, S., Shiba, T. (1985) Synthetic and natural Escherichia coli free lipid A express identical endotoxic activities. Eur J Biochem 148:1-5.

69. Lowry, O.H., Rosebrough, N.J., Farr, A.L., Randall, R.J. (1951) Protein measurement with the Folin phenol reagent. J Biol Chem 193:265-275.

70. Millar, S.J., Goldstein, E.G., Levine, M.J., Hausmann, E. (1986) Modulation of bone metabolism by two chemically distinct lipopolysaccharide fractions from Bacteroides gingivalis. Infect Immun 51:302-306.

71. Mansheim, B.J., Onderdonk, A.B., Kasper, D.L. (1978) Immunochemical and biologic studies of the lipopolysaccharide of Bacteroides melaninogenicus subspecies asaccharolyticus. J Immunol 120:72-78.

72. Westphal, O., Jann, K. (1965) Bacterial lipopolysaccharides. Methods in Carbohydrate Chemistry 5:83-91.

73. Ding, H.F., Nakoneczna, I., Hsu, H.S. (1990) Protective immunity induced in mice by detoxified salmonella lipopolysaccharide. J Med Microbiol 31:95-102.

74. Qureshi, N., Takayama, K., Heller, D., Fenselau, C. (1983) Position of ester groups in the lipid A backbone of lipopolysaccharides obtained from Salmonella typhimurium. J Biol Chem 258:12947-12951.

75. Tanamoto, K., Azumi, S., Haishima, Y., Kumada, H., Umemoto, T. (1997) Endotoxic properties of free lipid A from Porphyromonas gingivalis. Microbiology 143:63-71.

76. Davis, B.D., Mingioli, E.S. (1950) Mutants of Escherichia coli requiring methionine or vitamin B12. J Bacteriol 60:17-28.

77. Aurell, C.A., Wistrom, A.O. (1998) Critical aggregation concentrations of gramnegative bacterial lipopolysaccharides. Biochem Biophys Res Commun 253:119123.

78. Brissette, C.A., Lukehart, S.A. (2007) Mechanisms of decreased susceptibility to beta-defensins by Treponema denticola. Infect Immun 75:2307-2315.

79. Maisetta, G., Brancatisano, F.L., Esin, S., Campa, M., Batoni, G. (2011) Gingipains produced by Porphyromonas gingivalis ATCC49417 degrade the human- $\beta$-defensin 3 and affect peptide's antibacterial activity in vitro. Peptides. Feb 16 [Epub ahead of print]. 
80. Taylor, K., Barran, P.E., Dorin, J.R. (2008) Structure-activity relationships in betadefensin peptides. Biopolymers 90:1-7.

81. Hollox, E.J., Barber, J.C., Brookes, A.J., Armour, J.A. (2008) Defensins and the dynamic genome: what we can learn from structural variation at human chromosome band 8p23.1. Genome Res 18:1686-1697.

82. Kalus, A.A., Fredericks, L.P., Hacker, B.M., Dommisch, H., Presland, R.B., Kimball, J.R., Dale, B.A. (2009) Association of a genetic polymorphism (-44 C/G SNP) in the human DEFB1 gene with expression and inducibility of multiple betadefensins in gingival keratinocytes. BMC Oral Health 9:21. 


\section{VITA}

Dr. Norman B. Fine was born in 1981 in Charleston, S.C. He graduated from Charleston Southern University with a Bachelor of Science in Professional Biology. He then received his Doctorate of Dental Medicine degree from The Medical University of South Carolina where he was the representative to the American Dental Education Association. Dr. Fine participated as a teaching assistant in the Departments of Endodontics and Periodontics. He was awarded the John Meador Sneed scholarship for his dedication to patient care and practice ethics. He was on the Academic Deans List and graduated with honors of magna cum laude.

Dr. Fine is completing his specialty training in Periodontology at The University of Tennessee Health Science Center. He is a member of the American Academy of Periodontology, American Dental Association, and Psi Omega Dental Fraternity. He has co-authored an article in The Journal of the Tennessee Dental Association titled "Periodontal and Cardiovascular Diseases: Common Inflammatory Mediators." He will go on to private practice in Greenville, South Carolina. 